Review

\title{
Beryllium Mineralogy of the Kola Peninsula, Russia-A Review
}

\author{
Lyudmila M. Lyalina *, Ekaterina A. Selivanova $₫$, Dmitry R. Zozulya $₫$ and \\ Gregory Yu. Ivanyuk ${ }^{(\mathbb{D}}$
}

Geological Institute, Kola Science Centre, Russian Academy of Sciences, Fersmana 14, 184209 Apatity, Russia; selivanova@geoksc.apatity.ru (E.A.S.); zozulya@geoksc.apatity.ru (D.R.Z.); ivanyuk@geoksc.apatity.ru (G.Y.I.)

* Correspondence: lialina@geoksc.apatity.ru; Tel.: +7-81555-7-96-66

Received: 1 October 2018; Accepted: 21 December 2018; Published: 25 December 2018

check for updates

\begin{abstract}
This paper reviews the available information on the beryllium mineralogy of the different type of occurrences in the Kola Peninsula, northwest Russia. Beryllium mineralization in the region is mainly associated with alkaline and felsic rocks, which differ significantly in petrological, geochemical, mineralogical features and age. In total 28 beryllium minerals are established on the Kola Peninsula up today. Beryl is one of the ore minerals in the differentiated granite pegmatites of the Kolmozerskoe lithium deposit. A large diversity of beryllium minerals occur in the pegmatites and hydrothermal veins formed in the late stages of the Lovozero and Khibiny alkaline massifs. Most of these minerals, as leifite, lovdarite, odintsovite, sphaerobertrandite and tugtupite are rare in other environments and have unique properties. These minerals formed under conditions of extreme alkalinity and their formation was favored by abrupt changes in the alkalinity regimes. Some of minerals, as chrysoberyl in xenoliths of hornfels, genthelvite and unique intergrowth of meliphanite and leucophanite formed in contrasting geochemical fronts between felsic/intermediate and mafic rocks.
\end{abstract}

Keywords: beryllium minerals; chemical composition; mineral data; alkaline rocks; granite; pegmatites; hydrothermal veins; Kola Peninsula

\section{Introduction}

In 2018, 220 years have passed since the discovery of beryllium by the French chemist N.-L. Vauquelin. He made a report "De l'aigue marine, ou béril; et découverte d'une terre nouvelle dans cette pierre" (About the aquamarine or beryl, and discovery of a new earth in this stone) at the National Institute of France on the 14 February 1798 [1,2]. However, beryl and their colored varieties: emerald, aquamarine, and "chrysoberyl" (golden beryl, not the sensu stricto chrysoberyl), were known from much earlier times.

Many branches of contemporary industry use this chemical element due to the unique properties of the beryllium-bearing compounds. Thus, in metallurgy, beryllium is used effectively in alloys in order to increase their strength, hardness, and corrosion resistance. Such additives increase the service life of parts in several times. Alloys with beryllium are incredibly light and heat-resistant, which determines their use in the aerospace industry. Beryllium is indispensable in the nuclear and electronic industry, in the electro- and radiotechnics and many other high-tech industries.

USA is the main producer of beryllium ore from bertrandite-bearing tuff in the Spor Mountain deposit, Utah. Russia plans to resume the mining of beryllium ore (bertrandite-phenakite) in Ermakovsky deposit, Buryatia in 2019. The Russian production of beryllium is planned to be started in 2020 . 
History, properties, distribution, analytical methods of determination, economics, fields of application, mineralogy, petrology, geochemistry and crystal chemistry of beryllium can be found in numerous reviews [3-16].

Beryllium is a rare lithophile element; it is concentrated mainly in felsic and alkaline rocks. The beryllium content in rocks is low, and the average concentration of Be in the Earth's upper crust is $2.1 \mathrm{ppm}$, while in primitive mantle it shows a 30-fold decreasing up to $0.07 \mathrm{ppm}$ Be [17]. Beryllium tends to accumulate in late derivatives of alkaline and felsic rocks, i.e., pegmatites and hydrothermal veins. Due to specific crystal chemistry properties $[6,18]$, there is a significant amount of Be minerals (121 minerals, according to IMA list from March 2018). Discoveries of beryllium minerals are accelerating and 18 new minerals were described since 2010 (IMA list of Minerals, March 2018). Minerals of extremely unusual composition have been defined among them, for example verbierite $\mathrm{BeCr}^{3+}{ }_{2} \mathrm{TiO}_{6}[19]$.

\section{Geological Overview of the Kola Peninsula. Deposit and Occurrences of Beryllium Minerals}

The Kola Peninsula is the northeastern part of the Fennoscandian Shield, the largest representative of the Early Precambrian crystalline basement of the East-European craton. The major structural units and rocks are given in Figure 1. An essential role of alkaline magmatism in the Kola Peninsula should be emphasized [20]. It took place during the formation of the Fennoscandian Shield from the Archean to Paleozoic. Keivy block is formed by the rocks of Archean peralkaline granite magmatism (2.6-2.7 Ga) [21]. The emplacement of Sakharjok nepheline syenite within the Keivy terrane occurred during the final stage of the peralkaline granite magmatismin $(2.6 \mathrm{Ga})$. Alkaline magmatism activity reached the peak during the Paleozoic (350-400 Ma) and gave the world's largest alkaline plutons, Khibiny and Lovozero, and a number of other alkaline-ultrabasic massifs, all of them containing carbonatites [22].

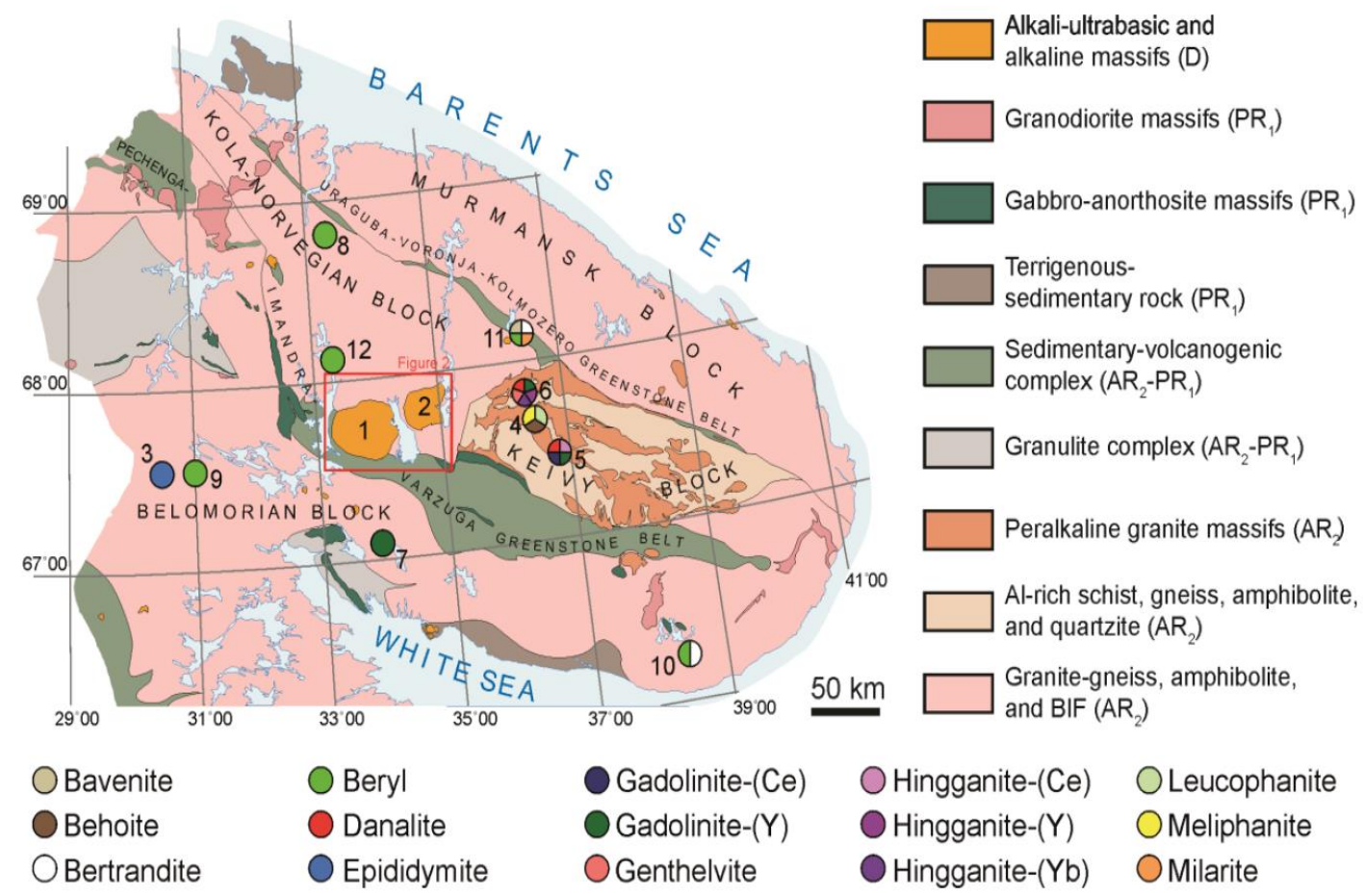

Figure 1. Simplified geological map of the Kola Peninsula (after [22]). The numbers indicate be deposit and occurrences: 1 = Khibiny, $2=$ Lovozero, $3=$ Kovdor, $4=$ Sakharjok, $5=$ El'ozero, $6=$ Keivy, $7=$ Kanozero, 8 = Shongui, 9 = Jona, $10=$ Strel'na, $11=$ Kolmozero-Voronja, $12=$ Olenegorsk. Abbreviations: AR-Archaean, PR-Proterozoic, D-Devonian, BIF-Banded Iron Formation. 
The Uraguba-Kolmozero-Voronja greenstone belt (Figure 1) is composed mainly by Neoarchean basic-intermediate-acid metavolcanic and metasedimentary suites metamorphosed at amphibolite facies. Younger igneous events are represented by voluminous intrusions of plagio-microcline granites and small stocks of tourmaline granites. Six pegmatite fields, comprising Polmostundra, Kolmozero and Vasin-Mylk (Voronja Tundra) ore deposits, with a total ensemble of more than 100 bodies are confined to the Kolmozero-Voronja belt. The pegmatites intrude in amphibolites, metasediments and rarely gabbro-anorthosite and have 50-700 $\mathrm{m}$ long and 10-35 $\mathrm{m}$ in thickness. Quartz-albite-microcline pegmatite bodies are extremely enriched in rare element minerals: spodumene (18-20 vol \%, locally up to $50 \mathrm{vol} \%$ ), tantalite, microlite, beryl, lithiophillite, holmquistite, pollucite, and lepidolite. The Kolmozero-Voronja pegmatites are of complex type, spodumene subtype with $\mathrm{Li}, \mathrm{Cs}, \mathrm{Be}, \mathrm{Ta}$ geochemical specialization and belong to LCT (lithium-cesium-tantalum) family (according to the classification of Černý and Ercit [23]). The overall schematic structure and composition of pegmatites is the following (from contact to central part): (1) aplitic zone of a 1-10 cm width consisting by plagioclase and quartz with minor biotite, tourmaline, apatite, and epidote; (2) granoblastic medium-grained quartz-albite zone of $0.3-5 \mathrm{~m}$ in width with minor and accessory muscovite, microcline, and spodumene; (3) medium-, coarse-grained quartz-albite-spodumene zone with minor and accessory muscovite, apatite, spessartine, beryl, and tantalite; (4) coarse-grained quartz-spodumene blocks and lenses within zone 3 of $0.5-2 \mathrm{~m}$ size with minor euhedral (up to $10 \mathrm{~cm}$ ) muscovite, beryl, tantalite, apatite, spessartine, lithiophilite; (5) quartz-muscovite lenses of $0.1-1 \mathrm{~m}$ length within zone 3 with minor beryl, tantalite, and lithiophilite. The pegmatites crystallized under relatively high pressure (3-4 kbar) with peraluminous S-type granite as the source magma. The ore contains $0.9-1.25$ wt $\%$ of $\mathrm{Li}_{2} \mathrm{O}, 0.37$ wt $\%$ of $\mathrm{Cs}_{2} \mathrm{O}, 0.027-0.053$ wt \% of $\mathrm{BeO}$, $0.004-0.03 \mathrm{wt} \%$ of $\mathrm{Ta}_{2} \mathrm{O}_{5}$ [24]. The grades and estimated resources of Kolmozerskoe lithium deposit within Kolmozero-Voronja belt are comparable to those from giant pegmatite-hosted Li-Ta-Be deposits, i.e., Greenbushes, Wodgina and Mt Cattlin in Australia, Bernic Lake, La Corne and Wekusko in Canada, and North Carolina in USA [25].

The Shongui occurrence in Kolmozero-Voronja belt (Figure 1) is represented by granite pegmatite but published geological data are not available.

The peralkaline granite-syenite complex (named as Keivy alkaline province) is an essential part of the Keivy block (Figure 1). It consists of six large alkali feldspar granite massifs (Western Keivy, Beliye Tundry, Ponoy, Lavrentyevskiy, Pacha and Purnach), some small nepheline syenite massifs (Sakharjok, Kulijok) and numerous late- and postmagmatic bodies (intragranite pegmatite, peralkaline granite pegmatite, amazonite pegmatite, metasomatically altered rocks, etc.). The late- and postmagmatic bodies are different in size, composition, location in exo- as well as endocontact zones of parent granite massifs but often contain rare metal mineralization.

The Sakharjok is a pint-sized massif $(1.5-2 \times 8 \mathrm{~km})$ located within peralkaline granites of the Keivy block (Figure 1). The main rocks are alkaline syenites, nepheline syenites and genetically related pegmatoid schlierens and veins. The geology and petrology of the Sakharjok massif are described in detail in [26,27]. Large essexite (alkaline gabbro) body outcrops in an area up to $80 \times$ $200 \mathrm{~m}$ within nepheline syenite. Essexite is made up by phlogopite-pyroxene-plagioclase rock with minor nepheline and amphibole. Syenite intrudes essexite resulting in the formation of numerous fractures subsequently filled by a pegmatitic material. Pegmatite has a complex internal structure and is enriched in beryllium. The surface of pegmatite body outcrop is approximately $30 \mathrm{~m}^{2}$. Contact aureole of metasomatically altered rocks contaning essential biotite up to $80-90 \%$ (biotite metasomatite) wraps around the pegmatite.

The El'ozero rare-metal occurrence is confined to a linear tectonic zone along the contact of amphibolitized gabbro-anorthosite with the peralkaline granite of the Keivy block (Figure 1). The granite intruded and metasomatically altered the host rocks. As a result different rock types, including mineralized granites, peralkaline granite veins, pegmatites, granite-aplite and locally quartz 
veins and various metasomatically altered rocks were formed at the contact zone. The numerous $\mathrm{Zr}-\mathrm{Y}$-REE-Nb ore occurrences and deposits are associated with these rocks [22,28].

The Kanozero peralkaline granite massif is situated in the south of Kola Peninsula within the Belomorian block (Figure 1). The main rocks are peralkaline granite, granite-aplite and alaskite [29]. Numerous amazonite pegmatites occur in exo- and endocontact zones respect to the parental granites of the Kanozero massif. The exocontact zone of the massif is made up by a breccia, in which pegmatitic materials with peralkaline granite and granite-aplite filled the space between the fragments of the basic country rocks. These pegmatite bodies most probably have formed by metasomatic reworking and recrystallization of aplite. In the endocontact zone, pegmatitic bodies filled the cracks in parental granite. In some of pegmatitic bodies pink or greenish microcline forms instead of amazonite. This indicates a higher temperature of pegmatitic process.

The Khibiny alkaline massif is located in the center of the Kola Peninsula, at the contact of the Imandra-Varzuga Proterozoic greenstone belt with the Archaean metamorphic complexes of the Kola-Norwegian megablock (Figures 1 and 2). In plan view, the massif is elliptical $(45 \times 35 \mathrm{~km}$ ) with concentrically-zoned structure; in vertical section it is cone-like, with its apex pointing downward. The massif consists dominantly of foyaite/khibinite (a nepheline syenite with predominant K-feldspar; about $70 \%$ of the outcrop area) and foidolite ( $8 \%$ of the outcrop area) that intruded into the foyaite massif along the Main Ring fault [30]. Highly potassic poikilitic nepheline syenites, "rischorrites" (10\% of the outcrop area), commonly occur between the rocks of the Main Ring and the foyaite. The foidolite of the Main Ring accommodates all the apatite deposits and occurrences. Khibiny is somewhat a Mecca for mineralogists and mineral collectors due to numerous pegmatites and hydrothermal veins comprising unique assemblages of rare minerals. Their mineral composition strongly depends on the type of host rock [31]. Processes of local albitization, micatization and astrophyllitization are usually also imposed on the veins, leading to their transformation to albitites and other metasomatically altered rocks, practically indistinguishable from surrounding altered syenite rocks. Rather peculiar veins of quartz-syenite, syenite and nepheline-syenite with high concentrations of corundum, hercynite, topaz, almandine, pyrrhotite, pyrite and scarce accessories such as chrysoberyl, gadolinite-(Ce), chevkinite-(Ce), buergerite, native iron, sulfur, crichtonite, alabandite, and akaganeite are associated with xenoliths of hornfels. Ultimately, there are two different geological settings: veins in alkaline rocks and veins in xenoliths of hornfels.

The Lovozero alkaline massif intruded Archean granite-gneiss and Devonian tuff-basalt strata of the Kola-Norwegian megablock (Figures 1 and 2). It comprises regularly alternating subhorizontal layers of foyaite-malignite (a nepheline syenite containing 50 vol \% aegirine; "lujavrite") and ijolite-urtite. The alkaline rock strata are divided into two complexes-Differentiated (bottom) and Eudyalite (top) that differ in eudyalite content, nepheline-syenite-foidolite proportion and thickness of individual layers. The near-contact zone of fenitized rocks extends for 50-200 m. Fenites are represented by eudialite-microcline and amphibole-oligoclase varieties. Numerous nepheline syenite veins and alkaline pegmatites penetrated the country rocks at the distance of more than $100 \mathrm{~m}$ from the contact. Like at the Khibiny, pegmatites and hydrothermal veins are widespread within the massif [32]. They are very diverse in size, geological environment, composition and genesis. There are pegmatites also in xenoliths of country rocks.

Kovdor is an alkaline ultrabasic carbonatite-bearing pluton within Belomorian block (Figure 1) [33-35]. The outer contacts are subvertical or dip steeply to the centre of the massif. The contacts between different rock types inside the massif are also subvertical, thus the Kovdor massif can be represented as a neck. The Kovdor massif has concentric zonation, with axial peridotite; marginal melilitolite and intermediate diopsidite, phlogopitite and skarn-like rocks. Final stages of the massif formation include a pipe of phoscorite and carbonatite in western part of the melilitolite-foidolite ring as well as numerous dykes of carbonatites, nepheline syenites, and foidolites. 


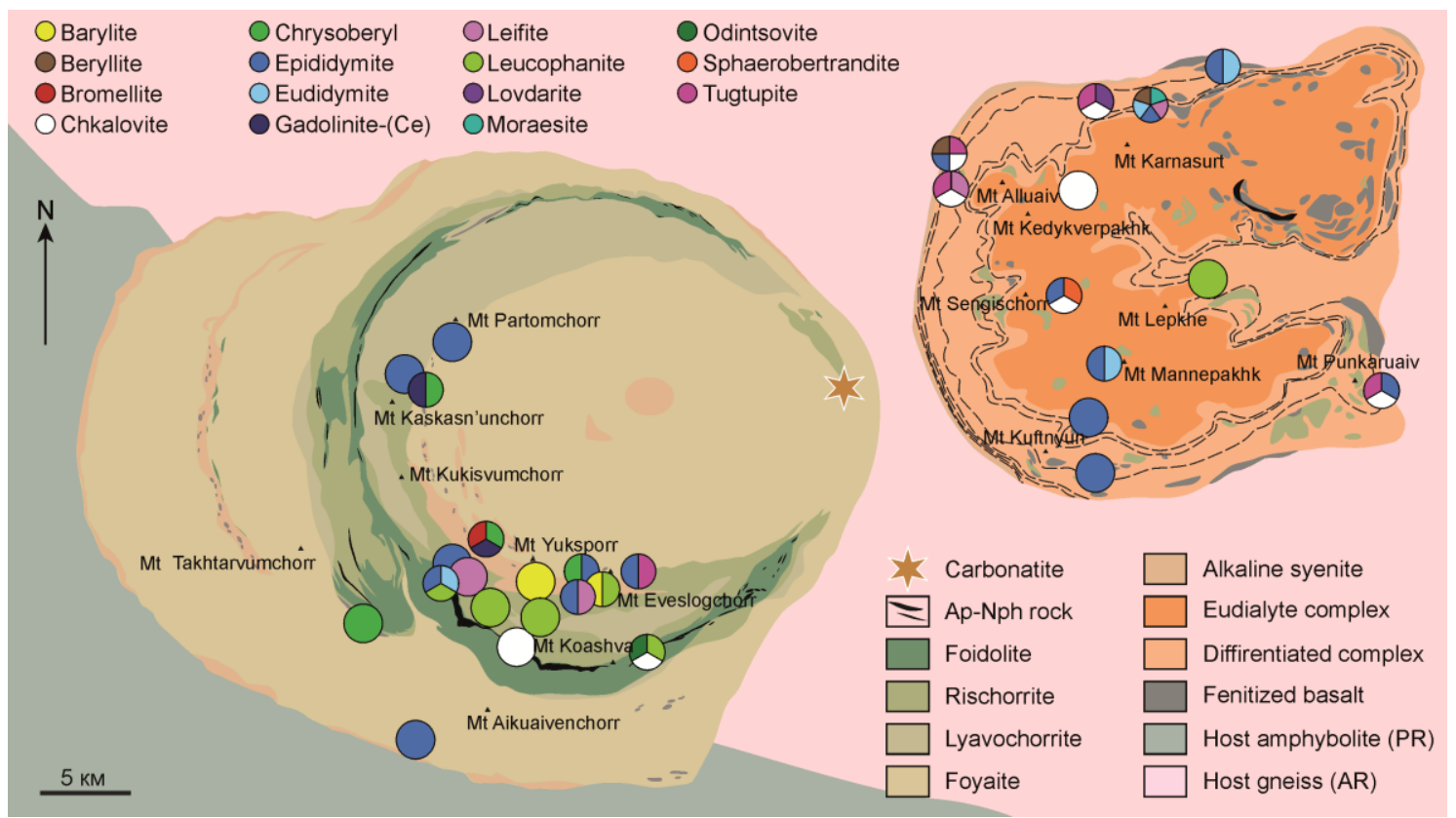

Figure 2. Simplified geological map of the Khibiny-Lovozero alkaline complex (after [22]), with localities of Be minerals.

The Jona occurrence is represented by Proterozoic granite pegmatite bodies within metamorphic rocks-gneisses, migmatites and amphibolites (Figure 1). The lenticular pegmatite bodies extend up to $500 \mathrm{~m}$ in depth. These pegmatites are a source of mica and ceramic raw materials [36].

The Strel'na occurrence is represented by Strel'na pegmatite field in South-East of Kola Peninsula (Figure 1). Plagioclase-microcline pegmatites are hosted by muscovite gneisses [37].

\section{The Source Data for the Review}

The most of the reports and papers on beryllium minerals of the Kola Peninsula were published in the 1950-70s and only in Russian, and therefore are not accessible to a wide audience. That is why, in this review the authors tried to collect all the data in brief form from previous Russian publications. The new original data are also provided. In this paper, beryllium minerals of the Kola Peninsula are described. The authors want to emphasize the following points. (1) Geological settings, the rocks and names of minerals are presented according to the author's text if it is not possible to clarify them. For example, "apatite" or "garnet" means members of these groups without an proper determination of their chemical composition. (2) The authors provide a synthesis of all the available information on mineral paragenesis. According to the source data we present the "mineral paragenesis" as a common occurrence of minerals which formed at the same time, or in a sequence, during a single mineralization process.

The following designations are used in the tables of mineral composition: EMP-electron microprobe and WCA-wet chemistry analyses, correspondingly; calc-beryllium content was calculated, wet-beryllium content was determined by wet chemistry method. The photos of minerals are selected to show the most typical morphologies and mineral associations.

Sometimes the distinctive features of minerals comparing to type localities are presented. The last ones include variations in composition, unusual morphology, special physical properties and other characteristics. A special attention is paid to the rate of study of individual minerals-for some of them only the presence in the occurrence is indicated, while others have been repeatedly studied. As a result, the description of minerals varies greatly in volume and completeness of information. 


\section{Beryllium Minerals from the Kola Peninsula}

Kola Peninsula is not remarkable for significant resources of beryllium. On a whole the north-western part of Russia possesses $13.9 \%$ of all-Russian beryllium reserves (http:/ / vims-geo.ru). Nevertheless, the Kola Peninsula demonstrates the unique diversity of beryllium minerals.

The first Be mineral discovered on the Kola Peninsula was apparently leucophanite from the Khibiny massif and mentioned by Chernik [38] and Kostyleva [39,40]. In total 28 beryllium minerals are established on the Kola Peninsula up today (Table 1). According with the classification of Pekov [5], among them only beryl is widespread, others are less common (as chrysoberyl and bertrandite) and most occur as trace minerals.

Table 1. List of beryllium minerals on Kola Peninsula.

\begin{tabular}{|c|c|c|}
\hline $\begin{array}{l}\text { Location/ } \\
\text { Geological Era }\end{array}$ & Geological Setting & $\begin{array}{l}\text { Minerals of Beryllium in Location and } \\
\text { Geological Setting According Column } 2\end{array}$ \\
\hline $\begin{array}{l}\text { Kolmozero-Voronja } \\
\text { belt/AR }\end{array}$ & spodumene pegmatite & $\begin{array}{l}\text { Silicates } \\
\text { bavenite, bertrandite, beryl }{ }^{*} \text {, milarite }\end{array}$ \\
\hline Shongui/AR? & granite pegmatite & $\begin{array}{l}\text { Silicates } \\
\text { beryl }\end{array}$ \\
\hline $\begin{array}{l}\text { Keivy alkaline } \\
\text { province/AR }\end{array}$ & $\begin{array}{l}\text { 1. pegmatite of peralkaline granite } \\
\text { 2. quartz-epidote metasomatites } \\
\text { 3. amazonite pegmatite } \\
\text { 4. veins of peralkaline granite } \\
\text { 5. intragranite pegmatite of } \\
\text { peralkaline granite } \\
\text { 6. nepheline syenite pegmatite } \\
\text { 7. biotite metasomatite }\end{array}$ & $\begin{array}{l}\text { Silicates } \\
\text { danalite }(2) \text {, gadolinite-(Ce) }(2) \text {, gadolinite- }(\mathbf{Y}) \\
(1,3,4,5) \text {, genthelvite }(1) \text {, hingganite- }(\mathrm{Ce})(2), \\
\text { hingganite-( }(\mathrm{Y})(3,5), \text { hingganite- }(\mathrm{Yb})(3), \\
\text { leucophanite }(7), \text { meliphanite }(6,7) \\
\text { Oxides and Hydroxides } \\
\text { behoite }(6)\end{array}$ \\
\hline Kanozero/PR & amazonite pegmatite & $\begin{array}{l}\text { Silicates } \\
\text { gadolinite-(Y) }\end{array}$ \\
\hline Strel'na/PR & granite pegmatite & $\begin{array}{l}\text { Silicates } \\
\text { beryl, bertrandite }\end{array}$ \\
\hline Jona/PR? & granite pegmatite & $\begin{array}{l}\text { Silicates } \\
\text { beryl }\end{array}$ \\
\hline Khibiny massif/PZ & $\begin{array}{l}\text { 1. pegmatite and hydrothermal } \\
\text { veins within alkaline rocks } \\
\text { 2. veins in xenolithes of hornfels } \\
\text { 3. alkaline syenite }\end{array}$ & $\begin{array}{l}\text { Silicates } \\
\text { barylite (1), beryllite (1), chkalovite (1), } \\
\text { epididymite (1), eudidymite (3), gadolinite-(Ce) } \\
(2) \text {, leifite (1), leucophanite (1), odintsovite (1), } \\
\text { sphaerobertrandite (1), tugtupite (1) } \\
\text { Oxides and Hydroxides } \\
\text { bromellite (2), chrysoberyl (2) }\end{array}$ \\
\hline Lovozero massif/PZ & $\begin{array}{l}\text { 1. pegmatite and hydrothermal } \\
\text { veins within alkaline rocks } \\
\text { 2. quartz-albite rock } \\
\text { (without nepheline) } \\
\text { 3. albitite } \\
\text { 4. contact fenite } \\
\text { 5. feldspar pegmatite in xenolithes }\end{array}$ & $\begin{array}{l}\text { Silicates } \\
\text { barylite }(1) \text {, beryllite }(1) \text {, chkalovite }(1) \text {, eirikite } \\
\text { (1), epididymite }(1,2,4,5) \text {, eudidymite }(1,3), \\
\text { genthelvite }(5), \text { leifite }(1) \text {, leucophanite }(1) \text {, } \\
\text { lovdarite }(1) \text {, sphaerobertrandite }(1) \text {, tugtupite (1) } \\
\text { Phosphates } \\
\text { moraesite (1) }\end{array}$ \\
\hline Kovdor/PZ & fenite & $\begin{array}{l}\text { Silicates } \\
\text { epididymite }\end{array}$ \\
\hline
\end{tabular}

* Bold for minerals occurring in more than one location.

The agpaitic massifs Khibiny and Lovozero have the highest number of Be minerals-17 species up today (Figure 2). Other occurrences are from perakaline granites and syenites of the Keivy alkaline province (11), spodumene pegmatites of Kolmozero-Voronja belt (4), Kovdor alkaline-ultrabasic massif (1), peralkaline granites of Kanozero (1), and from granite pegmatites of Jona (1), Shongui (1), and Strel'na (2). The distribution of these minerals in the mineral classes is as follows: 24 mineral 
species for silicates, 3 for oxides and hydroxides, 1 for phosphate. The discoveries of new beryllium minerals are related mainly to Khibiny and Lovozero massifs, including chkalovite [41], beryllite [42], tugtupite (Tugtupite was discovered almost simultaneously at llímaussaq (named tugtupite) and Lovozero (named beryllosodalite); the former is considered the type locality) [43], and lovdarite [44]. Hingganite-( $(\mathrm{Yb})$ was firstly described from pegmatites related to Keivy peralkaline granite [45].

As was mentioned above, beryllium is accumulated in the late products of felsic and alkaline magmatic rocks. Thereby the abundant beryllium minerals occur almost in pegmatites, hydrothermal veins and metasomatically altered rocks. Similar occurrences are described for Kola Peninsula: the most rich and diverse Be mineralization is found in highly differentiated alkaline pegmatites. The age span for Kola alkaline rocks ranges from Late Archean to Paleozoic suggesting the high perspectivity of them for beryllium minerals.

Barylite $\mathbf{B a B e}_{2} \mathbf{S i}_{2} \mathbf{O}_{7}$ was found [46] and thoroughly studied [47] in pegmatites intruding in nepheline syenite of Mts Eveslogchorr, Rasvumchorr and Yuksporr, Khibiny massif (Figure 2). All these pegmatites are zonal, with microcline-dominant marginal zones and a natrolite core [20].

The most famous occurrence is in a barylite-bearing lens which is located within gneissose foyaite in Mt Yuksporr [20]. Barylite forms sheaf-like and radiated aggregates up to $3 \mathrm{~cm}$ in diameter, composed of lamellar crystals of pale-creamy color (Figure 3). Barylite aggregates occur in interstices amongst blocky feldspar, long prismatic aegirine and tabular catapleiite, associated with apatite group minerals, labuntsovite-Mn, astrophyllite, titanite and strontianite. In other cases, interstices in microcline aggregate are filled by radially-fibrous natrolite with sheaf-like splices of lamellar barylite crystals. Composition of Yuksporr barylite is given in Table 2. Barylite from Khibiny massif is of two rhombic polytypes: $\mathrm{MDO}_{1}$ polytype, space group $P m n 2_{1}$; and $\mathrm{MDO}_{2}$ polytype, space group $P m n b[20,48,49]$. Barylite from the Yuksporr pegmatite has a rhombic cell $P m n 2_{1}$ [50]. Now clinobarylite is discredited and is referred to $\mathrm{MDO}_{1}$ polytype of barylite.

Table 2. Chemical composition of barylite.

\begin{tabular}{cc}
\hline Sample $^{*}$ & 1, EMP \\
\hline Component & wt \% \\
\hline $\mathrm{SiO}_{2}$ & 36.74 \\
$\mathrm{CaO}$ & 0.03 \\
$\mathrm{BeO}$ & $15.50_{\text {wet }}$ \\
$\mathrm{BaO}$ & 47.02 \\
\hline Total & 99.29 \\
\hline * Sample: 1-Yuksporr, Khibiny [47].
\end{tabular}

Another occurrence of barylite is known from the natrolite core of a pegmatite at Mt Kuamdespahk, Lovozero massif [49]. The mineral composition and crystal structure are similar to the described in the Yuksporr occurrence. Barylite forms lamellar crystals and is associated with microcline, aegirine, natrolite, fluorapatite, titanite, catapleiite, labuntsovite, astrophyllite and strontianite.

There is a personal communication of Voloshin [49] about the barylite finding in the Vuorijarvi carbonatite. 


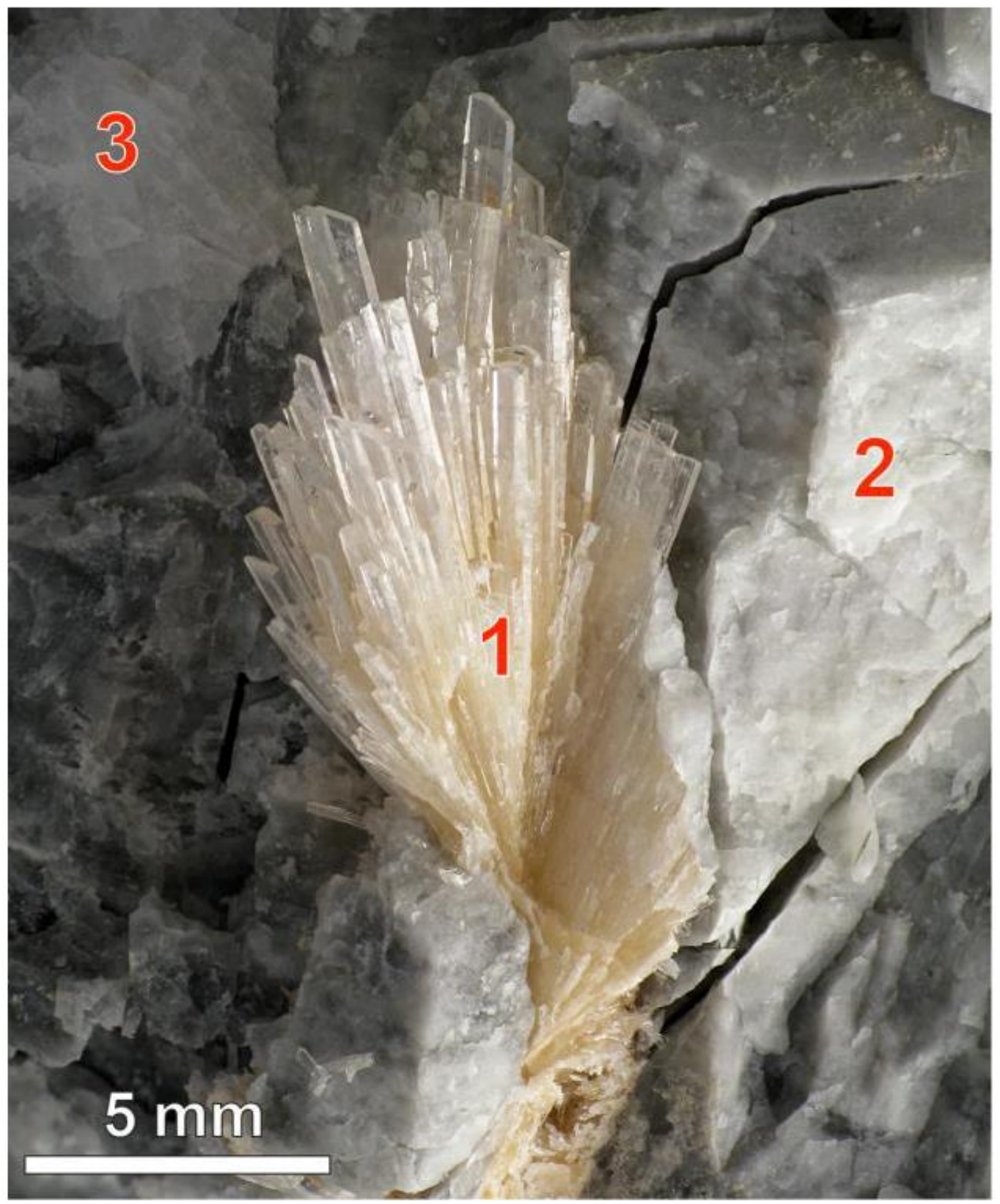

Figure 3. Sheaf-like aggregate of barylite (1) on microcline (2), with natrolite (3), from a microcline-natrolite vein in foyaite, Mt Yuksporr, Khibiny.

Bavenite $\mathrm{Ca}_{4} \mathrm{Be}_{2} \mathrm{Al}_{2} \mathrm{Si}_{9} \mathrm{O}_{26}(\mathrm{OH})_{2}$ was found in spodumene pegmatites of the Kolmozero-Voronja belt (Figure 1) and confirmed by X-ray study [51]. The mineral is rare and occurs in two associations: (a) in association with late suggary (granular) albite as radially-fibrous aggregates of $0.1-1 \mathrm{~cm}$ (Figure 4) or as tiny veins of $0.01-0.1 \mathrm{~mm}$ thick, and (b) in cavities produced by leaching of spodumene, where it is a late mineral, covering quartz, microcline, albite, and stilbite and mantled on its turn by later chabazite-(Ca) and calcite. 


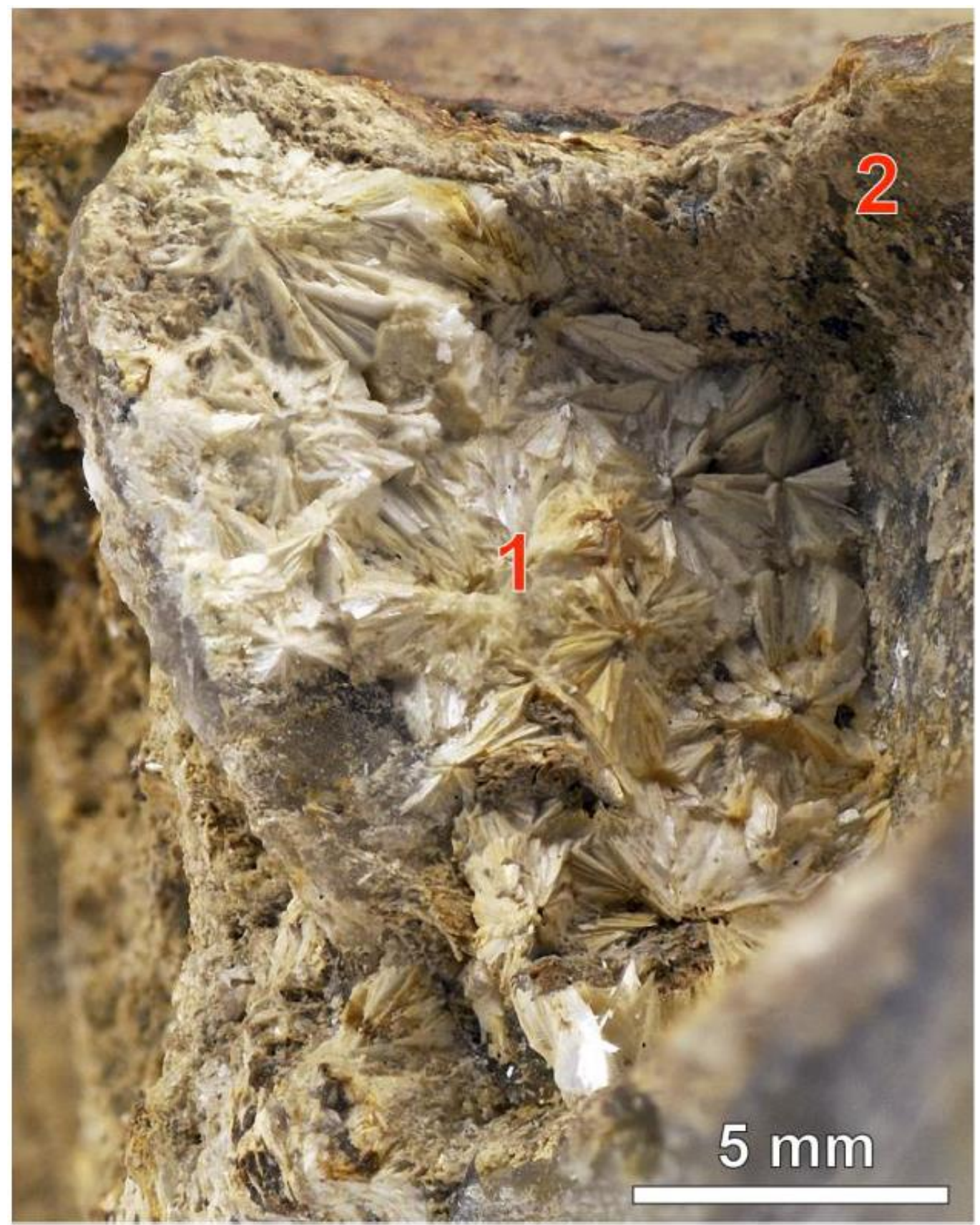

Figure 4. Radiated bavenite aggregates (1) in albite (2), from a spodumene pegmatite, Kolmozero-Voronja.

Comparing to type locality (Baveno, Italy) and other occurrences [51-53], bavenite from Kolmozero-Voronja pegmatites is characterized by moderately high $\mathrm{BeO}$ and $\mathrm{Na}_{2} \mathrm{O}$ and very low $\mathrm{CaO}$ (Table 3). The relations of elements in this mineral are determined by the following scheme ${ }^{\mathrm{T}(3)} \mathrm{Be}+$ $\mathrm{O}(\mathrm{OH})+\mathrm{Na}+2^{\mathrm{T}(4)} \mathrm{Si} \rightarrow{ }^{\mathrm{T}(3)} \mathrm{Si}+2 \mathrm{O}+\mathrm{Ca}+2^{\mathrm{T}(4)} \mathrm{Al}[52]$. 
Table 3. Chemical composition of bavenite.

\begin{tabular}{cccc}
\hline Sample $^{*}$ & 1, WCA & 2, EMP & 3, WCA \\
\hline Component & \multicolumn{3}{c}{ wt \% } \\
\hline $\mathrm{SiO}_{2}$ & 58.88 & 61.48 & 56.93 \\
$\mathrm{Al}_{2} \mathrm{O}_{3}$ & 7.83 & 3.54 & 12.38 \\
$\mathrm{Fe}_{2} \mathrm{O}_{3}$ & 0.46 & - & - \\
$\mathrm{CaO}$ & 15.74 & 23.44 & 24.47 \\
$\mathrm{BeO}$ & 10.3 & 8.96 & 2.67 \\
$\mathrm{MgO}$ & 0.20 & - & 0.12 \\
$\mathrm{Na}_{2} \mathrm{O}$ & 1.46 & 0.30 & 0.29 \\
$\mathrm{H}_{2} \mathrm{O}^{+}$ & 4.92 & 3.48 & 2.49 \\
\hline Total & 99.79 & 101.20 & 99.72 \\
\hline * Samples: 1-Kolmozero-Voronja [51]; 2,3-Baveno, Italy [52,53].
\end{tabular}

Behoite $\mathrm{Be}(\mathrm{OH})_{2}$ is described from nepheline syenite pegmatite in Sakharjok massif (Figure 1), Keivy alkaline province [54]. Behoite occurs in leaching cavities up to $1.5-2 \mathrm{~mm}$ in size between euhedral aegirine-augite crystals (Figure 5). The mineral forms brown powder-like aggregates and closely associates with prehnite. Identification of behoite is based on coincidence of its X-ray powder diffraction pattern with that of behoite from Texas [55] and absence of characteristic lines of any elements in EDS spectrum. Behoite is a product of hydrothermal alteration of meliphanite.

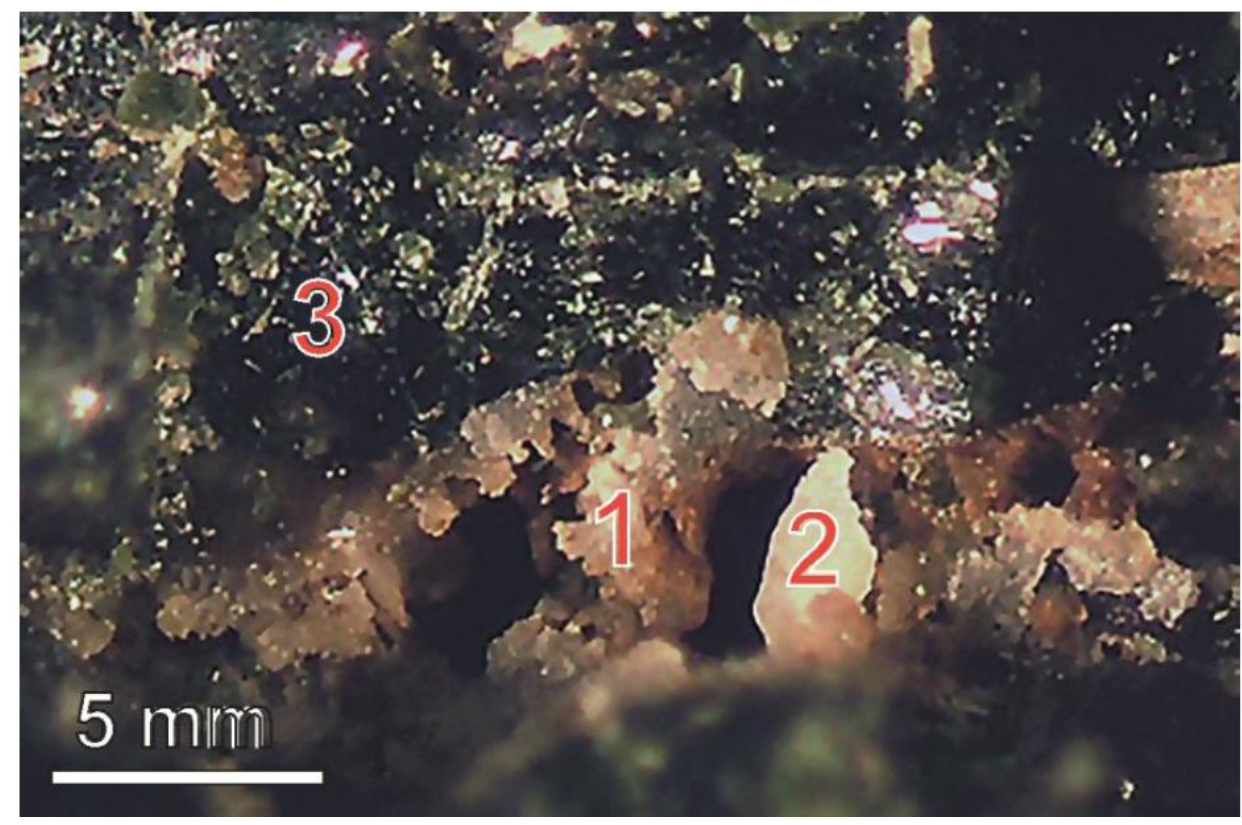

Figure 5. Powder-like aggregate of behoite (1) with prehnite (2) in leaching cavities of aegirine-augite (3) in nepheline-syenite pegmatite, Sakharjok.

Bertrandite $\mathrm{Be}_{4} \mathrm{Si}_{2} \mathrm{O}_{7}(\mathrm{OH})_{2}$ is an extremely rare mineral in Kola Peninsula, despite the wide range of conditions suitable for its formation. It was found [51] in clayish aggregate from a cavity in beryl crystal in spodumene pegmatite, Kolmozero-Vornja belt (Figure 1). The mineral forms very thin plates up to $0.2 \mathrm{~mm}$ in size. Bertrandite is apparently a secondary mineral. Its mineral identification is confirmed by X-ray study, but compositional data are not available.

The bertrandite formed along with the clay minerals at the expense of beryl in pegmatites of the Strel'na field [37]. It is characterized by tabular or elongated flattened crystals set amidst the mica unit. Only qualitative spectral analysis of this mineral is given. 
The finds of bertrandite are mentioned in some publications on the Lovozero massif [32,56], but most likely the authors mean sphaerobertrandite [57] which was considered a variety of bertrandite.

Beryl $\mathrm{Be}_{3} \mathrm{Al}_{2} \mathrm{Si}_{6} \mathrm{O}_{18}$ is a common mineral in quartz-albite-microcline pegmatite bodies from Kolmozero-Voronja, Jona, Strel'na, Shongui and Olenegorsk occurrences (Figure 1). Beryl is one of the exploited minerals in Kolmozerskoe deposit.

Beryl from the Kolmozero-Voronja belt was formed during several stages [51]. The earliest beryl (I) occurs as long-prismatic crystals (up to $20 \mathrm{~cm}$ long and $5 \mathrm{~cm}$ in diameter) amongst coarse-grained quartz-albite-microcline aggregates of the albite-microcline pegmatite (Figure 6a).

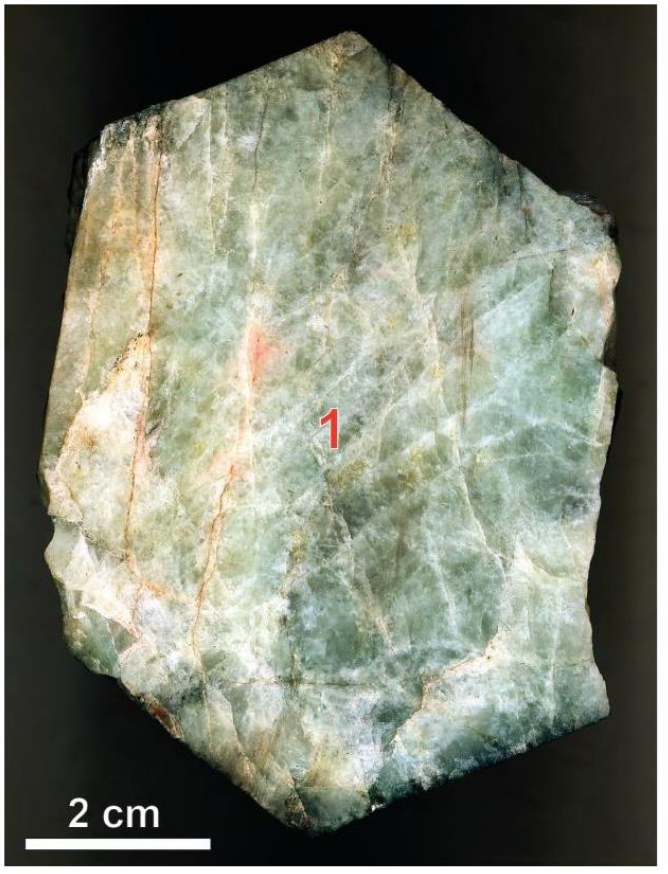

(a)

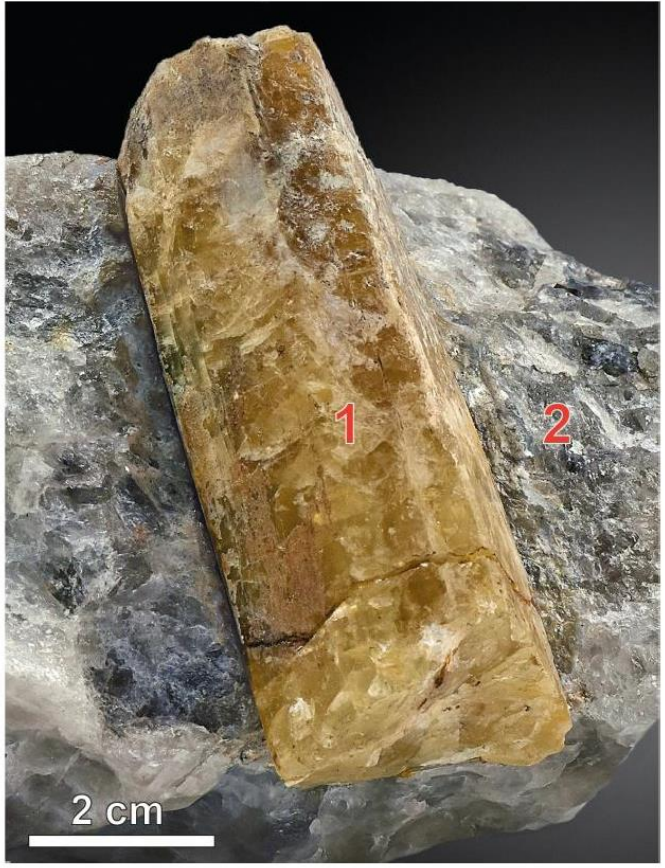

(b)

Figure 6. Beryl (1): (a) section of long-prismatic beryl crystal from granite pegmatite of the Olenegorsk deposit; (b) crystal with quartz (2) from quartz-albite-microcline pegmatite, Kolmozero-Voronja.

The second stage beryl (II) occurs as euhedral short-prismatic crystals (up to $5 \mathrm{~cm}$ long) within medium-grained quartz-albite-spodumene aggregates (zone 3). The mineral includes the grains of quartz, spodumene and albite and is cut by muscovite laths.

The third stage beryl (III) occurs within the coarse-grained quartz-spodumene blocks (zone 4), where equidimensional mineral grains reach $0.5 \mathrm{~m}$. It crystallizes after spodumene and microcline but before albite and muscovite. Beryl from quartz-muscovite lenses (zone 5) also belongs to the third stage. Here mineral forms coarse agglomerations.

The latest beryl (IV) was formed during recrystallization of the earlier beryl and its replacement by suggary albite. This mineral occurs as euhedral crystals of $0.2-10 \mathrm{~mm}$ size. During spodumene leaching and zeolite formation beryl decomposes to bertrandite and bavenite.

In ceramic pegmatites cutting rocks of the Olenegorsk Banded Iron-Formation, there are well shaped long-prismatic beryl crystals up to $50 \mathrm{~cm}$ long and $10 \mathrm{~cm}$ in diameter (Figure 6b) associated with phlogopite, muscovite, members of the dravite-shorl tourmaline series, spessartine, fluorapatite, ilmenite and ferrocolumbite.

Several dozens of beryl chemical analyses are available [51,58]. From the content of major constituents $\left(\mathrm{BeO}, \mathrm{Al}_{2} \mathrm{O}_{3}, \mathrm{SiO}_{2}\right)$ beryl from Kolmozero-Voronja pegmatites are fully consistent to stoichometric formula (Table 4). BeO varies from 11.36 to $13.90 \mathrm{wt} \%$, whereas zone 3 beryl contains an average $\mathrm{BeO} 12.25 \mathrm{wt} \%$, zone 4 beryl-11.9 wt \%, zone 5 beryl-12.6 wt \%. The latest fine-grained 
beryl from albitization zones contains the lowest BeO-11.3 wt \%. Beryl from Kolmozero-Voronja is characterized by elevated contents of alkaline elements: $\mathrm{Li}_{2} \mathrm{O}$ ranges from 0.3 to 1 wt $\%, \mathrm{Na}_{2} \mathrm{O}$ $1.1-2.3 \mathrm{wt} \%, \mathrm{Rb}_{2} \mathrm{O} 0.01-0.06 \mathrm{wt} \%, \mathrm{Cs}_{2} \mathrm{O} 0.12-0.87 \mathrm{wt} \%$. At a whole, the total content of alkalis in beryl increases from marginal to central part of pegmatites. Sosedko [59] mentions the $7.23 \mathrm{wt} \%$ of total alkalis (from which $\mathrm{Cs}_{2} \mathrm{O}$ content is $4.13 \mathrm{wt} \%$ ) in beryl from central zone 4 . Beryl decomposition led to crystallization of other Be minerals, as bertrandite and bavenite.

Table 4. Chemical composition of beryl.

\begin{tabular}{cccccc}
\hline Sample * & 1, WCA & 2, WCA & 3, WCA & 4, WCA & 5, EPM \\
\hline Component & \multicolumn{5}{c}{ wt \% } \\
\hline $\mathrm{SiO}_{2}$ & 64.84 & 63.30 & 63.78 & 64.90 & 67.00 \\
$\mathrm{TiO}_{2}$ & 0.04 & - & - & 0.02 & - \\
$\mathrm{Al}_{2} \mathrm{O}_{3}$ & 16.10 & 17.97 & 18.23 & 17.49 & 18.63 \\
$\mathrm{Fe}_{2} \mathrm{O}_{3}$ & 1.00 & 0.21 & 0.28 & - & 0.44 \\
$\mathrm{FeO}$ & - & 0.26 & 0.13 & 0.72 & - \\
$\mathrm{MnO}$ & - & - & 0.12 & - & - \\
$\mathrm{BeO}$ & 12.90 & 12.37 & 11.60 & 12.72 & $13.66_{\text {calc }}$ \\
$\mathrm{MgO}$ & 0.78 & 0.02 & 0.15 & 0.23 & - \\
$\mathrm{CaO}$ & 0.19 & 0.25 & 0.42 & 0.12 & - \\
$\mathrm{Na} 2 \mathrm{O}$ & 1.00 & 1.67 & 1.71 & 1.20 & 0.27 \\
$\mathrm{~K}_{2} \mathrm{O}$ & 0.55 & - & - & - & - \\
$\mathrm{Li}_{2} \mathrm{O}$ & 0.04 & 0.74 & 0.74 & 0.41 & - \\
$\mathrm{Cs}_{2} \mathrm{O}$ & - & 0.20 & - & - & - \\
$\mathrm{Rb}_{2} \mathrm{O}$ & - & 0.04 & - & - & - \\
$\mathrm{H}_{2} \mathrm{O}$ & 2.45 & 2.75 & 2.63 & 2.52 & - \\
\hline $\mathrm{Total}^{+}$ & 100.07 & 100.18 & 99.83 & 100.33 & 100.00
\end{tabular}

* Sample: 1-1 stage, 2—2 stage, 3-3 stage, Kolmozero-Voronja [51]; 4-Strel'na [37]; 5-Olenegorsk (analyst Ya.A. Pakhomovsky, KSC RAS).

Beryl is found as an accessory mineral in undifferentiated plagioclase-microcline pegmatites occurring among the mica gneisses in pegmatites of Strel'na field [37]. Beryl is related to the plagioclase areas. Beryl is represented by well-faceted prismatic crystals up to $15 \mathrm{~cm}$ in length. Those crystals are often opaque, covered by a dense network of cracks intersecting in different directions.

Samples of beryl collected from granite pegmatites of Jona and Shongui are stored in the Museum of GI KSC RAS.

Beryllite $\mathrm{Be}_{3} \mathrm{SiO}_{4}(\mathrm{OH})_{2} \cdot \mathrm{H}_{2} \mathrm{O}$ was firstly described from the concentrically zoned natrolitized alkaline pegmatite Natrolite Stock, hosted by sodalite-nepheline syenite of Mt Karnasurt in the Lovozero massif (Figure 2) [42]. The mineral overgrowths epididymite forming white to brown spherulites up to 2-3 $\mathrm{mm}$ and waxy crusts of these spherulites (up to $2 \mathrm{~mm}$ thick) in leaching cavities of chkalovite (Figure 7). Beryllite is associated with fine-grained albite and epididymite which it overgrows. Composition of beryllite is given in Table 5. Another beryllite locality is large (above $2 \mathrm{~m}$ in diameter) ussingite pegmatite in foidolite-lujavrite of Mt Alluaiv (Figure 2), where similar berrylite crystals (up to $1 \mathrm{~mm}$ thick) together with epididymite, hydroxycancrinite, and $\mathrm{K}$-Ca zeolites incrust intersices in the marginal aegirine-microcline zone. 


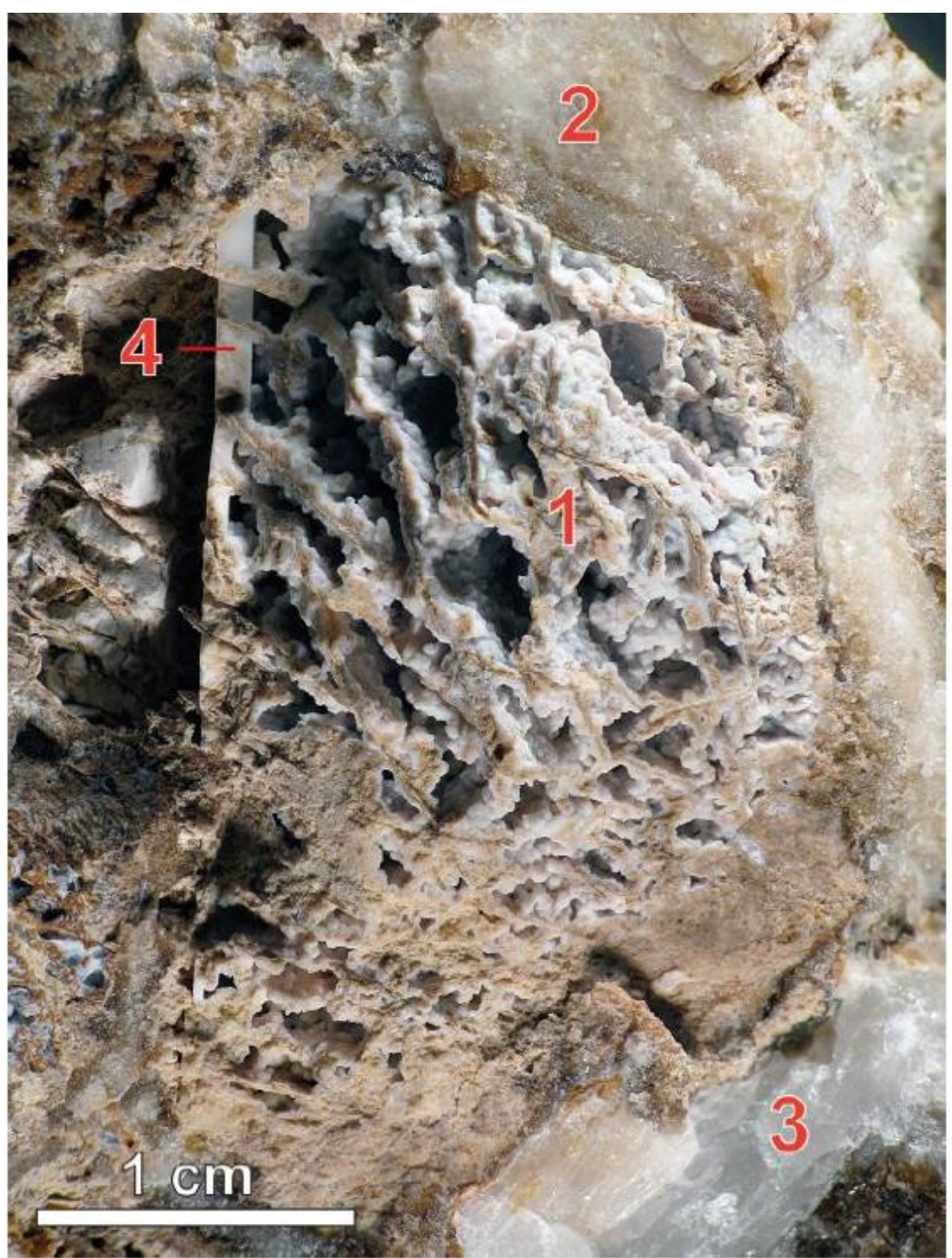

Figure 7. Beryllite (1) pseudomorph after chkalovite, in albite (2), from an aegirine-feldspar lens in sodalite-nepheline syenite, Mt Karnasurt, Lovozero. (3)-Natrolite, (4)-microcline.

Table 5. Chemical composition of beryllite.

\begin{tabular}{cc}
\hline Sample $^{*}$ & 1, WCA \\
\hline Component & wt \% \\
\hline $\mathrm{SiO}_{2}$ & 34.10 \\
$\mathrm{Al}_{2} \mathrm{O}_{3}$ & 1.63 \\
$\mathrm{Fe}_{2} \mathrm{O}_{3}$ & 0.12 \\
$\mathrm{BeO}$ & 40.00 \\
$\mathrm{CaO}$ & 0.50 \\
$\mathrm{Na}_{2} \mathrm{O}$ & 2.42 \\
$\mathrm{H}_{2} \mathrm{O}^{+}$ & 18.95 \\
\hline Total & 97.22 \\
\hline
\end{tabular}

* Sample: 1-Lovozero [42]. 
Other beryllite findings in the Kola Peninsula are unreliable. The mineral is mentioned from Mt Mannepahk in the Lovozero massif [60], as fibrous aggregates overgrowing chkalovite from Mt Punkuruaiv in the Lovozero massif and from natrolite vein in Mt Kuelpor, Khibiny massif [61].

Kola Peninsula is the type locality for beryllite. Crystal structure of mineral has not yet been solved.

Bromellite $\mathrm{BeO}$ was found in a sodalite-nepheline-orthoclase vein, along with corundum, siderophyllite, ilmenite and fluorapatite, cutting hornfels xenoliths at Mt Kukisvumchorr, Khibiny massif [20,46]. Bromellite forms colorless hemimorphic crystals up to $3 \mathrm{~mm}$ as well as irregularly-shaped grains between the grains of nepheline and potassium feldspar. The mineral identification has been confirmed by powder X-ray study.

Chkalovite $\mathrm{Na}_{2} \mathbf{B e S i}_{2} \mathrm{O}_{6}$ is the first beryllium mineral discovered on the Kola Peninsula. It was found by Gerasimovsky [41] in natrolitized ussingite pegmatites hosted by eudialyte-rich foyaite of Mt Malyi Punkuruaiv, Lovozero massif (Figure 2, Table 6). The mineral forms large isometric crystals, up to $10 \mathrm{~cm}$, white to semitransparent and partially replaced by snow-white epididymite and crimson tugtupite. Characteristic associated minerals are sodalite, analcime, murmanite, epistolite, manganoeudyalite, manganoneptunite, tainiolite, manganonordite-(Ce)-ferronordite-(Ce), steenstrupine-(Ce), belovite-(Ce), rhabdophane-(Ce), sphalerite and galena. The crystal structure of chkalovite has been solved later $[62,63]$.

Table 6. Chemical composition of chkalovite.

\begin{tabular}{cccc}
\hline Sample * & 1, WCA & 2, WCA & 3, EMP \\
\hline Component & \multicolumn{3}{c}{ wt \% } \\
\hline $\mathrm{SiO}_{2}$ & 56.81 & 57.08 & 56.74 \\
$\mathrm{Fe}_{2} \mathrm{O}_{3}$ & 0.30 & - & - \\
$\mathrm{FeO}$ & 0.12 & - & - \\
$\mathrm{CaO}$ & 0.37 & - & - \\
$\mathrm{BeO}$ & 12.67 & 12.78 & 13.44 \\
$\mathrm{Na}_{2} \mathrm{O}$ & 28.93 & 29.49 & 29.07 \\
$\mathrm{~K}_{2} \mathrm{O}$ & 0.13 & - & - \\
$\mathrm{H}_{2} \mathrm{O}^{+}$ & 0.23 & 0.38 & - \\
$\mathrm{SO}_{3}$ & 0.22 & - & - \\
\hline $\mathrm{Total}^{2}$ & 99.78 & 99.73 & 99.25 \\
\hline * Sample: $1-\mathrm{M}$. Punkuruaiv, Lovozero [41], 2-Sengischorr, Lovozero [61], 3-Koashva, Khibiny [47].
\end{tabular}

The following numerous findings of chkalovite indicate that this mineral is typical of ultra-agpaitic ussingite pegmatites of the Lovozero massif: Mts Sengischorr, Punkuruaiv, Karnasurt, Lepkhe-Nelm, Kedykverpahk, Alluaiv [32,64-66]. Chkalovite is the earliest high temperature beryllium mineral from the pegmatites and it is a precursor for most Be mineral phases: tugtupite, beryllite, epididymite, lovdarite and sphaerobertrandite [32]. For example, the ussingite pegmatite "Palitra" in rocks of the Lovozero Differentiated complex at Mt Kedykvyrpakh contains transparent tabular chkalovite crystals (up to $5 \mathrm{~cm}$ in diameter) included in dark violet ussingite together with sodalite, natrolite, villiaumite, natrosilite, manaksite (Figure 8a), serandite, kapustinite, lomonosovite, vuonnemite, manganoneptunite, and other rare minerals [64]. In natrolitized protoussingite pegmatite "Yubileinaya", there are large (up to $15 \mathrm{~cm}$ in diameter) colorless chkalovite crystals partially or completely replaced by lovdarite and tugtupite, and associated with analcime, lorenzenite, lomonosovite, eudialyte, (mangano)nordite-(Ce), manganoneptunite, umbozerite, steenstrupine-(Ce) and products of their alteration (bornemanite, terskite, vitusite-(Ce), narsarsukite, zorite, raite, etc.) [32]. 


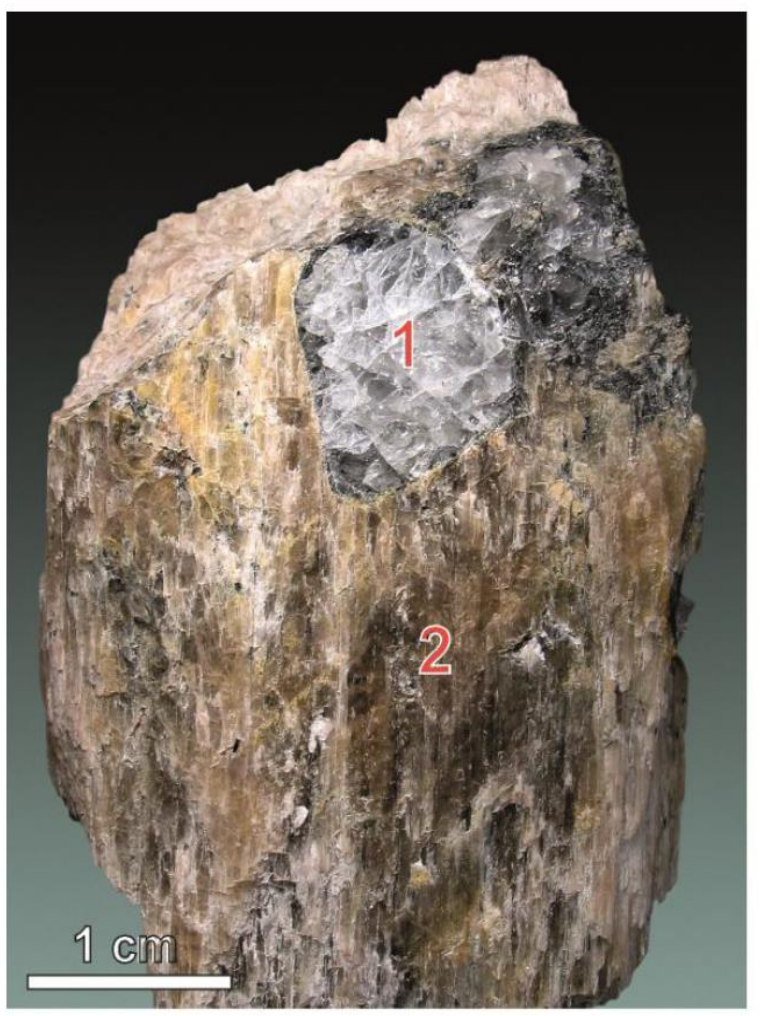

(a)

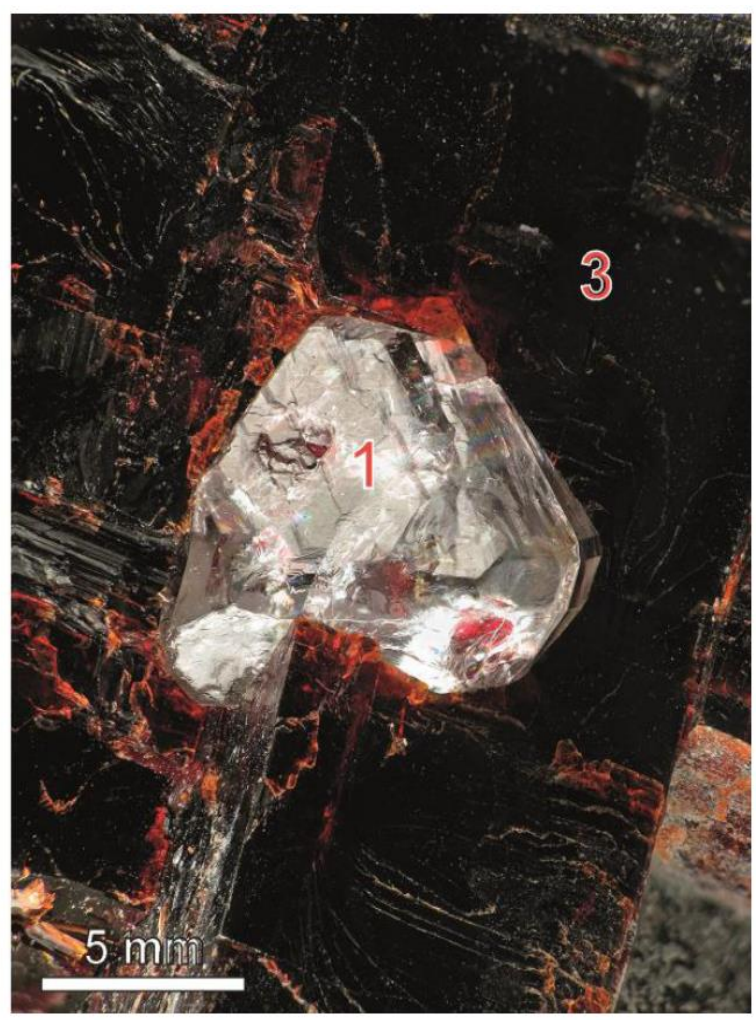

(b)

Figure 8. Chkalovite crystals (1): (a) in manaksite (2), from the "Palitra" pegmatite, Mt Kedykvyrpakhk, Lovozero; (b) in villiaumite (3), from a sodalite-microcline-aegirine vein in urtite, Mt Koashva, Khibiny.

In the Khibiny massif (Figure 2) chkalovite was firstly found in $20-40 \mathrm{~cm}$ thick microclinenepheline-sodalite-katophorite veins, hosted by urtite in Mt Rasvumchorr [67]. Pectolite-villiaumitechkalovite or monomineralic chkalovite aggregates fill the cracks in the veins; in many cases, these minerals fill out the veins completely.

The mineral was found also in a large sodalite-microcline-aegirine pegmatite in apatite-bearing urtite of Mt Koashva, Khibiny massif [20,47]. Chkalovite forms anhedral grains up to $4 \times 5 \mathrm{~cm}$ and rarely aggregates of euhedral $0.5-3 \mathrm{~cm}$ crystals. The mineral sets amongst microcline crystals and natrolite-pectolite aggregates and is associated with lomonosovite and lamprophyllite. Vitusite-(Ce) and nacaphite crystallize in leaching cavities in chkalovite. Other remarkable occurrence of chkalovite is the microcline-pectolite-sodalite-aegirine ultraagpaitic vein of Mt Koashva, Khibiny massif [20], where large (up to $10 \mathrm{~cm}$ ) euhedral colorless chkalovite crystals are included in dark-red villiaumite (Figure $8 \mathrm{~b}$ ) in close association with natrophosphate, lomonosovite, shcherbakovite, nefedovite, fluorcaphite, vitusite-(Ce), chlorbartonite, djerfisherite and cobaltite.

Chrysoberyl $\mathrm{BeAl}_{2} \mathrm{O}_{4}$ was found in drill core near Maly Vud'iavr Lake, Khibiny massif (Figure 2). The host rocks are fenitized basalt and tuff (so-called "hornfels") found as xenoliths in foyaite situated near the Main foidolite ring [68]. The mineral forms thick tabular crystals (up to $5 \mathrm{~mm}$ in diameter), twins and penetration trillings of pseudohexagonal habit. Composition of chrysoberyl is given in Table 7.

Contact of alkaline magma with xenolites of basalt and its tuff leads to the formation of a peraluminic assemblage of minerals: anorthoclase, cordierite-sekaninaite, phlogopite, muscovite-paragonite, corundum, hercynite, topaz, etc. This process takes place in a highly alkaline medium enriched with fluorine and carbon dioxide. The dispersed beryllium is leached from the primary rocks to form easily mobile complex compounds. Decomposition of these complexes 
and the formation of chrysoberyl occur in areas of fenites schistosity on the contact with the later biotite-orthoclase veins due to the lower alkalinity of solutions.

Table 7. Chemical composition of chrysoberyl.

\begin{tabular}{ccc}
\hline Sample $^{*}$ & 1, WCA & 2, EMP \\
\hline Component & \multicolumn{3}{c}{ wt \% } \\
\hline $\mathrm{V}_{2} \mathrm{O}_{5}$ & - & 0.32 \\
$\mathrm{SiO}_{2}$ & 0.80 & - \\
$\mathrm{TiO}_{2}$ & - & 0.41 \\
$\mathrm{Al}_{2} \mathrm{O}_{3}$ & 75.90 & 79.43 \\
$\mathrm{Fe}_{2} \mathrm{O}_{3}$ & 3.10 & - \\
$\mathrm{FeO}$ & - & 0.61 \\
$\mathrm{CaO}$ & 1.50 & - \\
$\mathrm{BeO}$ & 19.50 & $19.43_{\text {wet }}$ \\
\hline $\mathrm{Total}$ & 100.80 & 100.20
\end{tabular}

* Sample: 1-M.Vud'iavr, Khibiny [68], 2-Kaskasn'unchorr, Khibiny [47].

This mineral was further described in similar xenoliths from the foyaites of Mts Eveslogchorr, Kukisvumchorr and Kaskasn'unchorr, Khibiny massif [20,47]. The mineral occurs in veins of nepheline syenite and nepheline-sodalite syenite emplaced into biotite-feldspar hornfels. Chrysoberyl here forms tabular penetration trillings of pseudohexagonal habits and $1.5 \times 5 \mathrm{~mm}$ in size (Figure 9). The mineral is included into nepheline and sodalite. Chrysoberyl is rarely represented by short prismatic crystals of $1.5 \times 3 \mathrm{~cm}$ in size. Associated beryllium minerals are epididymite (Eveslogchorr) and gadolinite-(Ce) (Kaskasn'unchorr).

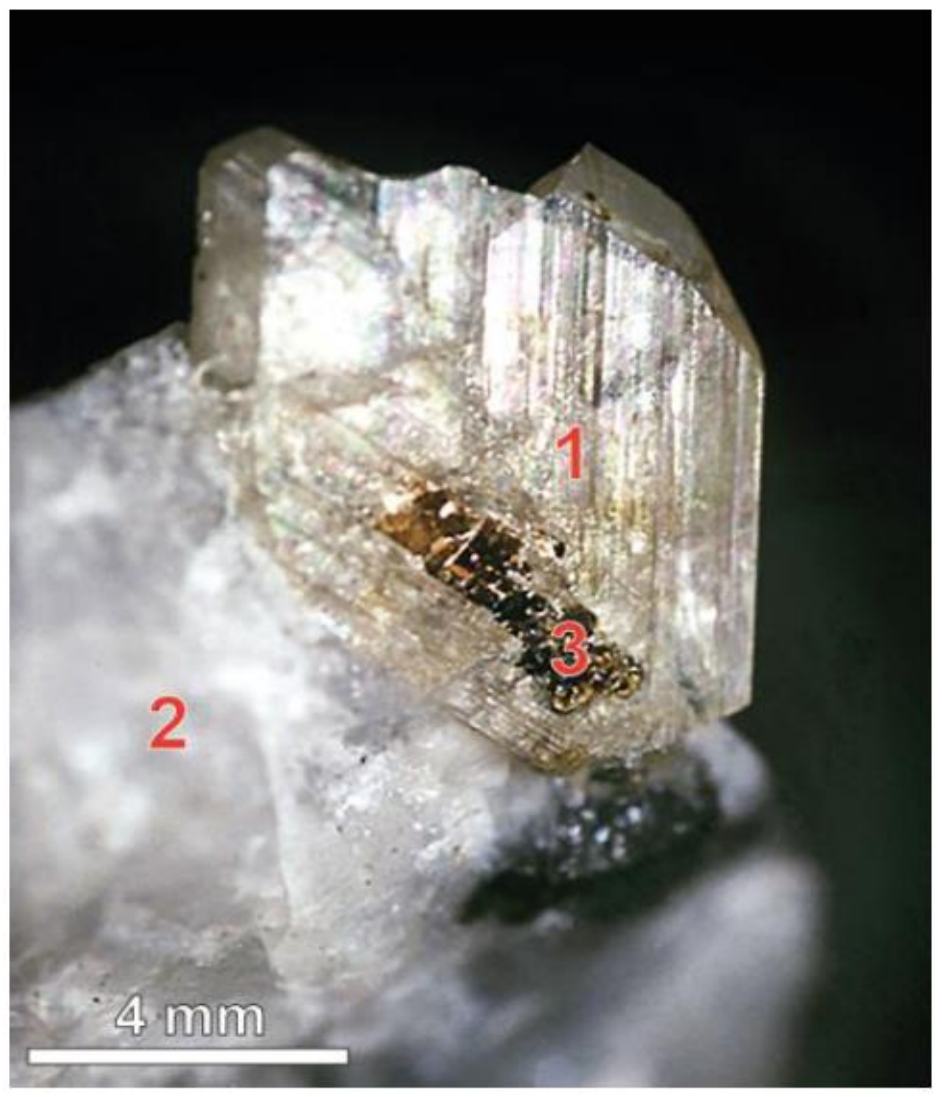

Figure 9. Crysoberyl twin (1) in a biotite-nepheline-anorthoclase pegmatite in fenite, Mt Kukisvumchorr, Khibiny. (2)-Nepheline, (3)-biotite. 
Danalite $\mathrm{Be}_{3} \mathrm{Fe}^{2+}{ }_{4}\left(\mathrm{SiO}_{4}\right)_{3} \mathrm{~S}$ occurs in quartz-feldspar vein emplaced in amphibolized metagabbro-anorthosites of the El'ozero rare-metal ore occurrence in the Keivy alkaline province $[69,70]$. The mineral is associated with quartz, allanite-(Ce) and thorite. Danalite forms tetrahedral crystals and, on rare occasions, tiny equidimensional grains. The length of the edge in the largest crystals reaches $2 \mathrm{~cm}$. Danalite includes numerous grains of quartz, albite, zircon and euxenite-(Y). The mineral identification was performed by XRD and wet chemical analysis. Danalite composition from El'ozero occurrence (Table 8) may be represented as a combination of the end members: $46.3 \%$ danalite $\left(\mathrm{Be}_{3} \mathrm{Fe}^{2+}{ }_{4}\left(\mathrm{SiO}_{4}\right)_{3} \mathrm{~S}\right), 36.5 \%$ genthelvite $\left(\mathrm{Be}_{3} \mathrm{Zn}_{4}\left(\mathrm{SiO}_{4}\right)_{3} \mathrm{~S}\right)$ and $17.2 \%$ helvine $\left(\mathrm{Be}_{3} \mathrm{Mn}^{2+}{ }_{4}\left(\mathrm{SiO}_{4}\right)_{3} \mathrm{~S}\right)$. Thus, danalite is characterized by broad isomorphic schemes, both isovalent $\left(\mathrm{Fe}^{2+} \rightleftarrows \mathrm{Zn}^{2+} ; \mathrm{Fe}^{2+} \rightleftarrows \mathrm{Mn}^{2+}\right)$ and heterovalent $\left(\mathrm{Be}^{2+} \rightleftarrows \mathrm{Al}^{3+}\right)$.

Table 8. Chemical composition of danalite.

\begin{tabular}{cc}
\hline Sample $^{*}$ & $\mathbf{1 , W C A}$ \\
\hline Component & wt \% \\
\hline $\mathrm{SiO}_{2}$ & 31.92 \\
$\mathrm{TiO}_{2}$ & 0.07 \\
$\mathrm{ZrO}_{2}$ & 0.14 \\
$\mathrm{Al}_{2} \mathrm{O}_{3}$ & 1.44 \\
$\mathrm{FeO}$ & 22.38 \\
$\mathrm{ZnO}$ & 19.99 \\
$\mathrm{MnO}$ & 8.15 \\
$\mathrm{MgO}$ & 0.10 \\
$\mathrm{CaO}$ & 0.50 \\
$\mathrm{BeO}$ & 12.44 \\
$\mathrm{H}_{2} \mathrm{O}^{-}$ & 0.17 \\
$\mathrm{H}_{2} \mathrm{O}^{+}$ & 0.69 \\
$\mathrm{~S}$ & 5.31 \\
$-\mathrm{O}=\mathrm{S}$ & 2.66 \\
\hline Total & 100.30 \\
\hline * Sample: 1 -El'ozero [69].
\end{tabular}

Eirikite $\mathrm{KNa}_{6} \mathrm{Be}_{2}\left(\mathrm{Si}_{15} \mathrm{Al}_{3}\right) \mathrm{O}_{39} \mathrm{~F}_{2}$. There are no published data on eirikite from Kola Peninsula. Nevertheless, Pekov [71] mentioned "potassium leifite" from Mt Alluaiv in Lovozero massif (Figure 1). However, the chemical composition of this mineral and FTIR spectra are similar to those of eirikite. In addition, leifite from Khibiny massif contains $1.48 \mathrm{wt} \%$ of $\mathrm{K}_{2} \mathrm{O}(0.45 \mathrm{apfu})$ [47]. The total content of $\mathrm{K}_{2} \mathrm{O}, \mathrm{Cs}_{2} \mathrm{O}$ and $\mathrm{Rb}_{2} \mathrm{O}$ is about $0.5 \mathrm{apfu}$ and can exceed this value, and then the formula of the mineral according to [72] can be recalculated as eirikite.

Epididymite $\mathrm{Na}_{2} \mathrm{Be}_{2} \mathrm{Si}_{6} \mathrm{O}_{15} \cdot \mathrm{H}_{2} \mathrm{O}$ was established simultaneously in the Khibiny and Lovozero massifs (Figure 2). Those were the first findings in the former Soviet Union [73]. In Lovozero, this mineral was found in a number of agpaitic pegmatites at Mts Karnasurt and Kuivchorr, while in Khibiny it was found in nepheline syenite pegmatites at Mt Yuksporr (Table 9). In fact, epididymite is a common mineral in nepheline syenite pegmatites worldwide. In addition to nepheline-bearing pegmatites, Lovozero epididymite is found also in nepheline-free albite veins with quartz and narsarsukite, which is a similar context to that found in the Narsarsuk pegmatites in Greenland, the type locality for epididymite. The mineral forms as individual euhedral platy and tabular crystals and pseudohexagonal tabular complex twins up to $2 \mathrm{~cm}$ size (Figure 10a).

Also, epididymite can form large (up to 20-30 cm) aggregates of different morphology: spherules, fibrous, fine-grained, chalky-like, clayey and dense porcelaine-like (Mts Karnasurt, Mannepahk, Sengischorr, Kuftnyun, etc.) and represents the most abundant beryllium mineral at the Lovozero massif $[32,61,74,75]$. Usually, epididymite grows after chkalovite (Figure 10b) and is replaced by a mineral sequence comprising first beryllite, then bertrandite and finally moraesite. 
Table 9. Chemical composition of epididymite.

\begin{tabular}{ccccc}
\hline Sample & 1, WCA & 2, WCA & 3, EMP & 4, EMP \\
\hline Component & \multicolumn{5}{c}{ wt \% } \\
\hline $\mathrm{SiO}_{2}$ & 72.60 & 70.70 & 71.82 & 74.27 \\
$\mathrm{Al}_{2} \mathrm{O}_{3}$ & 0.20 & 0.60 & - & 0.13 \\
$\mathrm{Fe}_{2} \mathrm{O}_{3}$ & 0.13 & - & - & - \\
$\mathrm{MgO}$ & 0.07 & 0.10 & - & - \\
$\mathrm{CaO}$ & 0.26 & 0.25 & - & - \\
$\mathrm{BeO}$ & 10.42 & 12.15 & $10.51_{\text {wet }}$ & - \\
$\mathrm{Na}_{2} \mathrm{O}$ & 12.63 & 11.81 & 11.72 & 11.91 \\
$\mathrm{~K}_{2} \mathrm{O}$ & 0.20 & - & 0.05 & 0.18 \\
$\mathrm{H}_{2} \mathrm{O}^{+}$ & 4.00 & 4.50 & $3.81_{\text {wet }}$ & - \\
\hline Total & 100.51 & 100.16 & 97.91 & 86.49 \\
\hline
\end{tabular}

* Sample: 1—Lovozero [73], 2-Khibiny [73], 3-Eveslogchorr, Khibiny [47], 4-Kovdor [33].

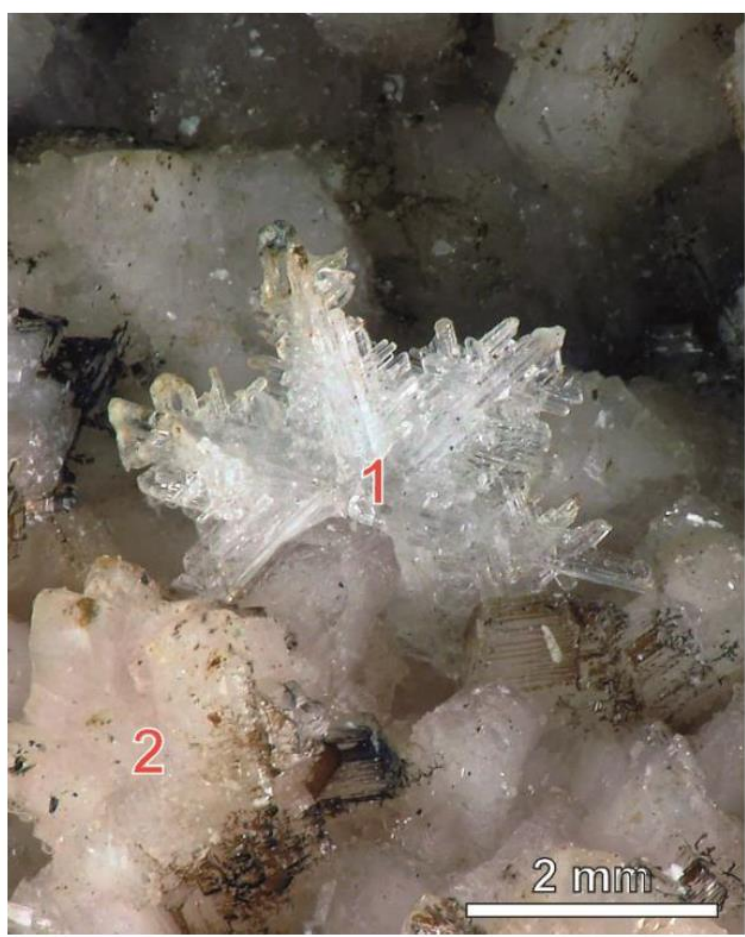

(a)

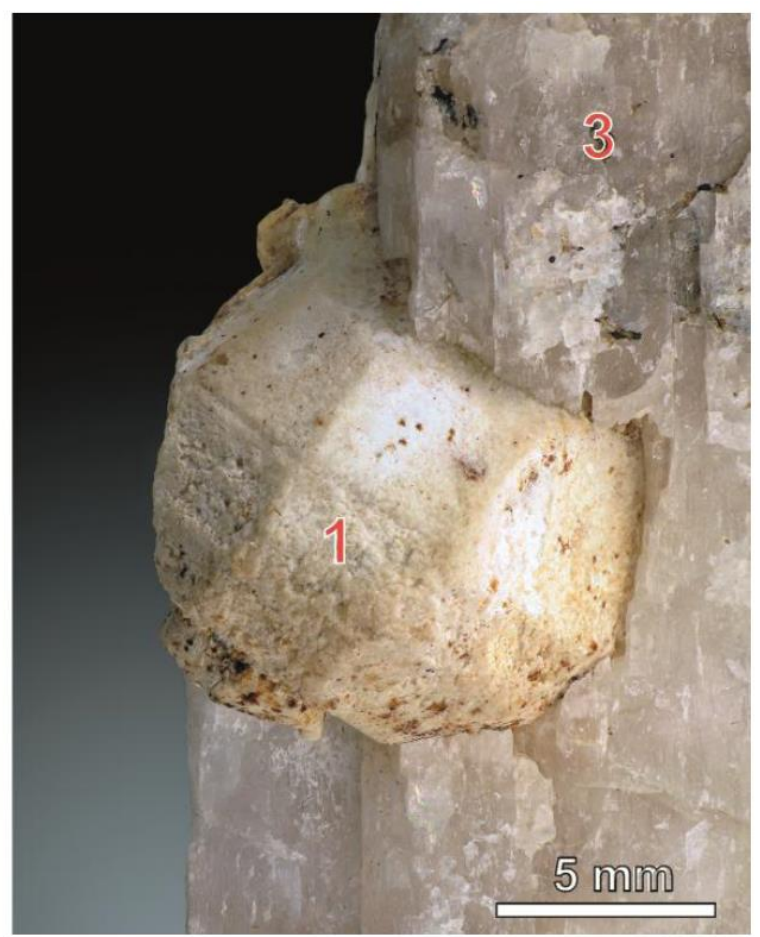

(b)

Figure 10. Epididymite (1): (a) skeletal trilling on albite (2), from an aegirine-feldspar lens in foyaite, Mt Kuftnyun, Lovozero; (b) complete pseudomorph after chkaklovite, in natrolite (3), from a microcline-natrolite lens in sodalite-nepheline syenite, Mt Karnasurt, Lovozero.

After the first occurrence in Mt Yuksporr, Khibiny massif, epididymite was also found in alkaline pegmatites of Mts Kukisvumchorr, Aikuaivenchorr and Partomchorr [20,47,76,77]. In the Aikuaivenchorr occurrence, epididymite forms complex tabular twins up to $1.2 \mathrm{~cm}$ in diameter and occurs in the albite zone together with catapleiite, aegirine, polylithionite and chabazite-Sr. Epididymite found in a central part of aegirine-feldspar pegmatite in gneissose foyaite of $\mathrm{Mt}$ Eveslogchorr is associated with leifite. Here, epididymite grows as large aggregates up to $20 \mathrm{~cm}$ and it is represented by two morphological types: (a) as fine-grained aggregates and (b) as druses of flattened crystals. The mineral can also be a product of alteration of tugtupite, as was established in another natrolite-feldspar vein in Mt Eveslogchorr [20,47]. 
Epididymite is the unique beryllium mineral known from Kovdor alkaline-ultrabasic massif [33]. It was found in the cavities in pyroxenised fenite near the contact with phoscorites. Crystals of epididymite grow on albite and aegirine-augite along with saponite, labuntsovite and catapleiite.

The existence of a dimorphism between epididymite and eudidymite was established in 1972 [78] and the crystal-chemical formula of $\mathrm{H}_{2} \mathrm{O}$-containing epididymite was proposed. However, many authors continued to use the formulae with $\mathrm{OH}$-groups until 2008 [79] due to the unusually high dehydration temperature $\left(810-830{ }^{\circ} \mathrm{C}\right.$ according [73]).

Eudidymite $\mathrm{Na}_{2} \mathrm{Be}_{2} \mathrm{Si}_{6} \mathrm{O}_{15} \cdot \mathrm{H}_{2} \mathrm{O}$ was found in albitites of Mt Flora, Lovozero massif (Figure 2), in association with epididymite and narsarsukite [73]. Later, eudidymite was found in the central part of the "Natrolite Stock" pegmatite in sodalite-nepheline syenite of Mt Karnasurt, where where it forms characteristic twins up to $5 \mathrm{~mm}$ in diameter (Figure 11) in association with epididymite and leifite [80]. Similar twins of eudidymite associated with epididymite occur in and aegirine-feldspar pegmatite in eudialyte lujavrite of Mt Mannepakh.

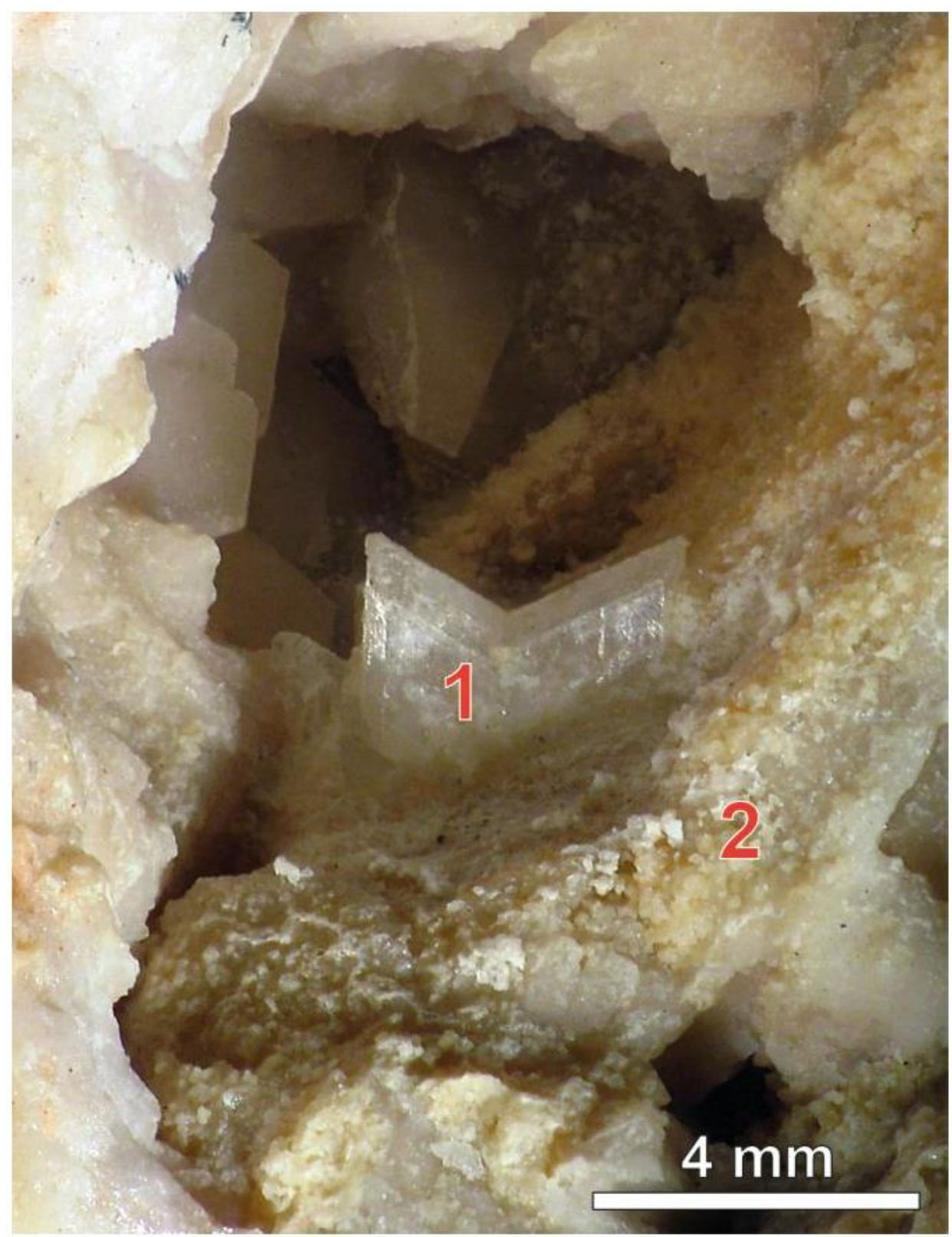

Figure 11. Eudydimite twin (1) on albite (2), from an aegirine-feldspar lens in sodalite-nepheline syenite, Mt Karnasurt, Lovozero. 
"Eudidymite" was mentioned from pegmatite of Mt Partomchorr, Khibiny massif [79], but later was discredited and identified as epididymite [47]. Thus, the occurrences of eudidymite in Khibiny massif include the feldspar rock in Mt Restinjun and natrolitized aegirine-nepheline-microcline pegmatite in urtite of Mt Kukisvumchorr [20], where it forms colorless flattened-prismatic crystals and sheaf-like aggregates up to $5 \mathrm{~mm}$ long in close association with epididymite.

Gadolinite-(Ce) $\mathrm{Ce}_{2} \mathrm{Fe}^{2+} \mathrm{Be}_{2} \mathrm{O}_{2}\left(\mathrm{SiO}_{4}\right)_{2}$ is found in sodalite-biotite-orthoclase veinlets within hornfels at Mts Kukisvumchorr, Rischorr and Kaskasn'unchorr, the Khibiny massif (Figure 2) as dark green irregularly-shaped grains up to $2 \mathrm{~mm}$ in diameter in the interstices of nepheline and potassium feldspar [20,46]. Fayalite, zirconolite, fluorcalciobritholite, zircon, molybdenite, monazite-(Ce), löllingite, graphite, and chrysoberyl are the characteristic associated minerals. Gadolinite-(Ce) is metamict and yields the distinct X-ray powder pattern after heating up to $900{ }^{\circ} \mathrm{C}$.

Also, gadolinite-(Ce) is a relatively common mineral in quartz-epidote metasomatites of the El'ozero rare-metal occurrence (Figure 1), Keivy alkaline province [28]. Gadolinite-(Ce) forms anhedral elongated grains up to $100 \mu \mathrm{m}$ rimmed by hingganite-(Ce) (Figure 12a). The grains are clearly emanating from chevkinite-(Ce). Areas between the grains are composed of ferriallanite-(Ce), ilmenite and titanite. Gadolinite-(Ce) from El'ozero was diagnosed only on the results of microprobe analyses without beryllium determination (Table 10). It is shown that the measured and calculated composition of gadolinite-(Ce) is cation deficient in the positions of $\mathrm{Ce}$ and Fe. Occurrence has not been confirmed by XRD due to gadolinite-(Ce) metamict state. The mineral crystallizes during the late stages of fluid-induced alteration of chevkinite-(Ce).

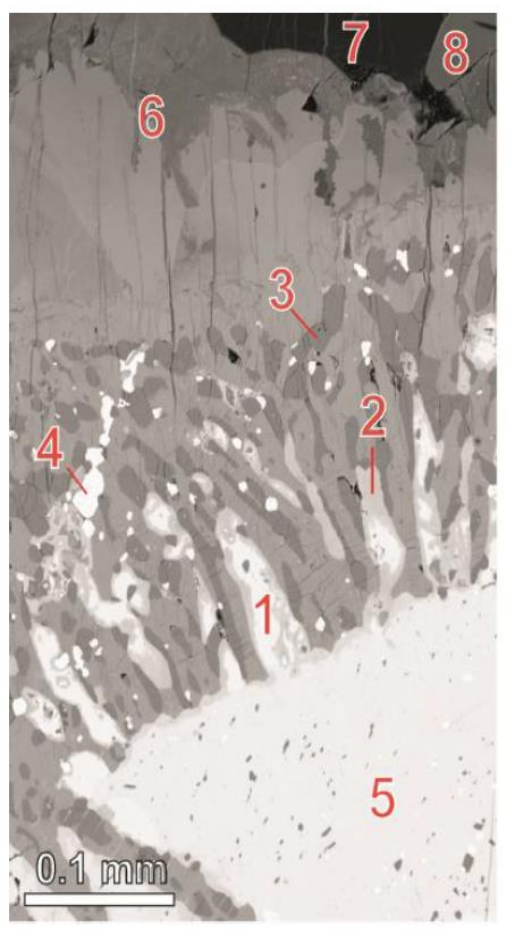

(a)

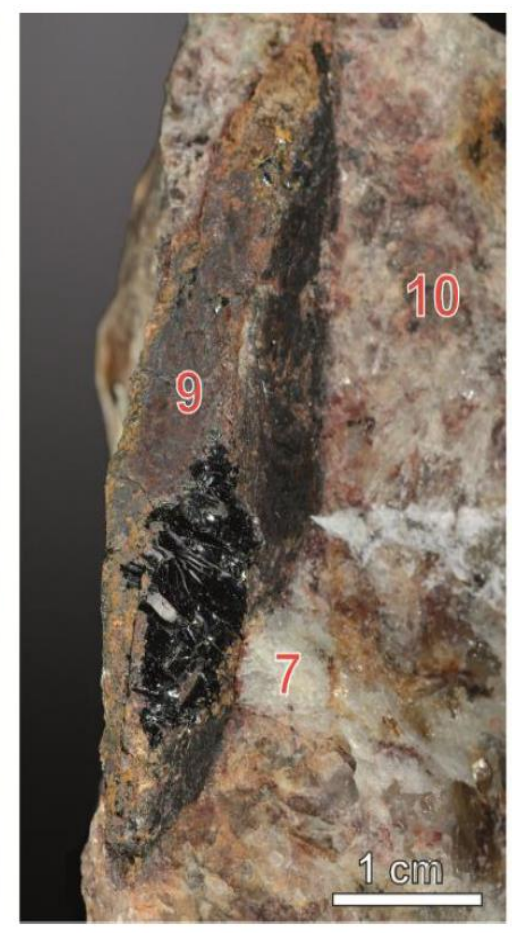

(b)

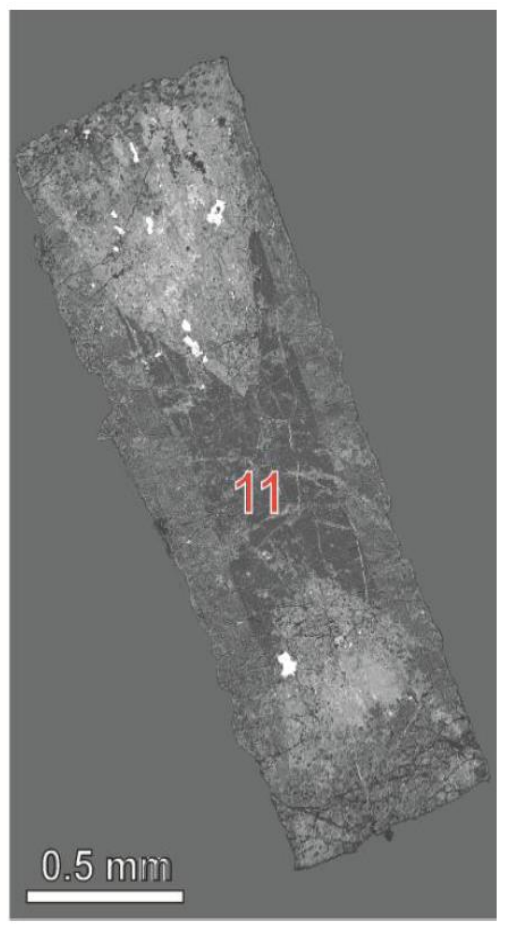

(c)

Figure 12. Gadolinite-(Ce), gadolinite-( $\mathrm{Y})$ and hingganite-( $\mathrm{Y})$ : (a) corona-like aggregates of gadolinite-(Ce) (1), hingganite-(Ce) (2), ilmenite (3) and thorite (4) around chevkinite-(Ce) inclusion (5) in ferriallanite-(Ce) (6), with quartz (7) and titanite (8), from quartz-epidote metasomatite of the El'ozero deposit, Keivy; (b) crystal of gadolinite-(Y) (9) in quartz (7) and microcline (10), from Mt Ploskaya, Keivy; (c) sectoral crystal of hingganite-(Y) (11), from alkaline granite pegmatite of the Belye Tundry massif, Keivy. 
Table 10. Chemical composition of gadolinite-(Ce).

\begin{tabular}{|c|c|c|}
\hline \multirow{2}{*}{$\begin{array}{c}\text { Sample }^{*} \\
\text { Component }\end{array}$} & 1, EMP & $2, \mathrm{EMP}$ \\
\hline & \multicolumn{2}{|c|}{ wt $\%$} \\
\hline $\mathrm{SiO}_{2}$ & 21.14 & 21.47 \\
\hline $\mathrm{TiO}_{2}$ & - & 0.29 \\
\hline $\mathrm{ThO}_{2}$ & 4.75 & 4.12 \\
\hline $\mathrm{UO}_{2}$ & - & 0.44 \\
\hline $\mathrm{Y}_{2} \mathrm{O}_{3}$ & 0.84 & 5.44 \\
\hline $\mathrm{La}_{2} \mathrm{O}_{3}$ & 18.41 & 5.80 \\
\hline $\mathrm{Ce}_{2} \mathrm{O}_{3}$ & 25.36 & 19.37 \\
\hline $\mathrm{Pr}_{2} \mathrm{O}_{3}$ & 1.19 & 2.73 \\
\hline $\mathrm{Nd}_{2} \mathrm{O}_{3}$ & 3.14 & 11.39 \\
\hline $\mathrm{Sm}_{2} \mathrm{O}_{3}$ & 0.40 & 3.31 \\
\hline $\mathrm{Gd}_{2} \mathrm{O}_{3}$ & - & 2.36 \\
\hline $\mathrm{Fe}_{2} \mathrm{O}_{3}$ & 12.59 & - \\
\hline $\mathrm{BeO}$ & $9.99_{\text {wet }}$ & $8.94_{\text {calc }}$ \\
\hline $\mathrm{CaO}$ & 1.82 & 0.83 \\
\hline $\mathrm{MnO}$ & 0.65 & - \\
\hline $\mathrm{FeO}$ & - & $11.68^{* *}$ \\
\hline Total & 100.28 & 98.17 \\
\hline
\end{tabular}

Gadolinite-( $(\mathrm{Y}) \mathrm{Y}_{2} \mathrm{Fe}^{2+} \mathrm{Be}_{2} \mathrm{O}_{2}\left(\mathrm{SiO}_{4}\right)_{2}$. The first findings of gadolinite- $(\mathrm{Y})$ on the Kola Peninsula were made by Belkov [81] in amazonite pegmatites related to peralkaline granites of Western Keivy massif of Keivy alkaline province and of Kanozero massif (Figure 1). Morphology and abundance of the mineral was noted to depend on pegmatite zones. As a whole, numerous prismatic or ellipsoidal gadolinite- $(\mathrm{Y})$ crystals up to $5-8 \mathrm{~cm}$ in length always coated by alteration crusts, composing from hydroxides of Fe and REE (Figure 12b), are usual for border zone (selvage) of pegmatites. Crystal accumulations or, on the contrary, sporadic crystals are usual for albitized pegmatite zones. It is assumed that gadolinite-( $(Y)$ in the selvages has crystallized at an earlier high-temperature stage, and in the albitized zones it crystallized at a later hydrothermal stage [81]. Another origin of gadolinite-(Y), namely metasomatic, is assumed by Lunz [82]. Chemical composition of gadolinite-(Y) is close to stoichiometric formulae with insignificant deficiency in Fe position, especially for Kanozero samples [81] (Table 11).

Gadolinite-(Y) was found also in peralkaline granite veins of the El'ozero occurrence, Keivy alkaline province [84]. The chemical composition of minerals stands out with high content of $\mathrm{Ca}$ and $\mathrm{Al}$, and lower content of Be.

At last, gadolinite-( $(\mathrm{Y})$ is found in intragranite pegmatites of peralkaline granite massifs of Keivy alkaline province. The pegmatites are assumed as the earliest postmagmatic product of peralkaline granites [85]. The mineral is represented by thick tabular, prismatic crystals and anhedral grains up to $5 \mathrm{~mm}$ in size. Gadolinite- $(\mathrm{Y})$ is associated with hingganite- $(\mathrm{Y})$, fergusonite- $(\mathrm{Y})$, tengerite- $(\mathrm{Y})$, britholite group minerals, and astrophyllite. Gadolinite- $(\mathrm{Y})$ from intragranite pegmatites differs from many other occurrences by its crystalline state. 
Table 11. Chemical composition of gadolinite-(Y).

\begin{tabular}{|c|c|c|c|}
\hline Sample * & 1, EMP & $2, \mathrm{WCA}$ & 3, EMP \\
\hline Component & & wt $\%$ & \\
\hline $\mathrm{U}_{3} \mathrm{O}_{8}$ & - & 0.07 & - \\
\hline $\mathrm{ThO}_{2}$ & 0.36 & 0.36 & 0.39 \\
\hline $\mathrm{Al}_{2} \mathrm{O}_{3}$ & - & 2.00 & 0.00 \\
\hline $\mathrm{Fe}_{2} \mathrm{O}_{3}$ & - & 1.27 & - \\
\hline $\mathrm{Y}_{2} \mathrm{O}_{3}$ & 27.52 & - & 16.46 \\
\hline $\mathrm{La}_{2} \mathrm{O}_{3}$ & 1.65 & & 2.75 \\
\hline $\mathrm{Ce}_{2} \mathrm{O}_{3}$ & 5.52 & & 11.42 \\
\hline $\mathrm{Pr}_{2} \mathrm{O}_{3}$ & 0.65 & & 1.14 \\
\hline $\mathrm{Nd}_{2} \mathrm{O}_{3}$ & 1.83 & & 5.76 \\
\hline $\mathrm{Sm}_{2} \mathrm{O}_{3}$ & 0.47 & & 2.19 \\
\hline $\mathrm{Eu}_{2} \mathrm{O}_{3}$ & 0.12 & & - \\
\hline $\mathrm{Gd}_{2} \mathrm{O}_{3}$ & 0.60 & & 3.69 \\
\hline $\mathrm{Tb}_{2} \mathrm{O}_{3}$ & 0.15 & $K E E_{2} \mathrm{O}_{3}=48.34$ & 0.56 \\
\hline $\mathrm{Dy}_{2} \mathrm{O}_{3}$ & 2.54 & & 4.05 \\
\hline $\mathrm{Ho}_{2} \mathrm{O}_{3}$ & 0.75 & & 0.65 \\
\hline $\mathrm{Er}_{2} \mathrm{O}_{3}$ & 3.31 & & 1.61 \\
\hline $\mathrm{Tm}_{2} \mathrm{O}_{3}$ & 0.55 & & 0.00 \\
\hline $\mathrm{Yb}_{2} \mathrm{O}_{3}$ & 4.02 & & 0.37 \\
\hline $\mathrm{Lu}_{2} \mathrm{O}_{3}$ & 0.41 & & - \\
\hline $\mathrm{SiO}_{2}$ & 23.96 & 24.81 & 23.09 \\
\hline $\mathrm{TiO}_{2}$ & - & 0.22 & - \\
\hline $\mathrm{BeO}$ & $9.97_{\mathrm{calc}}$ & 9.13 & $9.61_{\text {calc }}$ \\
\hline $\mathrm{PbO}$ & - & 0.12 & - \\
\hline $\mathrm{FeO}$ & 10.15 * & 9.79 & $9.83^{* *}$ \\
\hline $\mathrm{ZnO}$ & - & - & 0.07 \\
\hline $\mathrm{MnO}$ & 0.28 & 0.29 & 0.36 \\
\hline $\mathrm{MgO}$ & - & 0.25 & - \\
\hline $\mathrm{CaO}$ & 0.26 & 2.64 & 0.37 \\
\hline $\mathrm{H}_{2} \mathrm{O}^{+}$ & - & 0.71 & - \\
\hline Total & 95.07 & 100.09 & 94.37 \\
\hline
\end{tabular}

* Sample: 1-Kanozero [83], 2-El'ozero [84], 3-Keivy [85]. ** all $\mathrm{Fe}$ as $\mathrm{Fe}^{2+}$. In sample 3: $7.11 \mathrm{wt} \% \mathrm{FeO}, 2.90 \mathrm{wt} \%$ $\mathrm{Fe}_{2} \mathrm{O}_{3}$ (wet chemistry analysis, analyst L.I. Konstantinova, KSC RAS); 9.80 wt \% BeO, 0.20 wt \% $\mathrm{B}_{2} \mathrm{O}_{3}$ (ICP-MS, analyst S.V. Drogobuzhskaya, ICT KSC RAS). $\mathrm{BeO}_{\text {calc }}$ calculated from the atomic ratio Si:Be = 1:1.

Gadolinite-( $\mathrm{Y})$ is one of the main $\mathrm{Y}$ and REE carriers in pegmatites of peralkaline granite of Kola Peninsula [83]. There are differences in concentration of individual REE in gadolinite-(Y) from peralkaline granite veins, amazonite pegmatites and intragranite pegmatites [85-87]. Based on the REE distribution, it is assumed that in intragranite pegmatites the mineral crystallizes during the late magmatic/pegmatitic stage, while in amazonite pegmatites it crystallizes during the hydrothermal stage [85].

Genthelvite $\mathrm{Be}_{3} \mathrm{Zn}_{4}\left(\mathrm{SiO}_{4}\right)_{3} \mathrm{~S}$. The mineral was found [88] in the feldspar pegmatites located in a small outcrop of augite-porphyrites on the roof of nepheline syenite intrusion, Mt Flora, Lovozero massif (Figure 2). It was the first finding of genthelvite within the former Soviet Union. The mineral forms anhedral $1 \times 2 \mathrm{~mm}$ grains, rarely up to $5 \times 10 \mathrm{~mm}$. Its color changes from green to colorless. High MnO contents (up to $10.21 \mathrm{wt} \%$ ) are determined in this mineral (Table 12). Genthelvite is associated with $\mathrm{Mn}$-bearing ilmenite and zircon. Its formation is related to input of $\mathrm{Fe}, \mathrm{Mn}, \mathrm{Mg}$ from hosting basic rocks into alkaline pegmatitic melt/solution. In that case genthelvite can form instead of Be silicates of sodium and calcium (leucophanite, meliphanite, epididymite, eudidymite, chkalovite), typical for alkaline pegmatites. 
Table 12. Chemical composition of genthelvite.

\begin{tabular}{ccc}
\hline Sample & 1, WCA & 2, WCA \\
\hline Component & \multicolumn{3}{c}{ wt \% } \\
\hline $\mathrm{SiO}_{2}$ & 27.35 & 32.08 \\
$\mathrm{Fe}_{2} \mathrm{O}_{3}$ & 6.70 & 0.78 \\
$\mathrm{Y}_{2} \mathrm{O}_{3}$ & - & \\
$\mathrm{Yb}_{2} \mathrm{O}_{3}$ & - & 0.32 \\
$\mathrm{Ce}_{2} \mathrm{O}_{3}$ & - & \\
$\mathrm{FeO}$ & - & 13.71 \\
$\mathrm{MnO}$ & 10.21 & 5.21 \\
$\mathrm{ZnO}$ & 40.00 & 33.54 \\
$\mathrm{CaO}$ & - & 0.28 \\
$\mathrm{SrO}$ & - & 11.71 \\
$\mathrm{BeO}$ & 12.00 & 0.12 \\
$\mathrm{Na} \mathrm{O}_{2} \mathrm{O}$ & - & 0.12 \\
$\mathrm{~K}_{2} \mathrm{O}$ & - & 5.49 \\
$\mathrm{H}_{2} \mathrm{O}^{+}$ & - & 2.78 \\
$\mathrm{~S}$ & 5.74 & 100.58 \\
$-\mathrm{O}=\mathrm{S}$ & 2.87 & \\
$\mathrm{Total}$ & 99.13 & \\
\hline
\end{tabular}

* Sample: 1-Mt Flora, Lovozero [88], 2-Keivy alkaline province [89].

Genthelvite occurs also in amazonite pegmatites of the Keivy alkaline province [89,90], where it usually forms anhedral 2-3 mm grains and their aggregates. Vasiliev [89] observed these anhedral grains within beryl crystals. In amazonite pegmatite of Mt Rovgora, genthelvite forms well shaped crystals (Figure 13) and its debris reaches up to $8 \times 12 \mathrm{~cm}$ [90]. Their chemical analysis returns on significant variations of Fe and $\mathrm{Mn}$, which can be related to influence of pegmatite' host rocks [70]. It is suggested that genthelvite is of metasomatic origin and formed during albitization of pegmatites [89].

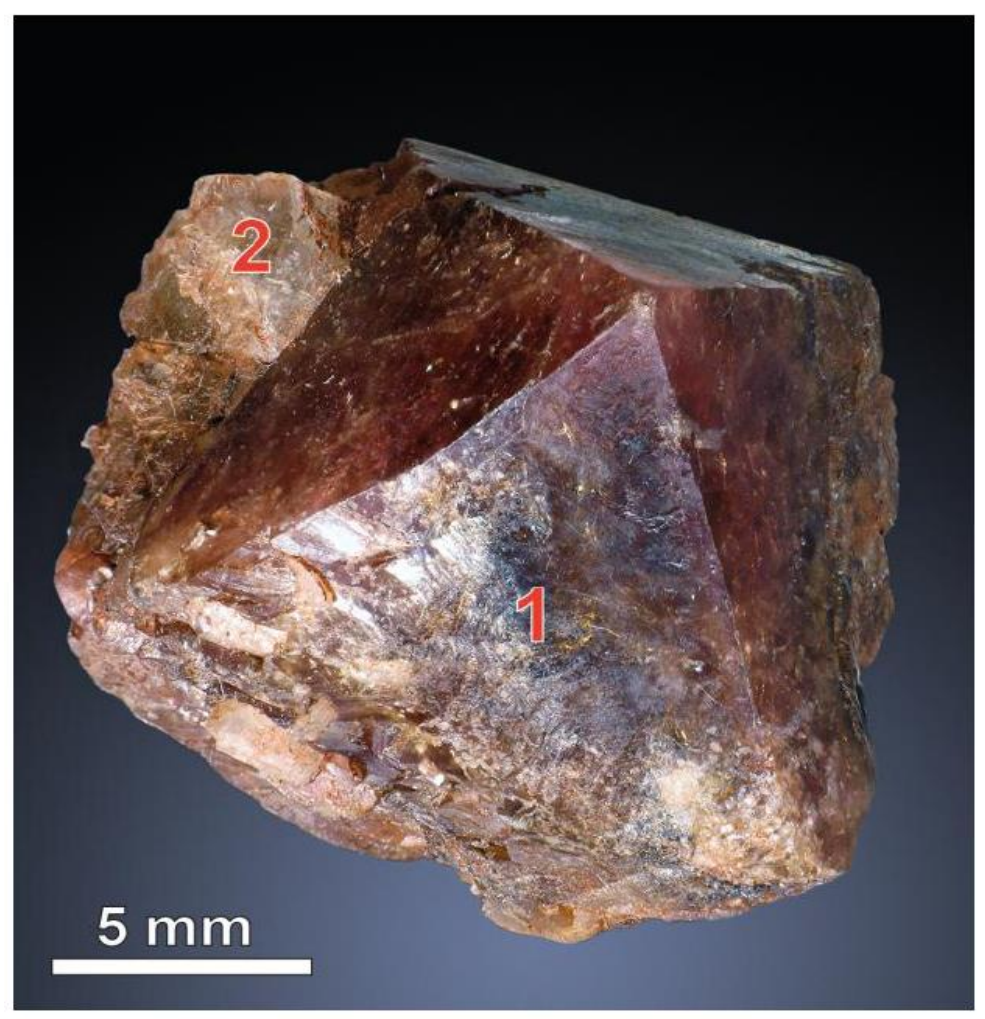

Figure 13. Genthelvite crystal (1), with albite (2), from the amazonite pegmatite, Mt Rovgora, Keivy. 
Hingganite-(Ce) $\mathrm{BeCe}\left(\mathrm{SiO}_{4}\right)(\mathrm{OH})$ is found [28] in quartz-epidote metasomatic rocks of the El'ozero rare-metal occurrence in the Keivy alkaline province (Figure 1). The mineral replaces gadolinite-(Ce) (Figure 12a). Chemical composition of hingganite-(Ce) from this locality (Table 13) is similar to those from other occurrences $[85,91]$, with the difference of higher $\mathrm{CaO}$ values (up to $4.4 \mathrm{wt} \%)$. The mineral has not been confirmed by X-ray studies.

Table 13. Chemical composition of hingganite-(Ce).

\begin{tabular}{|c|c|}
\hline \multirow{3}{*}{$\begin{array}{c}\text { Sample }{ }^{*} \\
\text { Component }\end{array}$} & \multirow{3}{*}{$\begin{array}{c}\text { 1, EMP } \\
\text { wt } \%\end{array}$} \\
\hline & \\
\hline & \\
\hline $\mathrm{P}_{2} \mathrm{O}_{5}$ & 0.05 \\
\hline $\mathrm{Ta}_{2} \mathrm{O}_{5}$ & 0.06 \\
\hline $\mathrm{SiO}_{2}$ & 25.30 \\
\hline $\mathrm{TiO}_{2}$ & 0.32 \\
\hline $\mathrm{ThO}_{2}$ & 3.38 \\
\hline $\mathrm{UO}_{2}$ & 0.09 \\
\hline $\mathrm{Al}_{2} \mathrm{O}_{3}$ & 0.80 \\
\hline $\mathrm{Y}_{2} \mathrm{O}_{3}$ & 5.07 \\
\hline $\mathrm{La}_{2} \mathrm{O}_{3}$ & 5.27 \\
\hline $\mathrm{Ce}_{2} \mathrm{O}_{3}$ & 17.13 \\
\hline $\mathrm{Pr}_{2} \mathrm{O}_{3}$ & 2.38 \\
\hline $\mathrm{Nd}_{2} \mathrm{O}_{3}$ & 10.31 \\
\hline $\mathrm{Sm}_{2} \mathrm{O}_{3}$ & 2.68 \\
\hline $\mathrm{Gd}_{2} \mathrm{O}_{3}$ & 2.02 \\
\hline $\mathrm{Tb}_{2} \mathrm{O}_{3}$ & 0.24 \\
\hline $\mathrm{Dy}_{2} \mathrm{O}_{3}$ & 0.86 \\
\hline $\mathrm{Yb}_{2} \mathrm{O}_{3}$ & 0.25 \\
\hline $\mathrm{BeO}$ & $10.53_{\text {calc }}$ \\
\hline $\mathrm{CaO}$ & 3.41 \\
\hline $\mathrm{MnO}$ & 0.23 \\
\hline $\mathrm{FeO}$ & $6.07^{* *}$ \\
\hline $\mathrm{PbO}$ & 0.26 \\
\hline Total & 96.60 \\
\hline
\end{tabular}

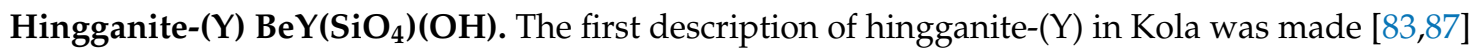
in the amazonite pegmatite of Mt Ploskaya, the Keivy alkaline province (Figure 1), where it forms radiated aggregates of acicular crystals. Hingganite-( $(\mathrm{Y})$ is colorless or has white color.

The intragranite pegmatites in the Keivy alkaline province were the second occurrence of this mineral [85]. Hingganite-(Y) here is represented by sectoral prismatic (Figure 12c) and pseudo-rhombohedral crystals and by anhedral grains. Hingganite- $(\mathrm{Y})$ from intragranite pegmatite has significantly higher Fe content comparing to that from amazonite pegmatites (Table 14). Its high content of $\mathrm{CaO}$ (up to $5 \mathrm{wt} \%$ ) allows suggest the possible transition to hypothetic "calciohingganite", by analogy with the series "gadolinite" - synthetic calciogadolinite. REE distribution in hingganite-(Y) from intragranite pegmatites is different from those in amazonite pegmatites and characterized by higher LREE, lower HREE, and weak positive slope of chondrite-normalized values $\left(\mathrm{LREE}_{\mathrm{n}} / \mathrm{HREE}_{\mathrm{n}}=\right.$ 0.7). Also, hingganite-(Y) from intragranite pegmatites shows the larger cell parameters $(\AA): a=10.05$, $b=7.72, c=4.76$. However, the link between cell parameters and content of $\mathrm{Y}, \mathrm{REE}, \mathrm{Ca}, \mathrm{Fe}$ is not well established [85]. 
Table 14. Chemical composition of hingganite-(Y).

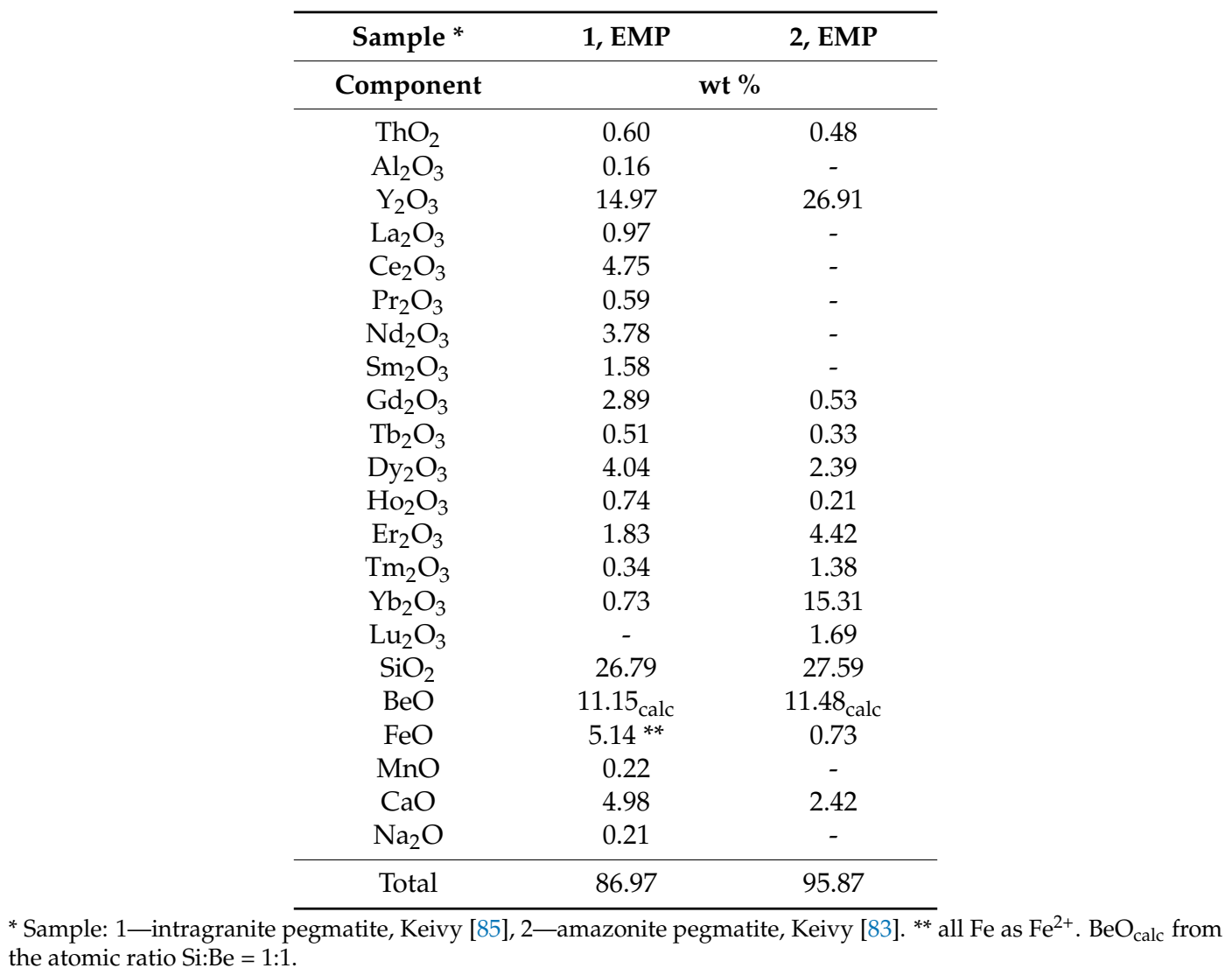

Hingganite-( $\mathrm{Yb}) \mathbf{B e Y b}\left(\mathrm{SiO}_{4}\right)(\mathrm{OH})$ was described [45] as a new mineral in amazonite pegmatites of the Keivy alkaline province (Figure 1). The mineral forms radiated aggregates made up by tiny needles of 0.1-0.2 mm in width, covering on "plumbomicrolite" crystals or growing in interstices of fluorite. The hingganite- $(\mathrm{Yb})$ has lower Ca content (Table 15) and nearly complete absence of Fe comparatively to composition of hingganite- $(\mathrm{Y})$ from amazonite pegmatites. Both minerals are characterized by different REE patterns. It is suggested that hingganite- $(\mathrm{Yb})$ is one of the latest minerals in amazonite pegmatite and crystallized due to the hydrothermal/metasomatical alteration of gadolinite- $(\mathrm{Y})$ combined with selective enrichment of solutions by ytterbium [45]. A possible new mineral species, an ytterbium sorosilicate with thortveitite-like structure is associated with hingganite- $(\mathrm{Yb})$.

Leifite $\mathrm{Na}_{7} \mathrm{Be}_{2}\left(\mathrm{Si}_{15} \mathrm{Al}_{3}\right) \mathrm{O}_{39}(\mathrm{~F}, \mathrm{OH})_{2}$ was firstly noted at the Kola Peninsula in [92], although it was misidentified as a new mineral and described under the name "karpinskiite". The mineral occurs in natrolite-feldspar lens close to the pegmatite "Natrolite Stock", Mt Karnasurt, Lovozero massif (Figure 2). The lens consists mainly of coarse natrolite, albite, potassium feldspar and chabazite. eifite forms white or colorless, thin prismatic to fibrous crystals, assembled in radially-fibrous rosettes (Figure 14). Leifite occurs in cavities and cracks cutting granular albite, and rarely natrolite. Micheelsen and Petersen re-investigated the material and established that " $X$-ray data on karpinskiite show that it is a mixture of leifite and a zinc-bearing clay of the montmorillonite group". The redefinition of leifite and the discrediting of karpinskiite were approved before publication by the commission on New Minerals and Mineral Names, IMA [93]. 
Table 15. Chemical composition of hingganite-( $\mathrm{Yb})$.

\begin{tabular}{cc}
\hline Sample $^{*}$ & 1, EMP \\
\hline Component & wt \% \\
\hline $\mathrm{Y}_{2} \mathrm{O}_{3}$ & 8.56 \\
$\mathrm{Gd}_{2} \mathrm{O}_{3}$ & 0.11 \\
$\mathrm{~Tb}_{2} \mathrm{O}_{3}$ & 0.05 \\
$\mathrm{Dy}_{2} \mathrm{O}_{3}$ & 2.47 \\
$\mathrm{Ho}_{2} \mathrm{O}_{3}$ & 1.03 \\
$\mathrm{Er}_{2} \mathrm{O}_{3}$ & 8.22 \\
$\mathrm{Tm}_{2} \mathrm{O}_{3}$ & 3.10 \\
$\mathrm{Yb}_{2} \mathrm{O}_{3}$ & 34.07 \\
$\mathrm{Lu}_{2} \mathrm{O}_{3}$ & 4.50 \\
$\mathrm{SiO}_{2}$ & 22.11 \\
$\mathrm{BeO}$ & 10.90 \\
$\mathrm{CaO}$ & 1.14 \\
\hline $\mathrm{Total}$ & 96.26 \\
\hline
\end{tabular}

* Sample: 1-amazonite pegmatite, Keivy [45].

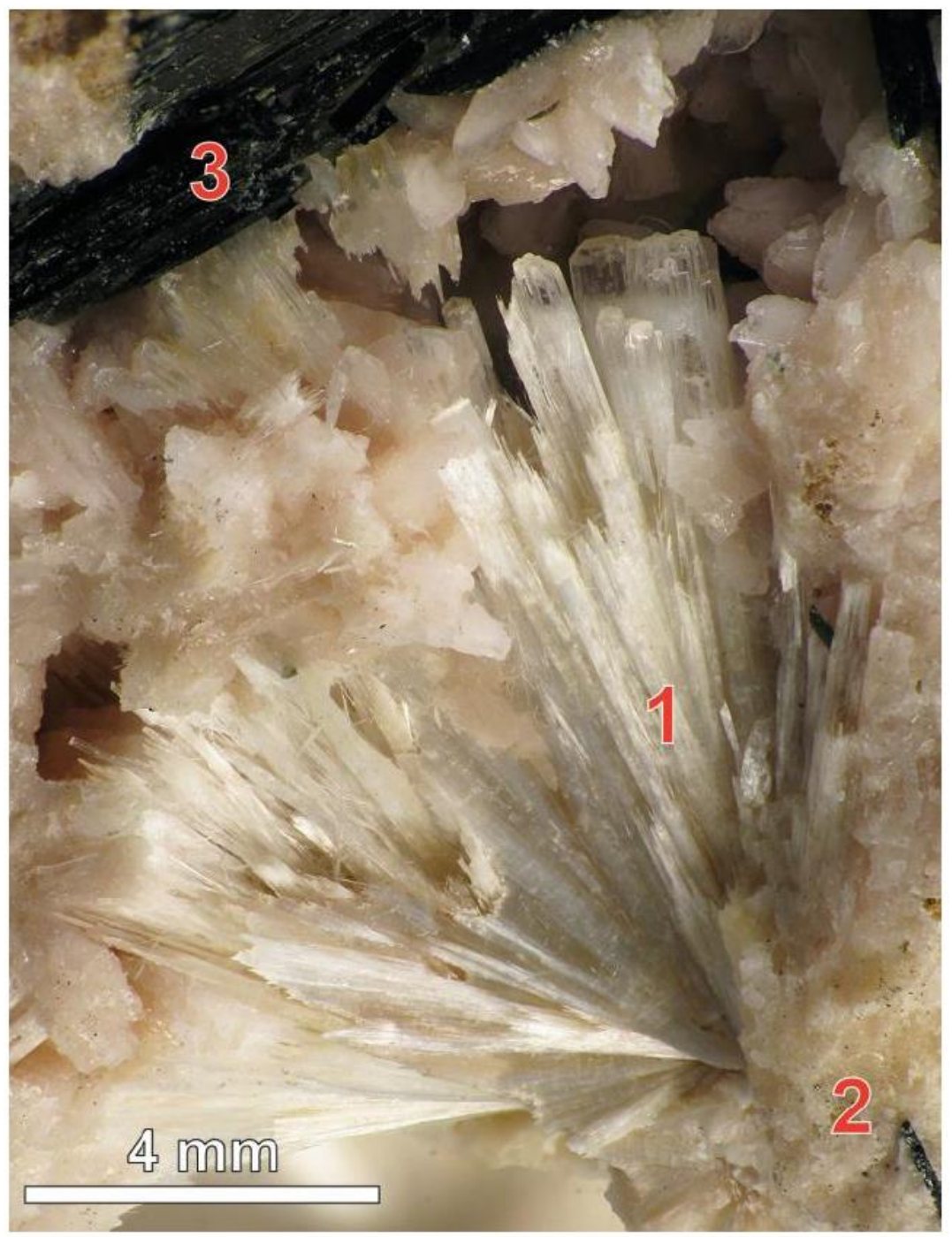

Figure 14. Radiated aggregate of leifite (1) on albite (2), with aegirine (3), from an aegirine-feldspar lens in sodalite-nepheline syenite, Mt Karnasurt, Lovozero. 
Leifite was subsequently discovered in other Lovozero pegmatites, in particular [94] and in the "Shomiokitovoe" and "Nastrofitovoe" pegmatites [32].

Leifite was found in the Khibiny massif (Figure 2) in pegmatite veins, up to $2 \mathrm{~m}$ thick, cutting gneissose foyaite in the Mt Eveslogchorr [20,31]. Detailed studies demonstrated that the mineral occurs in the cavities of rose albite, forming white prismatic crystals (1-2 mm long) and spherules, up to $6 \mathrm{~mm}$ in diameter, associated with epididymite [47]. Also, flat white spherulites of leifite (up to $4 \mathrm{~mm}$ in diameter) are found in analcime-microcline veinlet in urtite of Mt Kukisvumchorr [20].

The mineral contains high tenors of $\mathrm{Cs}_{2} \mathrm{O}, 0.88 \mathrm{wt} \%$, and $\mathrm{Rb}_{2} \mathrm{O}, 1.77 \mathrm{wt} \%$ (Table 16), and can be regarded as the main concentrator of these elements [71].

Table 16. Chemical composition of leifite.

\begin{tabular}{ccccc}
\hline Sample * & 1, EMP & 2, WCA & 3, WCA & 4, EMP \\
\hline Component & \multicolumn{5}{c}{ wt \% } \\
\hline $\mathrm{SiO}_{2}$ & 69.65 & 56.68 & 62.00 & 64.13 \\
$\mathrm{Al}_{2} \mathrm{O}_{3}$ & 8.05 & 16.40 & 16.53 & 10.32 \\
$\mathrm{Fe}_{2} \mathrm{O}_{3}$ & - & 0.06 & - & - \\
$\mathrm{ZnO}$ & 0.71 & 3.26 & 0.07 & - \\
$\mathrm{MgO}$ & - & 0.78 & - & - \\
$\mathrm{MnO}$ & - & - & 0.41 & - \\
$\mathrm{BeO}$ & $3.71_{\text {calc }}$ & 2.58 & - & $3.72_{\text {wet }}$ \\
$\mathrm{Na}_{2} \mathrm{O}$ & 14.78 & 9.18 & 10.50 & 13.32 \\
$\mathrm{~K}_{2} \mathrm{O}$ & 0.71 & 1.55 & - & 1.48 \\
$\mathrm{Cs} \mathrm{O}_{2}$ & 0.04 & - & - & 0.88 \\
$\mathrm{Rb}_{2} \mathrm{O}$ & 0.31 & - & - & 1.77 \\
$\mathrm{H}_{2} \mathrm{O}^{+}$ & - & 5.00 & 5.50 & - \\
$\mathrm{H}_{2} \mathrm{O}^{-}$ & - & 2.50 & - & - \\
$\mathrm{F}$ & 2.99 & - & 3.75 & $3.77_{\text {wet }}$ \\
$-\mathrm{O}^{-} \mathrm{F}$ & 1.26 & - & - & - \\
\hline $\mathrm{Total}$ & 99.69 & $97.99 * *$ & 100.12 & 99.39 \\
\hline
\end{tabular}

* Sample: 1-3-Karnasurt, Lovozero [61,72,92], 4-Eveslogchorr, Khibiny [47]. BeO calc from Be = 2 apfu. ** in sample 2 [92] the misleading total 99.99.

Leucophanite $\mathrm{NaCaBeSi}_{2} \mathrm{O}_{6} \mathbf{F}$ was firstly mentioned by Chernik [38] in Khibiny massif (Figure 2), but it was not properly studied. Full description and study of the mineral from the eudialyte-nepheline-aegirine-microcline vein in gneissose rischorrite at Mt Eveslogchorr, Khibiny massif, was provided by Men'shikov [31]. Leucophanite forms individual platy pale-creamy transparent crystals up to $10 \mathrm{~cm}$ in diameter and $5 \mathrm{~mm}$ wide (Figure 15a) and the color may be green because of abundant inclusions of aegirine or brown because the occurrence of astrophyllite inclusions. In the central part of vein the leucophanite crystals are among the mass of natrolite, which also contains wadeite, pectolite, rinkite, barylite, shcherbakovite, perlialite, thorite, fluorapatite, galena, löllingiteand safflorite [20].

Later, leucophanite was found as a common mineral in many hydrothermal veins, located in nepheline syenites and foidolites of Khibiny massif [47]. The mineral from pectolite-natrolite veins in ijolite-urtite and foyaite of Mts Kukisvumchorr and Yuksporr occurs in cavities of central part of vein and forms individual tabular crystals of milky-white to light-gray color up to $7 \times 8 \times 1 \mathrm{~cm}$ in size. It is associated with fluorite, strontianite, calcite and sphalerite. Leucophanite crystals become more abundant in the vein margins, but their grain size is smaller.

Leucophanite from the central part of a feldspar-natrolite vein (in the rischorrite of $\mathrm{Mt}$ Rasvumchorr) forms platy milky-white crystals up to $6 \mathrm{~cm}$ in diameter among columnar aggregates of natrolite, in association with titanite, cafetite, lorenzenite, mosandrite-(Ce), astrophyllite, priderite and shcherbakovite [20]. 


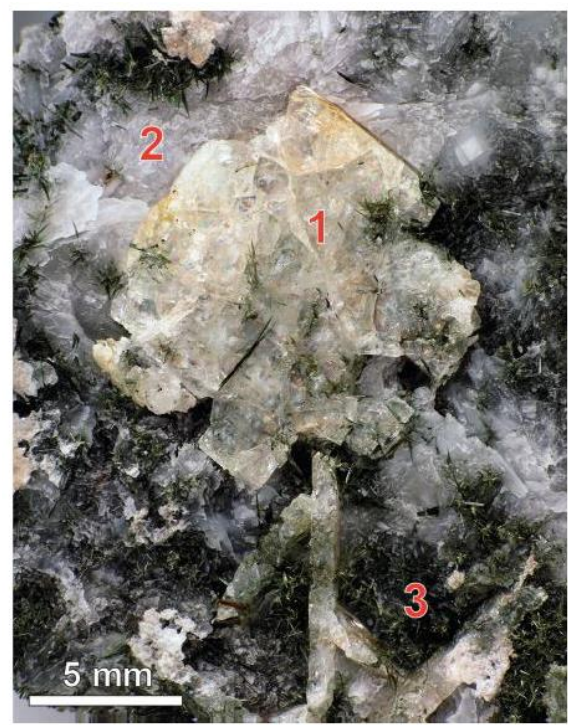

(a)

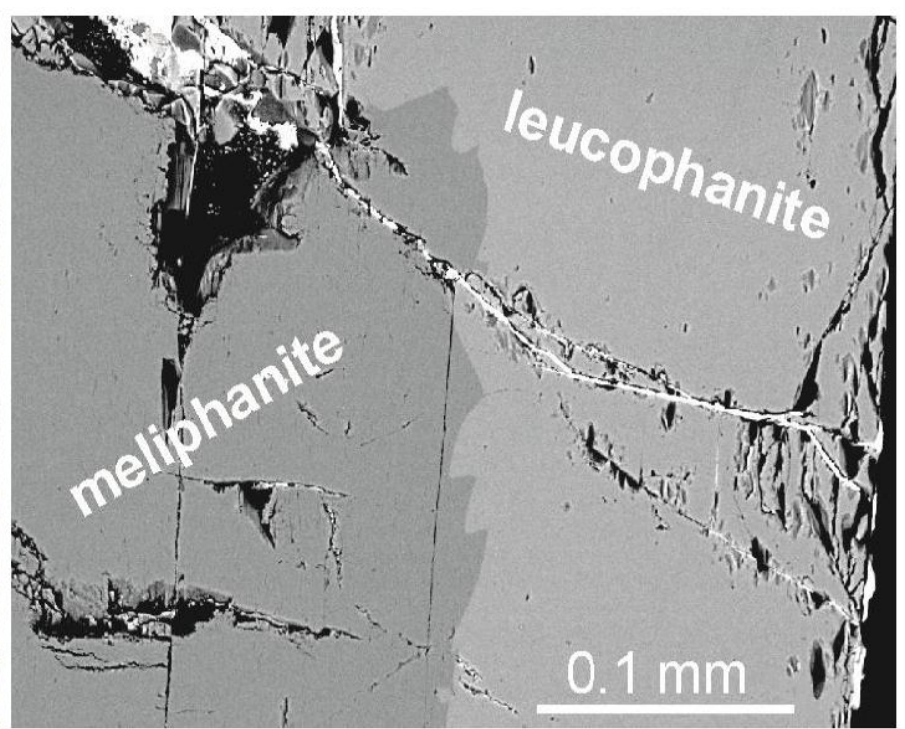

(b)

Figure 15. Leucophanite and meliphanite: (a) leucophanite crystals (1) in natrolite (2), with aegirine (3), from eudialyte-nepheline-aegirine-microcline vein in rischorrite, Mt Eveslogchorr; (b) fragment of porphyroblastic meliphanite crystal with leucophanite zone from biotite metasomatite, Sakharjok. SEM, BSE image.

Leucophanite is also found in differentiated pegmatites with agpaitic mineralization in foidolites of Mt Koashva, Khibiny massif [95]. The largest crystals are of $5 \mathrm{~cm}$ and $0.5 \mathrm{~cm}$ thickness. The mineral forms tabular semitransparent colorless and light-beige crystals among blocky villiaumite, in association with thermonatrite, aegirine, microcline, lamprophyllite, astrophyllite and lorenzenite. Crystals of loparite-(Ce) are embedded in leucophanite.

Semenov [96] described leucophanite from the natrolite core of large natrolite-feldspar pegmatite in sodalite-nepheline syenite of Mt Lepkhe-Nelm, Lovozero massif (Figure 2). Spherules up to $1 \mathrm{~cm}$ of this mineral occur in cavities and cracks in natrolite aggregate together with fluorapatite, fluorite, polylithionite, manganoneptunite and kupletskite. Pink-red UV luminescence is indicated for the mineral.

Leucophanite is established also in biotite metasomatite rimming the large nepheline-syenite pegmatite in Sakharjok massif (Figure 1), Keivy alkaline province [97]. It forms outer zones of poikilitic meliphanite crystals (Figure 15b) with uneven boundary between minerals.

Composition of leucophanite is given in Table 17.

Lovdarite $\mathrm{K}_{2} \mathrm{Na}_{6} \mathrm{Be}_{4} \mathrm{Si}_{14} \mathrm{O}_{36} \cdot \mathbf{9 H}_{2} \mathrm{O}$, a very rare late hydrothermal mineral, was found by Men'shikov [44] in "Yubileinaya" pegmatite, Mt Karnasurt, Lovozero massif (Figure 2). Lovdarite occurs as white and yellowish white rims up to $1-5 \mathrm{~cm}$ width on chkalovite crystals and sometimes is replacing them completely. Lovdarite aggregates are massive with no distinguishing features or radial. Druses of small colorless prismatic crystals of lovdarite (1-2 mm in length) are present in the cavities in the aggregates of lovdarite and chkalovite (Figure 16). Ilmajokite, leucosphenite, zorite, mountainite, natrolite, raite, serandite, chkalovite, and some other associate with lovdarite. Composition of lovdarite is given in Table 18. 
Table 17. Chemical composition of leucophanite.

\begin{tabular}{ccccc}
\hline Sample * & 1, WCA & 2, EMP & 3, WCA & 4, EMP \\
\hline Component & \multicolumn{5}{c}{ wt \% } \\
\hline $\mathrm{SiO}_{2}$ & 49.69 & 50.55 & 45.98 & 47.85 \\
$\mathrm{Al}_{2} \mathrm{O}_{3}$ & 0.55 & - & 2.32 & - \\
$\mathrm{FeO}$ & - & 0.04 & 0.22 & - \\
$\mathrm{MgO}$ & 0.10 & - & 0.30 & - \\
$\mathrm{MnO}$ & - & - & - & 0.03 \\
$\mathrm{CaO}$ & 20.90 & 22.26 & 23.65 & 22.43 \\
$\mathrm{BeO}$ & 10.77 & 10.39 calc & 11.52 & $9.96_{\text {calc }}$ \\
$\mathrm{SrO}$ & - & 0.39 & - & - \\
$\mathrm{Na}{ }_{2} \mathrm{O}$ & 13.14 & 12.40 & 10.79 & 12.58 \\
$\mathrm{~K}_{2} \mathrm{O}$ & 0.02 & 0.01 & 0.70 & - \\
$\mathrm{H}_{2} \mathrm{O}$ & 1.29 & - & 0.83 & - \\
$\mathrm{F}$ & 5.71 & 4.04 & 7.04 & 7.08 \\
$-\mathrm{O}=\mathrm{F}$ & 2.39 & 1.70 & 2.96 & 2.98 \\
\hline $\mathrm{Total}$ & 99.78 & 96.53 & 100.40 & 96.95
\end{tabular}

* Sample: 1-Eveslogchorr, Khibiny [31], 2-Koashva, Khibiny [95], 3-Lepkhe-Nelm, Lovozero [96], 4-Sakharjok [97]. $\mathrm{BeO}_{\text {calc }}$ from the atomic ratio $\mathrm{Si}: \mathrm{Be}=2: 1$.

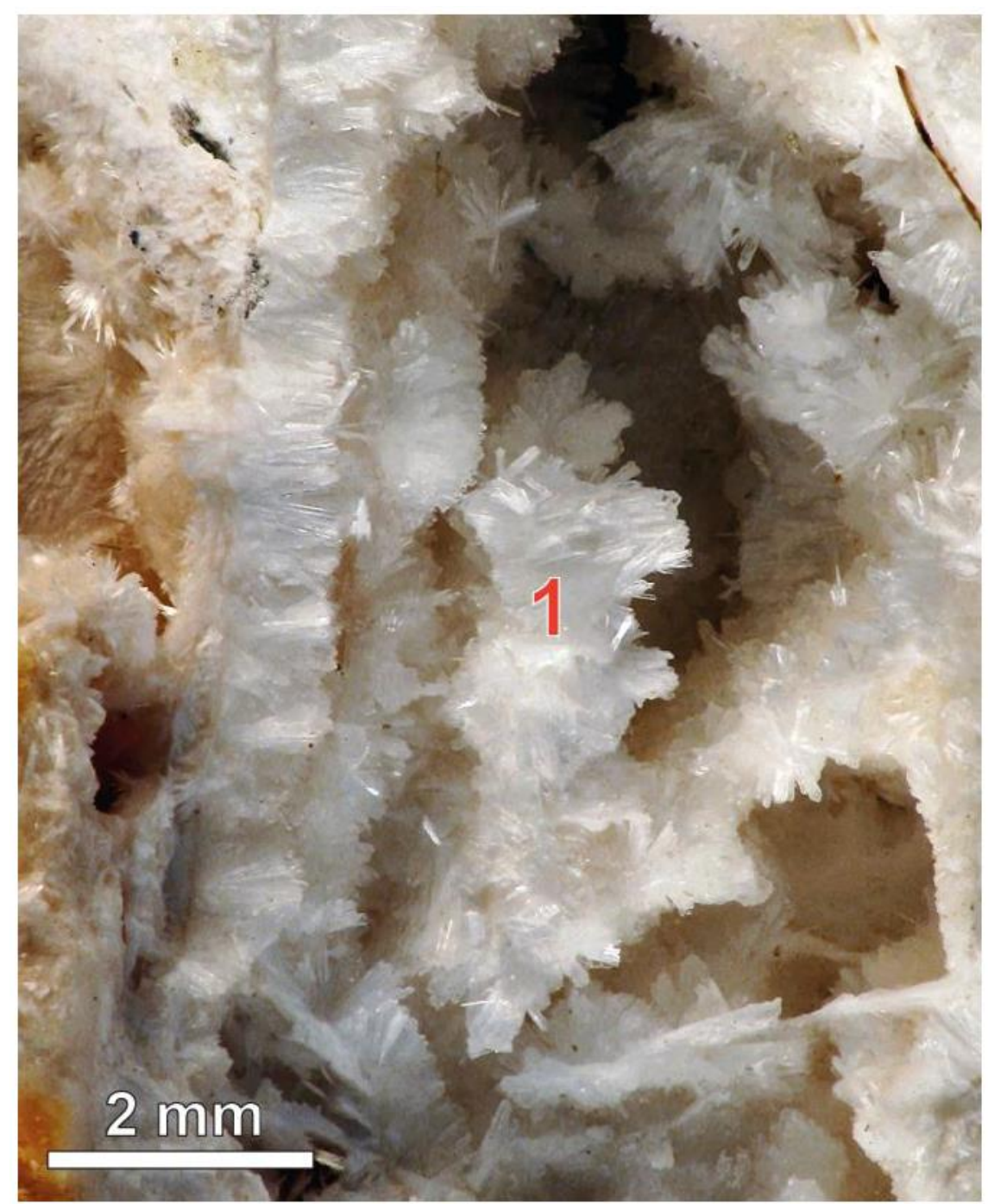

Figure 16. Lovdarite crystals (1) in porous pseudomorph after chkalovite, from the aegirinefeldspar-natrolite vein "Yubileinaya", the Karnasurt mine, Lovozero. 
Table 18. Chemical composition of lovdarite.

\begin{tabular}{cc}
\hline Sample $^{*}$ & $\mathbf{1 , W C A}$ \\
\hline Component & wt \% \\
\hline $\mathrm{P}_{2} \mathrm{O}_{5}$ & 0.05 \\
$\mathrm{SiO}_{2}$ & 56.13 \\
$\mathrm{TiO}_{2}$ & 0.15 \\
$\mathrm{Al}_{2} \mathrm{O}_{3}$ & 1.77 \\
$\mathrm{Fe}_{2} \mathrm{O}_{3}$ & 0.18 \\
$\mathrm{MgO}$ & 0.06 \\
$\mathrm{CaO}$ & 0.49 \\
$\mathrm{BaO}$ & 0.20 \\
$\mathrm{BeO}$ & 6.90 \\
$\mathrm{Na}_{2} \mathrm{O}$ & 14.95 \\
$\mathrm{~K}_{2} \mathrm{O}$ & 6.28 \\
$\mathrm{H}_{2} \mathrm{O}^{+}$ & 10.85 \\
$\mathrm{H}_{2} \mathrm{O}^{-}$ & 1.44 \\
$\mathrm{~F}$ & 0.07 \\
$-\mathrm{O}^{-} \mathrm{F}$ & 0.02 \\
\hline $\mathrm{Total}$ & 99.50 \\
\hline
\end{tabular}

* Sample: 1-Karnasurt, Lovozero [44].

Lovdarite was found also at the dumps of the Karnasurt mine [32] as radial and fibrous aggregates of acicular crystals up to $2 \mathrm{~mm}$ in length in the cavities of the selvage of an unknown large pegmatite. The study of the crystal structure [98] showed that lovdarite is some sort of berylosilicate zeolite, and allowed to write the current structural formula of this mineral.

Meliphanite $\mathrm{Ca}_{4}(\mathrm{Na}, \mathrm{Ca})_{4} \mathrm{Be}_{4} \mathrm{AlSi}_{7} \mathrm{O}_{24}(\mathrm{~F}, \mathrm{O})_{4}$ presence is reliable only in alkaline rocks of Sakharjok massif, Keivy alkaline province (Figure 1). The mineral existence in the West Keivy peralkaline granite massif (Mt Rovgora) and Khibiny massif (https://www.mindat.org) has not been confirmed by publications.

First data on meliphanite (morphology, macroscopic and optical properties, X-ray powder data and chemical composition) from Sakharjok were published in [99]. Meliphanite is widespread in the nepheline syenite pegmatite as platy or tabular crystals up to $2-3 \mathrm{~cm}$ in size and up to $0.5 \mathrm{~cm}$ in thickness (Figure 17a), also as radiating and randomly oriented aggregates [99,100]. Meliphanite from biotite metasomatite occurs as porphyroblastic crystals and grains up to $5 \mathrm{~cm}$ in size (Figure 17b). X-ray investigation of Sakharjok meliphanite by Belkov and Denisov allowed at first time determine the correct type of the unit cell of the mineral as body-centered, not primitive. Recent investigation including infrared and Raman spectroscopy, chemical and electron microprobe analyses (Table 19), thermogravimetric analysis, and the single crystal X-ray diffraction had revealed the presence of $\mathrm{OH}$-groups in meliphanite from Sakharjok and had refined the empirical formula of this mineral, particularly in its anionic part [100]. Meliphanite is the main beryllium mineral in the rocks of Sakharjok alkaline massif. A noteworthy fact is that leucophanite and meliphanite occur as intergrowths [101]. Meliphanite is "parent" for behoite crystallization. 


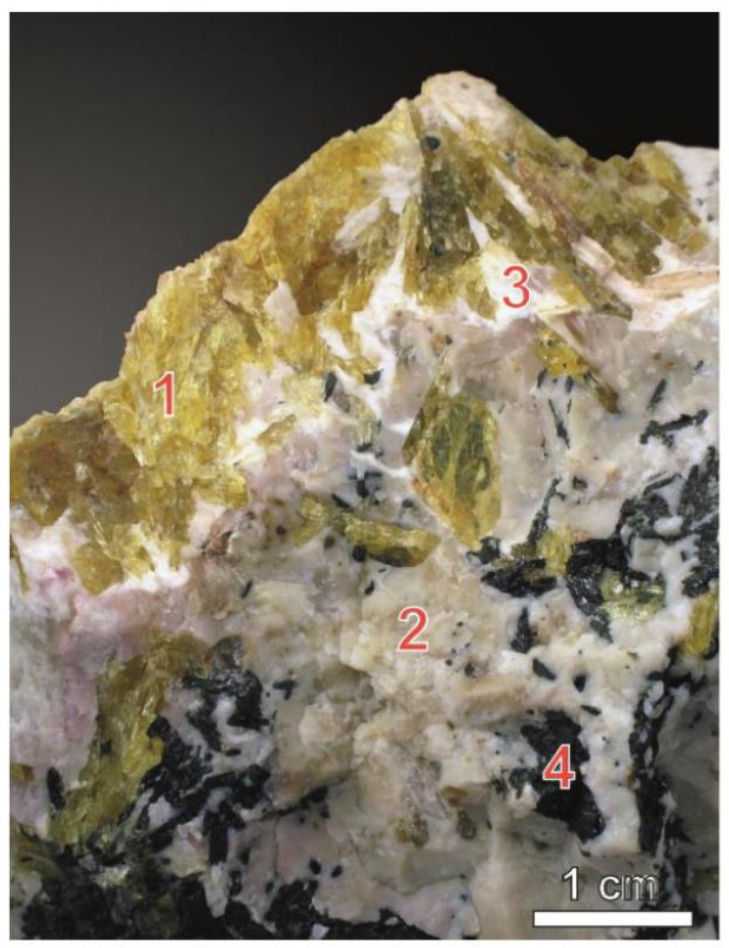

(a)

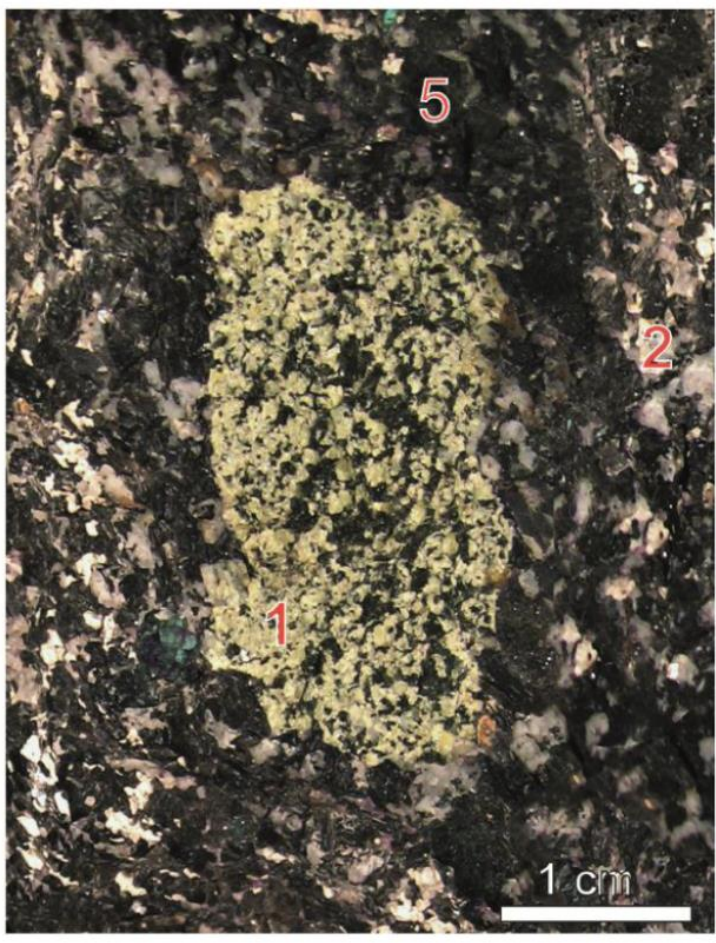

(b)

Figure 17. Meliphanite (1): (a) platy crystals with nepheline (2), natrolite (3), aegirine (4) in alkaline pegmatite, Sakharjok; (b) porphyroblastic crystals with natrolite (3) and biotite (5) in biotite metasomatite, Sakharjok.

Table 19. Chemical composition of meliphanite.

\begin{tabular}{cc}
\cline { 2 - 2 } Sample $^{*}$ & $\mathbf{1 , \text { EMP }}$ \\
\cline { 2 - 3 } Component & $\mathbf{w t} \%$ \\
\hline $\mathrm{SiO}_{2}$ & 43.30 \\
$\mathrm{Al}_{2} \mathrm{O}_{3}$ & 4.95 \\
$\mathrm{FeO}$ & 0.05 \\
$\mathrm{CaO}$ & 28.83 \\
$\mathrm{BeO}$ & $10.23_{\text {calc }}$ \\
$\mathrm{Na}_{2} \mathrm{O}$ & 8.55 \\
$\mathrm{~F}$ & 5.41 \\
$-\mathrm{O}=\mathrm{F}$ & 2.28 \\
$\mathrm{H}_{2} \mathrm{O}^{+}$ & 0.47 wet \\
$\mathrm{Total}$ & 99.51
\end{tabular}

* Sample: 1 -Sakharjok [100]. $\mathrm{BeO}_{\text {calc }}$ from the atomic ratio $(\mathrm{Si}+\mathrm{Al}): \mathrm{Be}=2: 1$.

Milarite $\mathrm{KCa}_{2}\left(\mathrm{Be}_{2} \mathrm{AlSi}_{12}\right) \mathrm{O}_{30} \cdot \mathrm{H}_{2} \mathrm{O}$ was found in a quartz-albite-microcline pegmatite in the Kolmozero-Voronja belt [102,103]. Milarite together with bavenite and chabazite grow in cavities and fractures on the microcline and albite crystals. Co-crystallization of these minerals indicate that milarite is a late low-temperature hydrothermal mineral. Milarite from its type locality [104] and the Kolmozero-Voronja (Table 20) differ by Be:Al apfu ratio-2:1 and 1:1, respectively. The substitution of $\mathrm{Be}^{2+}$ by $\mathrm{Al}^{3+}$ needs charge balance, for example through the replacement of $\mathrm{O}^{2-}$ anions by $\mathrm{OH}^{-}$-groups [103]. 
Table 20. Chemical composition of milarite.

\begin{tabular}{cc}
\hline Sample $^{*}$ & $\mathbf{1 , \text { WCA }}$ \\
\hline Component & wt \% \\
\hline $\mathrm{SiO}_{2}$ & 71.12 \\
$\mathrm{Al}_{2} \mathrm{O}_{3}$ & 7.70 \\
$\mathrm{CaO}$ & 11.55 \\
$\mathrm{BeO}$ & 3.57 \\
$\mathrm{~K}_{2} \mathrm{O}$ & 4.80 \\
$\mathrm{Na}_{2} \mathrm{O}$ & 0.30 \\
$\mathrm{H}_{2} \mathrm{O}^{-}$ & 0.14 \\
$\mathrm{H}_{2} \mathrm{O}^{+}$ & 1.25 \\
\hline $\mathrm{Total}^{+}$ & 100.43 \\
\hline * Sample: 1-Kolmozero-Voronja [103].
\end{tabular}

Moraesite $\mathrm{Be}_{2}\left(\mathrm{PO}_{4}\right)(\mathrm{OH}) \cdot 4 \mathbf{H}_{2} \mathrm{O}$ is the only beryllium phosphate which was found by Pekov [105] in the "Natrolite Stock" pegmatite at Mt Karnasurt, Lovozero massif (Figure 2). Moraesite forms spherical or hemispherical aggregates up to $1 \mathrm{~mm}$ in diameter made of radiating acicular crystals up to $0.05 \mathrm{~mm}$ in size. Moraesite aggregates grow on the tabular complex twins of epididymite or in cavities in it (Figure 18). Mineral association of moraesite with bertrandite is noted. Other beryllium minerals as leifite and beryllite are also present in this pegmatite. The mineral was detected by XRD and FTIR, and the presence of beryllium is confirmed by spectral analysis.

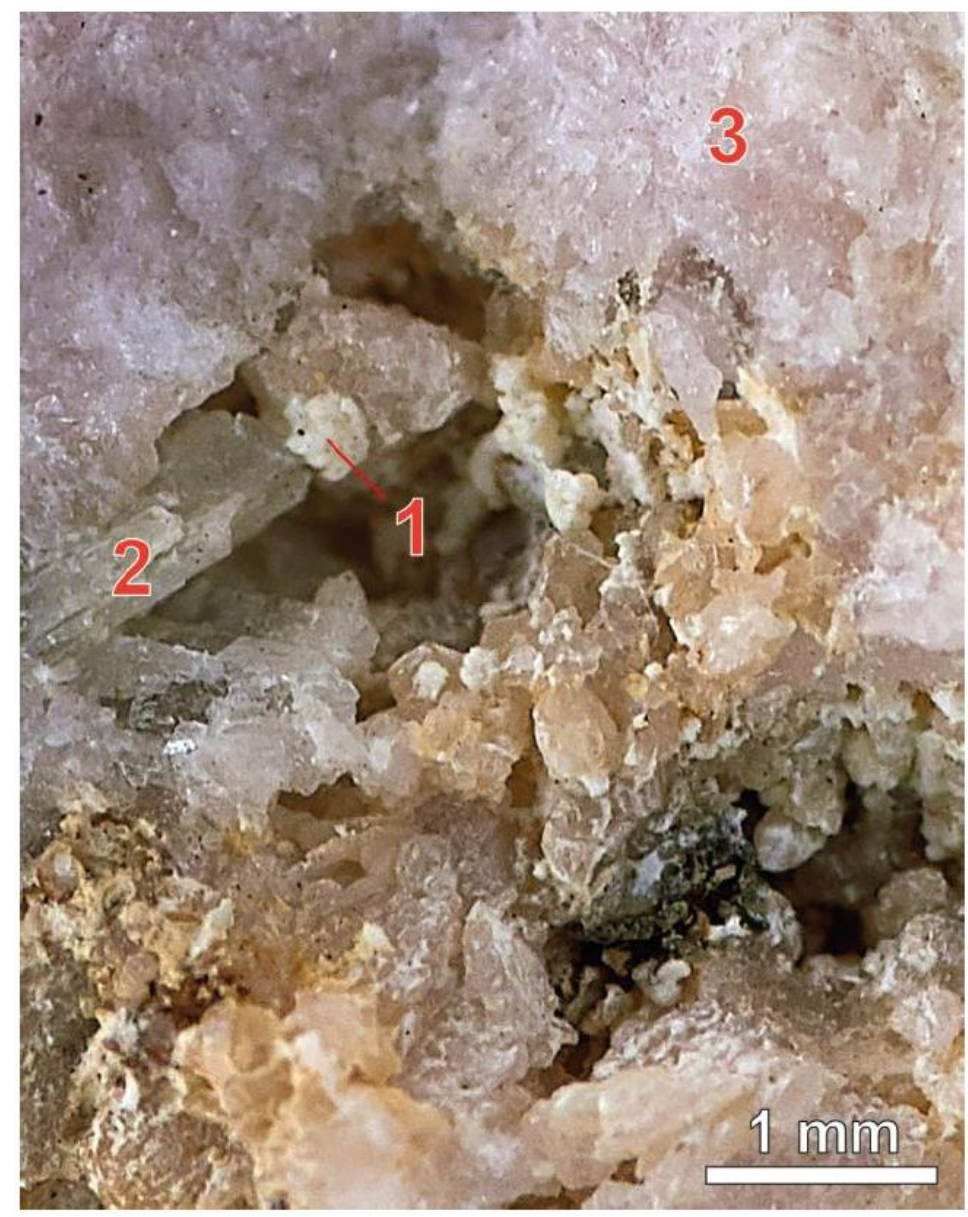

Figure 18. Moraesite aggregates (1) growing on epididymite (2) and albite (3), from the "Natrolite Stock" pegmatite, Mt Karnasurt, Lovozero. 
Odintsovite $\mathrm{K}_{2} \mathrm{Na}_{4} \mathrm{Ca}_{3} \mathrm{Ti}_{2} \mathrm{Be}_{4} \mathrm{Si}_{12} \mathrm{O}_{38}$ was found in the pegmatite vein in a drilling core at Mt Koashva, Khibiny massif (Figure 2). Detailed investigation of this mineral was carried out by Khomyakov and Pekov [95]. Odintsovite has grayish-pink color and occurs as granular aggregates up to $4 \mathrm{~cm}$ in size in which it is associated with $\mathrm{K}$-feldspar, sodalite, aegirine, fluorapatite and lamprophyllite. This is the third odintsovite location in the world after Murun alkaline massif in East Siberia (type locality) [106] and Ilimaussaq massif, South West Greenland [107]. The mineral from Khibiny (Table 21) is similar to odintsovite from Murun massif in composition, X-ray and IR-spectroscopy data, but different by blue-white color fluorescence in short-wave UV light.

Table 21. Chemical composition of odintsovite.

\begin{tabular}{cc}
\hline Sample $^{*}$ & 1, EMP \\
\hline Component & wt \% \\
\hline $\mathrm{SiO}_{2}$ & 52.49 \\
$\mathrm{TiO}_{2}$ & 11.51 \\
$\mathrm{Fe}_{2} \mathrm{O}_{3}$ & 0.48 \\
$\mathrm{CaO}$ & 11.91 \\
$\mathrm{BeO}$ & $7.28_{\text {calc }}$ \\
$\mathrm{Na}{ }_{2} \mathrm{O}$ & 8.35 \\
$\mathrm{~K}_{2} \mathrm{O}$ & 7.36 \\
\hline $\mathrm{Total}$ & 99.38 \\
\hline
\end{tabular}

* Sample: 1-Koashva, Khibiny [95].

Sphaerobertrandite $\mathrm{Be}_{3}\left(\mathrm{SiO}_{4}\right)(\mathrm{OH})_{2}$. This mineral has a long intricate history. Sphaerobertrandite was first described as a new mineral by Semenov [108], who found the mineral in a few pegmatites at Mts Mannepakhk, Kuftnyun, and Sengischorr in Lovozero massif (Figure 2). In all these pegmatites, sphaerobertrandite occurs as spherulites in cavities of epididymite druses (Figure 19). The formula $\mathrm{Be}_{5} \mathrm{Si}_{2} \mathrm{O}_{7}(\mathrm{OH})_{4}$ was proposed for sphaerobertrandite. The absence of single crystal X-ray data and/or structural analogies with known phases did not allow the determination of the symmetry or the unit cell dimensions of sphaerobertrandite. Sphaerobertrandite was therefore not included in the system of valid mineral species by the time of foundation of the Commission on New Minerals and Mineral Names of the IMA in 1959. On the other hand, the mineral has never been formally discredited. Later Semenov [61] described one more occurrence of sphaerobertrandite at Mt Lepkhe-Nelm, and gave new chemical analysis of sphaerobertrandite from Mt Kuftnyun. The unique crystal structure of sphaerobertrandite was studied on a crystal from Mt Sengischorr (Table 22), Lovozero massif only in 2003 [57] and an ideal structural formula, $\mathrm{Be}_{3} \mathrm{SiO}_{4}(\mathrm{OH})_{2}$, was suggested for sphaerobertrandite based on structural data. The mineral is now confirmed and takes its valid place in the mineralogical nomenclature.

"Gelbertrandite" was described simultaneously with sphaerobertrandite [108]. Upon further decrease of the temperature, "gelbertrandite", $\mathrm{Be}_{4} \mathrm{Si}_{2} \mathrm{O}_{7}(\mathrm{OH})_{2} \cdot \mathrm{nH}_{2} \mathrm{O}($ ?) appears in these pegmatites. The latter mineral is an insufficiently described phase, which has an X-ray powder pattern very similar to bertrandite but with broad and weak lines [108]. It is probably a poorly crystalline, hydrated variety of bertrandite.

Sphaerobertrandite was noted also at Mt Yuksporr, Khibiny massif, but without further description [108]. 


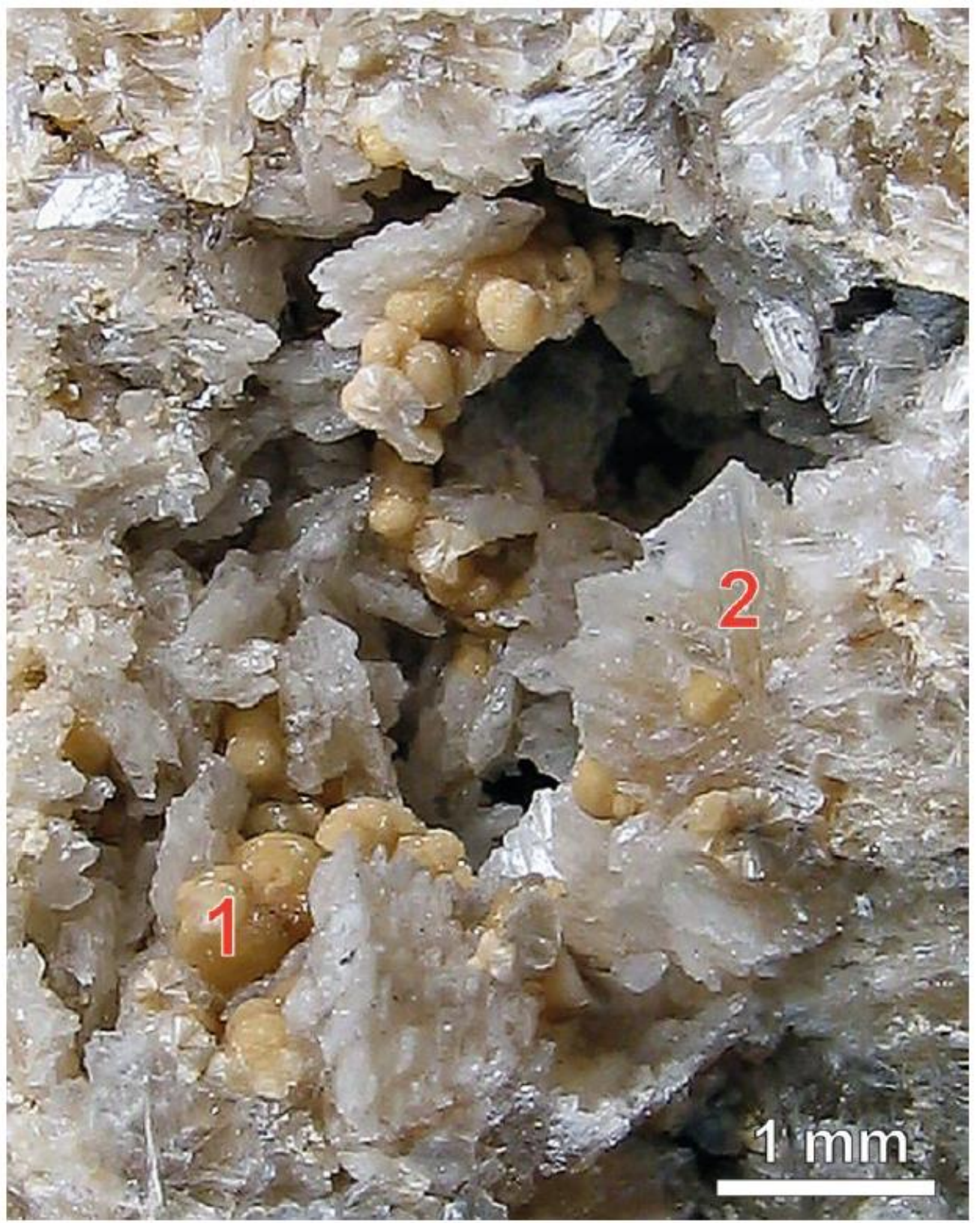

Figure 19. Sphaerobertrandite spherulites (1) on/in epididymite trillings (2), from an aegirine-feldspar vein in sodalite-nepheline syenite, Mt Sengischorr, Lovozero.

Table 22. Chemical composition of sphaerobertrandite.

\begin{tabular}{ccc}
\hline Sample $^{*}$ & 1, WCA & 2, EMP \\
\hline Component & \multicolumn{3}{c}{ wt \% } \\
\hline $\mathrm{Al}_{2} \mathrm{O}_{3}$ & 1.40 & - \\
$\mathrm{Fe}_{2} \mathrm{O}_{3}$ & 0.07 & - \\
$\mathrm{SiO}_{2}$ & 41.03 & 38.46 \\
$\mathrm{BeO}$ & 45.20 & $45.88_{\text {wet }}$ \\
$\mathrm{H}_{2} \mathrm{O}^{+}$ & 12.00 & 12.54 \\
\hline Total & 99.70 & 96.88
\end{tabular}

* Sample: 1-Mannepakhk, Lovozero [108], 2-Sengischorr, Lovozero [57]. 
Tugtupite $\mathrm{Na}_{4} \mathrm{AlBeSi}_{4} \mathrm{O}_{12} \mathrm{Cl}$ is found in pegmatite veins of Mts Sengischorr and Punkaruaiv, Lovozero massif (Figure 2). Previously the mineral was considered as a new mineral species and published as "beryllosodalite" [43]. The mineral forms rounded and irregular grains up to $0.3 \mathrm{~cm}$ colored in blue or pale green, but it tends to be pink. "Beryllosodalite" occurs as a hydrothermal alteration product of chkalovite. Simultaneously with Semenov and Bykova [43] other authors [109] described unnamed beryllium mineral in a pegmatite from the nepheline syenite of Ilimaussaq, South West Greenland. According to Fleischer [110] both papers describe the same mineral. Two years later, analysis of mineral from Ilimaussaq was published and it is very close to that of beryllosodalite of Semenov and Bykova [111]. Nevertheless, the priority of type locality and the name of the mineral are assigned to the mineral from Ilimaussaq, Greenland.

Later the mineral was found in the ussingite zone of the pegmatite body "Shkatulka" at Mt Alluaiv, Lovozero massif. Different morphological types were discovered here: (a) 3-5 mm thick crimson-colored borders around large aggregates of chkalovite; (b) pink round aggregates among ussingite and small spherules in the cavities [47]. Transparent tugtupite with shades of green and blue grows into eudialyte, along with ussingite, terskite, manganoneptunite, lomonosovite, bornemanite, etc. in the pegmatite vein "Sirenevaya" at Mt Alluaiv. In natrolitized proto-ussingite pegmatite "Shkatulka", there are complete pseudomorphs of tugtupite after well-shaped chkalovite crystals (Figure 20a).

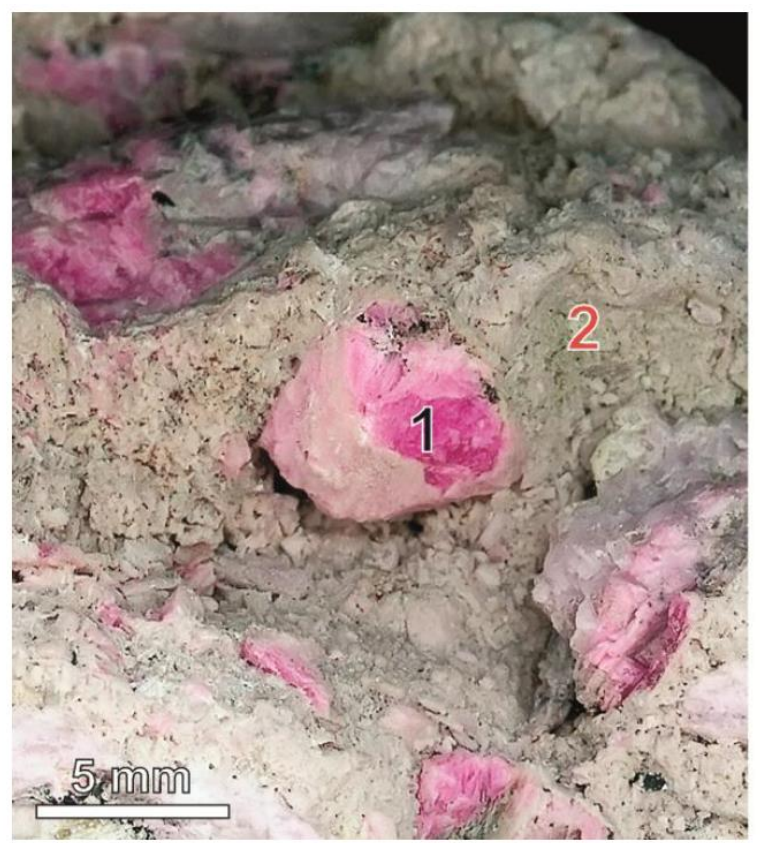

(a)

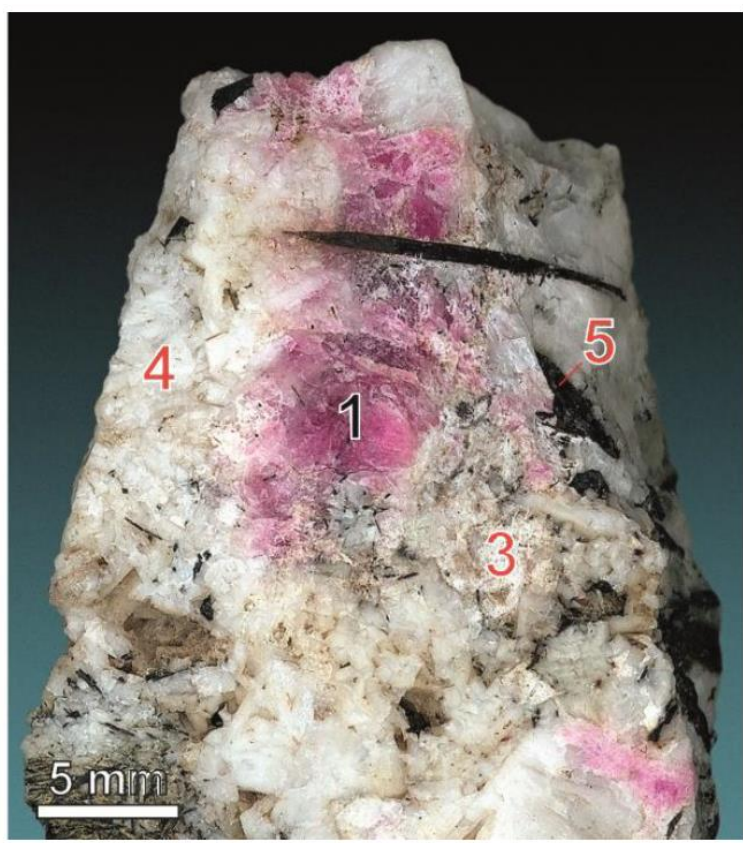

(b)

Figure 20. Tugtupite (1): (a) pseudomorphs after chkalovite, on natrolite (2), from the aegirine-feldspar-natrolite vein "Yubileinaya", Lovozero; (b) irregularly shaped segregation partially replaced by epididymite (3) in microcline (4), with aegirine (5), from a microcline-natrolite vein in foyaite, Mt Eveslogchorr, Khibiny.

A peculiarity of tugtupite from the Lovozero massif is its high content of gallium (up to $0.04 \mathrm{wt} \%$ $\mathrm{Ga}_{2} \mathrm{O}_{3}[43]$ ) (Table 23). 
Table 23. Chemical composition of tugtupite.

\begin{tabular}{ccc}
\hline Sample $^{*}$ & 1, WCA & 2, EMP \\
\hline Component & \multicolumn{3}{c}{ wt \% } \\
\hline $\mathrm{SiO}_{2}$ & 50.45 & 51.86 \\
$\mathrm{Al}_{2} \mathrm{O}_{3}$ & 12.56 & 10.31 \\
$\mathrm{Ga}_{2} \mathrm{O}_{3}$ & 0.04 & - \\
$\mathrm{CaO}$ & 0.50 & - \\
$\mathrm{BeO}$ & 5.30 & $5.36_{\text {wet }}$ \\
$\mathrm{Na}_{2} \mathrm{O}$ & 23.26 & 25.22 \\
$\mathrm{~K}_{2} \mathrm{O}$ & 0.40 & 0.09 \\
$\mathrm{H}_{2} \mathrm{O}^{+}$ & 1.50 & - \\
$\mathrm{H}_{2} \mathrm{O}^{-}$ & 1.51 & - \\
$\mathrm{Cl}$ & 6.04 & 7.07 \\
$-\mathrm{O}=\mathrm{Cl}$ & 1.40 & - \\
\hline Total & 100.26 & 99.91 \\
\hline * Sample: 1 -Sengischorr, Lovozero [43], 2-Eveslogchorr, Khibiny [47].
\end{tabular}

Tugtupite is found and described in a natrolite-feldspar vein intruding nepheline syenite at $\mathrm{Mt}$ Eveslogchorr, Khibiny massif [20,31]. Crimson-colored anhedral crystals of tugtupite up to $1 \mathrm{~cm}$ in size are located in feldspar aggregate and associated with lamprophyllite, manganoneptunite, murmanite, belovite-(La), and safflorite. Tugtupite grains are usually partially replaced by epididymite (Figure 20b).

\section{Discussion}

The distribution of beryllium mineralization on the Kola Peninsula serves a confirmation of chemical and crystal chemical patterns in beryllium behavior [4,6,8,17]: (a) beryllium species are more diverse in younger rocks in comparison with ancient ones; (b) beryllium tends to be accumulated in the differentiated products of alkaline magmatism, saturated or undersaturated; (c) alteration of primary Be minerals may produce complex secondary paragenesis during hydrothermal or weathering stages.

Beryllium is present in ore mainly in the form of its own minerals, and, less frequently, in the form of isomorphic impurity in rock-forming minerals. Thus, about $98 \%$ of beryllium from Kolmozerskoe deposit is concentrated in beryl and about $1 \%$ is incorporated in mica as isomorphic impurity [51].

It can be seen from the Table 1 that in the Kola Peninsula some minerals were formed in different environments. For example, epididymite occurs in different rocks of alkaline and alkaline- ultramafic complexes, gadolinite- $(\mathrm{Y})$ is connected to different late products of peralkaline granite magmatism, leucophanite, genthelvite and gadolinite-(Ce) are connected with both alkaline and peralkaline granite complexes.

Beryllium mineralization of the Khibiny massif is associated with two different types of alkaline pegmatites: (1) in nepheline syenite; (2) in xenoliths of fenitized basic volcanites in foyaite. Geological environment of beryllium minerals in Lovozero massif is more diverse: (1) pegmatites within alkaline rocks, (2) albitites; (3) contact fenites, (4) feldspar pegmatites in xenoliths of host trapps and gneisses. However, the vast majority of beryllium minerals are related to alkaline pegmatites and related hydrothermalites. In the Keivy alkaline province Be-minerals are present in different late- and postmagmatic products of peralkaline granite magmatism and also in metasomatically altered host rocks associated with the intrusion of peralkaline granites. Beryllium minerals of Kolmozero-Voronja belt are identified only in rare-metal pegmatites.

Kolmozerskoe deposit of $\mathrm{Li}, \mathrm{Be}, \mathrm{Nb}$ and $\mathrm{Ta}$ contain beryl as quite common ore mineral of spodumene LCT-type pegmatites like worldwide (e.g., Greenbushes, Wodgina and Mt Cattlin in Australia, Bernic Lake, La Corne and Wekusko in Canada, and North Carolina in USA [25]).

Like a beryl, the Kola meliphanite, leucophanite, chkalovite and epididymite are also found in different types of alkaline rocks in significant amounts. 
Meliphanite and leucophanite have very similar crystal structures and both of them are postmagmatic primary minerals, although their associated locations are different, particularly in alkalinity: more structural-ordered and high-calcium meliphanite is associated with alkaline metasomatically altered rock of Sakharjok massif and less ordered leucophanite is associated with alkaline pegmatites of Khibiny and Lovozero. It was considered impossible for them to coexist [101] but unique overgrowths have been discovered [100].

Chkalovite is a characteristic hyper-alkaline mineral which forms closed intergrowths with villiaumite and occurs in the border or core zones of pegmatites in the Khibiny and Lovozero massifs. Large aggregates and grains of chkalovite remain unaltered in relatively "dry" ussingite pegmatites. However, chkalovite fully or partially alters into epididimite, tugtupite or sometimes later minerals in those pegmatites showing a distinctive hydrothermal process.

During the development of pegmatite-hydrothermal process in high-alkaline environment, a change of parageneses is being controlled by the downward trend of a mineral framework density [71]. For example, lovdarite with the highest alkali content and porous zeolite-like crystal structure has been crystallized in ultraagpaitic environment in the late hydrothermal stage of the "Yubileinaya" pegmatite formation.

Gradual decreasing alkalinity during the pegmatite formation leads to densification of framework and polymerization of beryllium tetrahedrons in the crystal structures of sequently crystallizing minerals. On this reason, leifite $\left(\mathrm{Na}_{2} \mathrm{O}\right.$ content of about $\left.13 \mathrm{wt} \%\right)$ or epididymite $\left(\mathrm{Na}_{2} \mathrm{O}\right.$ content of about $12 \mathrm{wt} \%)$ were crystallized after chkalovite $\left(\mathrm{Na}_{2} \mathrm{O}\right.$ content of about 29-30 wt \%). A sharp decline in alkalinity at the late stage of the hydrothermal process leads to polymerization of beryllium tetrahedrons and Be shifting to the cationic part of a crystal structure. As a result such minerals as sphaerobertrandite, beryllite and moraesite have been formed in many Lovozero pegmatites (i.e., in "Natrolite Stock" pegmatite).

In case of peralkaline granite pegmatite in the Keivy province, calcium, yttrium and lanthanides, become to be involved in beryllium mineral formation. So, gadolinite subgroup minerals are common in peralkaline granite pegmatites, amazonite pegmatites and peralkaline granite veins, especially in exocontact zones of the granite massifs. Conversely, in the Khibiny massif, the minerals of gadolinite subgroup can only be found in pegmatites that cut the mafic rock xenoliths, which is similar in broad sense to crystallization environment of Keivy granites. For the similar reason, chrysoberyl can be found in contact zones of high-Al hornfels with host alkaline rocks.

The unique properties of a number of Be minerals have the potential use in material science. For example, intensive fluorescence and piezoelectric effect in meliphanite allow using it in different fields of ferroelectrics. Leifite and eirikite crystal structures are able to trap the significant amount of large alkali cations, cesium and rubidium. Lovdarite is a unique berylosilicate with zeolite structure.

Author Contributions: Conceptualization, L.M.L.; Writing-Original Draft Preparation, L.M.L., E.A.S., D.R.Z.; Writing-Review \& Editing, L.M.L., E.A.S.; Visualization, L.M.L., G.Y.I.

Funding: This research was funded by the Russian Foundation for Basic Research (grant No. 16-05-00427) and Russian Government (grants Nos. 0226-2019-0051, 0226-2019-0053).

Acknowledgments: We are grateful to A. Chernyavsky, P. Goryainov, N. Frishman, N. Zhikhareva and V. Yakovenchuk for permission to use photos of minerals from their collections.

Conflicts of Interest: The authors declare no conflict of interest.

\section{References}

1. Vauquelin, N.-L. De l'aigue marine, ou béril; et découverte d'une terre nouvelle dans cette pierre. Ann. Chim. Phys. 1798, 26, 155-177, (For a Partial Translation, see Anonymous 1930).

2. Anonymous. Discovering the sweet element "A classic of science". Sci. News Lett. 1930, 18, 346-347. (A Translation of the Essential Parts of Vauquelin 1798).

3. Kogan, B.I.; Kapustinskaya, K.A.; Topunova, G.A. Berillium; Nauka: Moscow, Russia, 1975; p. 371. (In Russian) 
4. Grew, E.S. Mineralogy, Petrology and Geochemistry of Beryllium: An Introduction and List of Beryllium Minerals. Rev. Mineral. Geochem. 2002, 50, 1-76. [CrossRef]

5. Pekov, I.V. Remarkable finds of minerals of beryllium: From the Kola Peninsula to Primorie. World Stones 1994, 4, 10-26.

6. Pekov, I.V. Genetic crystal chemistry of beryllium in derivates of alkaline complexes. In Proceedings of XXI Workshop "Earth Alkaline Magmatism"; Arzamastsev, A.A., Ed.; KSC RAS: Apatity, Russia, 2003; pp. 122-123. (In Russian)

7. Aurisicchio, C.; Fioravanti, G.; Grubessi, O.; Zanazzi, P.F. Reappraisal of the crystal chemistry of beryl. Am. Mineral. 1988, 73, 826-837.

8. Beus, A.A. Geochemistry of Beryllium and Genetic Types of Beryllium Deposits; Freeman: San Francisco, CA, USA, 1966; p. 401.

9. Burt, D.M. Minerals of Beryllium. In Granitic Pegmatites in Science and Industry; Černý, P., Ed.; Short Course Handbook 8; Mineralogical Association of Canada: Québec, QC, Canada, 1982; pp. 135-148.

10. Everest, D.A. 9. Beryllium. In Comprehensive Inorganic Chemistry; Bailar, J.C., Emeléus, H.J., Nyholm, R., Trotman-Dickenson, A.F., Eds.; Pergamon: Oxford, UK; New York, NY, USA, 1973; Volume 1, pp. 531-590.

11. Gaines, R.V. Beryl-A review. Mineral. Rec. 1976, 7, 211-223.

12. Ginzburg, A.I. The Genetic Types of Hydrothermal Beryllium Deposits; Nedra: Moscow, Russia, 1975 ; p. 247. (In Russian)

13. Ginzburg, A.I.; Kupriyanova, I.I.; Novikova, M.I.; Shazkaya, V.T.; Shpanov, E.P.; Zabolotnaya, N.P.; Vasilkova, N.N.; Zhurkova, Z.A.; Zubkov, L.B.; Leviush, I.T.; et al. The Mineralogy of Hydrothermal Beryllium Deposits; Ginzburg, A.I., Ed.; Nedra: Moscow, Russia, 1976; p. 199. (In Russian)

14. Griffith, R.F. Historical Note on Sources and Uses of Beryllium. In The Metal Beryllium; White, D.W., Jr., Burke, J.E., Eds.; The American Society for Metals: Cleveland, OH, USA, 1955; pp. 5-13.

15. Hörmann, P.K. Beryllium. In Handbook of Geochemistry II/1 Elements H (1)-Al (13); Wedepohl, K.H., Ed.; Springer: Berlin, Germnay, 1978; pp. 1-6, ISBN 3540065784.

16. Kupriyanova, I.I.; Shpanov, Y.P.; Novikova, M.I.; Zhurkova, Z.A. Beryllium of Russia: Situation, Problems of Exploration and of Industrial Development of a Raw-Materials Base; Komitet Rossiyskoy Federatsii po Geologii i Ispol'zovaniyu Nedr, Geologiya, Metody Poiskov, Razvedki i Otsenki Mestorozhdeniy Tverdykh Poleznykh Iskopayemykh; Obzor, AOZT “Geoinformmark”: Moscow, Russia, 1996; p. 40. (In Russian)

17. Grew, E.S.; Hazen, R.M. Beryllium mineral evolution. Am. Miner. 2014, 99, 999-1021. [CrossRef]

18. Ross, M. Crystal Chemistry of Beryllium; US Geol Survey Prof Paper 468; U.S. Geological Survey: Washington, DC, USA, 1964; p. 30.

19. Meisser, N.; Widmer, R.; Armbruster, T.; May, E.; Bussy, F.; Ulianov, A.; Michellod, P.M. Verbierite, IMA 2015-089. CNMNC Newsletter No. 30. Mineral. Mag. 2016, 80, 408.

20. Yakovenchuk, V.N.; Ivanyuk, G.Y.; Pakhomovsky, Y.A.; Men'shikov, Y.P. Khibiny; Laplandia Minerals: Apatity, Russia, 2005; p. 468.

21. Zozulya, D.R.; Bayanova, T.B.; Eby, G.N. Geology and Age of the Late Archean Keivy Alkaline Province, Northeastern Baltic Shield. Geology 2005, 113, 601-608. [CrossRef]

22. Kalashnikov, A.O.; Konopleva, N.G.; Pakhomovsky, Y.A.; Ivanyuk, G.Y. Rare Earth Deposits of the Murmansk Region, Russia-A Review. Econ. Geol. 2016, 111, 1529-1559. [CrossRef]

23. Černý, P.; Ercit, T.S. The classification of granitic pegmatites revisited. Can. Mineral. 2005, 43, $2005-2026$. [CrossRef]

24. Afanas'ev, B.V.; Bichuk, N.I.; Dain, A.D.; Zhabin, S.V.; Kamenev, E.A. Minerals and raw material base of Murmansk region. Miner. Resour. Russia 1997, 4, 12-17. (In Russian)

25. Mohr, S.H.; Mudd, G.M.; Giurco, D. Lithium Resources and Production: Critical Assessment and Global Projections. Minerals 2012, 2, 65-84. [CrossRef]

26. Batieva, I.D.; Belkov, I.V. Sakharjokskii Peralkaline Massif, Component Rocks and Minerals; Kol'skii Filial Akademii Nauk SSSR: Apatity, Russia, 1984; p. 133. (In Russian)

27. Zozulya, D.R.; Lyalina, L.M.; Eby, N.; Savchenko, Ye.E. Ore Geochemistry, Zircon Mineralogy and Genesis of the Sakharjok Y-Zr Deposit, Kola Peninsula, Russia. Geol. Ore Dépos. 2012, 54, 81-98. [CrossRef]

28. Baginski, B.; Zozulya, D.; Macdonald, R.; Kartashov, P.; Dzierzanowski, P. Low-temperature hydrothermal alteration of a rare-metal rich quartz-epidote metasomatite from the El'ozero deposit, Kola Peninsula, Russia. Eur. J. Mineral. 2016, 28, 789-810. [CrossRef] 
29. Batieva, I.D. Alkaline Granite of Kanozero-Kolvitskoe Ozero District. In Alkaline Granite of Kola Peninsula; Izdatel'stvo akademii Nauk SSSR: Moscow, Russia, 1958; pp. 146-179. (In Russian)

30. Ivanyuk, G.; Yakovenchuk, V.; Pakhomovsky, Y.; Kalashnikov, A.; Mikhailova, J.; Goryainov, P. Self-Organization of the Khibiny Alkaline Massif (Kola Peninsula, Russia). In Earth Sciences; Dar, I.A., Ed.; InTech: Rijeka, Croatia, 2012; pp. 131-156.

31. Kostyleva-Labuntzova, E.E.; Borutzkii, B.E.; Sokolova, M.N.; Shlyukova, Z.V.; Dorfman, M.D; Dudkin, O.B.; Kosyreva, L.V. Mineralogy of Khibiny Massif (Minerals) V. 2; Nauka: Moscow, Russia, 1978; p. 586. (In Russian)

32. Pekov, I.V. Lovozero Massif: History, Pegmatites, Minerals; Ocean Press: Moscow, Russia, 2001; ISBN 978-5900395272.

33. Ivanyuk, G.Y.; Yakovenchuk, V.N.; Pakhomovsky, Y.A. Kovdor; Laplandia Minerals: Apatity, Russia, 2002; p. 326, ISBN 5900395413.

34. Kukharenko, A.A.; Orlova, M.P.; Bulakh, A.G.; Bagdasarov, E.A.; Rimskaya-Korsakova, O.M.; Nefedov, E.I.; Ilyinsky, G.A.; Sergeev, A.S.; Abakumova, N.B. Caledonian Complex of Ultrabasic, Alkaline Rocks and Carbonatites of the Kola Peninsula and Northern Karelia; Nedra: Moscow, Russia, 1965; p. 772. (In Russian)

35. Mikhailova, J.A.; Kalashnikov, A.O.; Sokharev, V.A.; Pakhomovsky, Y.A.; Konopleva, N.G.; Yakovenchuk, V.N.; Bazai, A.V.; Goryainov, P.M.; Ivanyuk, G.Y. 3D mineralogical mapping of the Kovdor phoscorite-carbonatite complex (Russia). Miner. Depos. 2016, 51, 131-149. [CrossRef]

36. Pozhilenko, V.I.; Gavrilenko, B.V.; Zhirov, D.V.; Zhabin, S.V. Geology of Mineral Areas of the Murmansk Region; Kola Science Centre RAS: Apatity, Russia, 2002; p. 359. (In Russian)

37. Aver'yanova, I.M. On the Mineralogical Processes of Beryl Change. In Materialy po Mineralogii Kolskogo Poluostrova. Vyp.2; Kola Branch of USSR Academy of Sciences: Apatity, Russia, 1962; pp. 140-142. (In Russian)

38. Chernik, G.P. Results of the analysis of some minerals of the Khibiny laccolite, Kola Peninsula. Gornyi Zhurnal 1927, 12, 740-753. (In Russian)

39. Kostyleva, E.E. Catapleiite from the Khibiny tundra. Izvestiya Akademii Nauk SSSR 1932, 8, 1109-1125. (In Russian)

40. Kostyleva, E.E. Leucophan, Melinophan. In Minerals of Khibiny and Lovozero Tundras; Izdatel'stvo Akademii Nauk SSSR: Moscow, Russia, 1937; p. 243. (In Russian)

41. Gerasimovsky, V.I. Chkalovite. Dokl. Akad. Nauk SSSR 1939, 22, 263-267. (In Russian)

42. Kuzmenko, M.V. Beryllite-new mineral. Dokl. Akad. Nauk SSSR 1954, 99, 3-451. (In Russian)

43. Semenov, E.I.; Bykova, A.V. Beryllosodalite. Dokl. Akad. Nauk SSSR 1960, 133, 64-66. (In Russian)

44. Men'shikov, Yu.P.; Denisov, A.P.; Uspenskaya, E.I.; Lipatova, E.A. Lovdarite-new hydrous beryllosilicate of alkalis. Dokl. Akad. Nauk SSSR 1973, 213, 429-432. (In Russian)

45. Voloshin, A.V.; Pakhomovsky, Ya.A.; Men'shikov, Yu.P.; Povarennykh, A.S.; Matvienko, E.N.; Yakubovich, O.V. Hingganite-(Yb), a new mineral in amazonitic pegmatites of the Kola Peninsula. Dokl. Akad. Nauk SSSR 1983, 270, 1188-1192. (In Russian)

46. Men'shikov, Yu.P. Mineral Assemblages of Postmagmatic veins in Eveslogchorr Tectonic Zone of the Khibiny Massif. In Mineral Assemblages and Minerals of Magmatic Complexes of the Kola Peninsula: Apatity, Russia; Kola Branch of USSR Academy of Sciences: Apatity, Russia, 1987; pp. 49-54. (In Russian)

47. Men'shikov, Yu.P.; Pakhomovsky, Y.A.; Yakovenchuk, V.N. Beryllium mineralization within veins in Khibiny massif. Zap. Vseross. Mineral. Obs. 1999, 128, 3-14. (In Russian)

48. Merlino, S.; Biagioni, C.; Bonaccorsi, E.; Chukanov, N.V.; Pekov, I.V.; Krivovichev, S.V.; Armbruster, T. 'Clinobarylite'-barylite: OD relationships and nomenclature. Mineral. Mag. 2015, 79, 145-155. [CrossRef]

49. Chukanov, N.V.; Pekov, I.V.; Rastsvetaeva, R.K.; Chilov, G.V.; Zadov, A.E. Clinobarylite $\mathrm{BaBe}_{2} \mathrm{Si}_{2} \mathrm{O}_{7}-\mathrm{new}$ mineral from Khibiny massif, Kola Peninsula. Zap. Vser. Miner.Obshch. 2003, 132, 29-37. (In Russian)

50. Krivovichev, S.V.; Yakovenchuk, V.N.; Armbruster, T.; Mikhailova, Y.A.; Pakhomovsky, Y.A. Clinobarylite, $\mathrm{BaBe}_{2} \mathrm{Si}_{2} \mathrm{O}_{7}$ : Structure refinement, and revision of symmetry and physical properties. Neues Jb Miner. Monat. 2004, 8, 373-384. [CrossRef]

51. Gordienko, V.V. Mineralogy, Geochemistry and Genesis of Spodumene Pegmatites; Nedra: Leningrad, Russia, 1970; p. 240. (In Russian)

52. Lussier, A.J.; Hawthorne, F.C. Short-range constraints on chemical and structural variations in bavenite. Mineral. Mag. 2011, 75, 213-239. [CrossRef]

53. Schaller, W.T.; Fairchild, J.G. Bavenite, a beryllium mineral, pseudomorphous after beryl, from California. Am. Mineral. 1932, 17, 409-422. 
54. Lyalina, L.M.; Savchenko, Ye.E.; Selivanova, E.A.; Zozulya, D.R. Behoite and mimetite from the Saharjok alkaline pluton, Kola Peninsula. Geol. Ore Depos. 2010, 52, 641-645. [CrossRef]

55. Ehlmann, A.J.; Mitchell, R.S. Behoite, Beta-Be(OH) $)_{2}$, from the Rode Ranch Pegmatite, Llano County, Texas. Am. Miner. 1970, 55, 1-9.

56. Arzamastsev, A.; Yakovenchuk, V.; Pakhomovsky, Y.; Ivanyuk, G. The Khibina and Lovozero alkaline massifs: Geology and unique mineralization. In Proceedings of the Guidbook for 33rd International Geological Congress Excursion, Apatity, Russia, 22 July-2 August 2008; p. 58.

57. Pekov, I.V.; Chukanov, N.V.; Larsen, A.O.; Merlino, S.; Pasero, M.; Pushcharovsky, D.Yu.; Ivaldi, G.; Zadov, A.E.; Grishin, V.G.; Asheim, A.; et al. Sphaerobertrandite, $\mathrm{Be}_{3} \mathrm{SiO}_{4}(\mathrm{OH})_{2}$ : New data, crystal structure and genesis. Eur. J. Miner. 2003, 15, 157-166. [CrossRef]

58. Chemical Analyzes of Minerals; Kola Branch of USSR Academy of Sciences: Apatity, Russia, 1970; p. 508. (In Russian)

59. Sosedko, A.F. Materials on Mineralogy and Geochemistry of Granite Pegmatites; Gosgeotekhizdat: Moscow, Russia, 1961; 154p. (In Russian)

60. Vlasov, K.A.; Kuzmenko, M.V.; Es'kova, E.M. Lovozero Alkaline Massif; Izdatelstvo AN SSSR: Moscow, Russia, 1959; p. 632. (In Russian)

61. Semenov, E.I. Mineralogy of Lovozero Alkaline Massif; Nauka: Moscow, Russia, 1972; p. 307. (In Russian)

62. Pyatenko, Yu.A.; Bokii, G.B.; Belov, N.V. X-ray analysis of the crystal structure of chkalovite. Dokl. Akad. Nauk SSSR 1956, 108, 1077-1080. (In Russian)

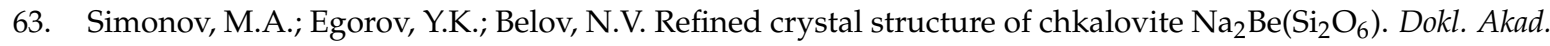
Nauk SSSR 1975, 225, 1319-1322. (In Russian)

64. Pekov, I.V. The Palitra pegmatite. Mineral. Rec. 2005, 36, 397-416.

65. Bussen, I.V.; Es'kova, E.M.; Men'shikov, Yu.P.; Mer'kov, A.N.; Sakharov, A.S.; Semenov, E.I.; Khomyakov, A.P. The Main Features of High Alkaline Pegmatites and Hydrothermalites. In Materialy po Mineralogii I Geokhimii Schelochnyx Kompleksov Porod Kol'skogo Poluostrova; Materials on Mineralogy and Geochemistry of Alkaline Rocks of the Kola Peninsula: Apatity, Russia, 1975; pp. 102-117. (In Russian)

66. Pakhomovsky, Y.A.; Yakovenchuk, V.N.; Ivanyuk, G.Yu.; Men'shikov, Yu.P. New Data on Mineralogy of "Sirenevaya" Pegmatite, Alluaiv Mnt.; Lovozero Masiif. In Proceedings of II Fersman Scientific Session of Russian Mineralogical Society; Woytekhovsky, Yu.L., Voloshin, A.V., Dudkin, O.B., Eds.; K \& M: Apatity, Russia, 2005; pp. 72-75. (In Russian)

67. Khomyakov, A.P.; Stepanov, V.I. The first finding of the chkalovite in Khibiny and its paragenesis. Dokl. Akad. Nauk SSSR 1979, 248, 727-730. (In Russian)

68. Tikhonenkova, R.P. Accessory chrysoberyl and monazite in the Khibiny massif. Dokl. Akad. Nauk SSSR 1982, 266, 1236-1239. (In Russian)

69. Belolipetsky, A.P.; Denisov, A.P.; Kulchitzkaya, E.A. Danalite Finding on the Kola Peninsula. In Materialy po Mineralogii Kolskogo Poluostrova. Vyp.4; Nauka: Leningrad, Russia, 1965; pp. 190-194. (In Russian)

70. Kalita, A.P. Pegmatites sand Hydrothermalites of Alkaline Granites of the Kola Peninsula; Nedra: Moscow, Russia, 1974; p. 140. (In Russian)

71. Pekov, I.V. Genetic Mineralogy and Crystal Chemistry of Rare Elements in Highly Alkaline Postmagmatic Systems. Ph.D. Thesis, Moscow State University, Moscow, Russia, 2005. (In Russian)

72. Sokolova, E.; Huminicki, D.M.C.; Hawthorne, F.C.; Agakhanov, A.A.; Pautov, L.A.; Grew, E.S. The crystal chemistry of telyushenkoite and leifite, $\mathrm{ANa}_{6}\left[\mathrm{Be}_{2} \mathrm{Al}_{3} \mathrm{Si}_{15} \mathrm{O}_{39} \mathrm{~F}_{2}\right], \mathrm{A}=\mathrm{Cs}$, Na. Can. Mineral. 2002, 40, $183-192$. [CrossRef]

73. Shilin, L.L.; Semenov, E.I. Beryllium minerals epididymite and eudidymite in alkali pegmatites of the Kola Peninsula. Dokl. Akad. Nauk SSSR 1957, 112, 325-328. (In Russian)

74. Sorokhtina, N.V.; Voloshin, A.V.; Pakhomovsky, Y.A.; Selivanova, E.A. The First Find of Daqingshanite-(Ce) on Kola Peninsula. In Proceedings of I Fersman Scientific Session of Russian Mineralogical Society; K \& M: Apatity, Russia, 2004; pp. 34-36. (In Russian)

75. Yakovenchuk, V.N.; Ivanyuk, G.Y.; Pakhomovsky, Y.A.; Selivanova, E.A.; Men'shikov, Yu.P.; Korchak, J.A.; Krivovichev, S.V.; Spiridonova, D.V.; Zalkind, O.A. Punkaruaivite, $\operatorname{LiTi}_{2}\left[\mathrm{Si}_{4} \mathrm{O}_{11}(\mathrm{OH})\right](\mathrm{OH})_{2} \cdot \mathrm{H}_{2} \mathrm{O}$, a new mineral species from hydrothermal assemblages, Khibiny and Lovozero Alkaline Massifs, Kola Peninsula, Russia. Can. Mineral. 2010, 48, 41-50. [CrossRef]

76. Khomyakov, A.P. The Mineralogy of the Ultra-Agpaitic Alkaline Rocks; Nauka: Moscow, Russia, 1990; p. 196. 
77. Tikhonenkov, I.P. Nepheline Syenites and Pegmatites of the Khibiny Massif and the Role of Postmagmatic Phenomena in Their Formation; Izdatelstvo AN SSSR: Moscow, Russia, 1963; 247p. (In Russian)

78. Fang, J.H.; Robinson, P.D.; Ohya, Y. Redetermination of the crystal structure of eudidymite and its dimorphic relationship to epididymite. Am. Mineral. 1972, 57, 1345-1354.

79. Gatta, D.G.; Rotiroti, N.; McIntyre, G.J.; Guastoni, A.; Nestola, F. New insights into the crystal chemistry of epididymite and eudidymite from Malosa, Malawi: A single-crystal neutron diffraction study. Am. Mineral. 2008, 93, 1158-1165. [CrossRef]

80. Pekov, I.V.; Chukanov, N.V.; Yamnova, N.A.; Zadov, A.E.; Tarassoff, P. Gjerdingenite-Na and gjerdingenite-Ca, two new mineral species the labuntsovite group. Can. Mineral. 2007, 45, 529-539. [CrossRef]

81. Belkov, I.V. Yttrium Mineralization of Amazonite Pegmatites of Alkaline Granites of the Kola Peninsula. In Voprosy Geologii I Mineralogii Kolskogo Poluostrova. Geology and Mineralogy of the Kola Peninsula. Vyp. 1; Izdatelstvo AN SSSR: Moscow, Russia, 1958; pp. 126-139. (In Russian)

82. Lunz, A.Y. About gadolinite nature from amazonite pegmatite. Zap. Vseross. Mineral. Obs. 1961, 90, 704-709. (In Russian)

83. Voloshin, A.V.; Pakhomovsky, Ya.A.; Sorokhtina, N.V. Study of the composition of gadolinite group minerals from amazonite randpegmatites of the Kola Peninsula. Vestnik MGTU 2002, 5, 61-70. (In Russian)

84. Belolipetsky, A.P.; Pletneva, N.I.; Denisov, A.P.; Kulchitzkaya, E.A. Accessory Gadolinite from Pegmatites and Granitic Viens on the Kola Peninsula. In Materialy po Mineralogii Kolskogo Poluostrova. Materials on Mineralogy of the Kola Peninsula. Vyp. 6; Nauka: Leningrad, Russia, 1968; pp. 162-173. (In Russian)

85. Lyalina, L.M.; Selivanova, E.A.; Savchenko, Y.E.; Zozulya, D.R.; Kadyrova, G.I. Minerals of the gadolinite-(Y)-hingganite-(Y) series in the alkali granite pegmatites of the Kola Peninsula. Geol. Ore Depos. 2014, 56, 675-684. [CrossRef]

86. Semenov, E.I. Mineralogy of Rare Earths; Izdatelstvo AN SSSR: Moscow, Russia, 1963; p. 412. (In Russian)

87. Voloshin, A.V.; Pakhomovsky, Ya.A. Minerals and Evolution of Mineral Formation in Amazonite Pegmatites of the Kola Peninsula; Nauka: Leningrad, Russia, 1986; p. 168. (In Russian)

88. Es'kova, E.M. Genthelvite from alkaline pegmatites. Dokl. Akad. Nauk SSSR 1957, 116, 481-483. (In Russian)

89. Vasil'ev, V.A. About genthelvite. Zap. Vseross. Mineral. Obs. 1961, 90, 571-578. (In Russian)

90. Lunz, A.Ya.; Sal'dau, E.P. Genthelvite from pegmatite on the Kola Peninsula. Zap. Vseross. Mineral. Obs. 1963, 92, 81-84. (In Russian)

91. Demartin, F.; Minaglia, A.; Gramaccioli, C.M. Characterization of gadolinite-group minerals using crystallographic data only; the case of higganite-(Y) from Cuasso Al Monte, Italy. Can. Miner. 2001, 39, 1105-1114. [CrossRef]

92. Shilin, L.L. Karpinskiite, a new mineral. Dokl. Akad. Nauk SSSR 1956, 107, 737-739. (In Russian)

93. Fleischer, M. New mineral names. Am. Miner. 1972, 57, 1003-1006.

94. Khomyakov, A.P.; Bykova, A.V.; Kaptsov, V.V. New Data on Lovozero Leifite. In New Data on Mineralogy of Alkali Formation Deposits; Trudy IMGRE: Moscow, Russia, 1979; pp. 12-15. (In Russian)

95. Pekov, I.V.; Nikolaev, A.P. Minerals of the pegmatites and hydrothermal assemblages of the Koashva deposit (Khibiny, Kola Peninsula, Russia). Mineral. Alm. 2013, 18, 7-65.

96. Semenov, E.I. Leucophan in alkali pegmatites of the Kola Peninsula. Trudy IMGRE 1957, 1, 60-63. (In Russian)

97. Lyalina, L.; Zozulya, D.; Selivanova, E.; Savchenko, Y. Rare beryllium silicates-meliphanite and leucophanite-from nepheline-feldspar pegmatite, Sakharjok massif, Kola Peninsula. In Proceedings of the XXXII International Conference Alkaline Magmatism of the Earth and Related Strategic Metal Deposits, Moscow, Russia, 7-14 August 2015; Kogarko, L.N., Ed.; GEOKHI RAS: Moscow, Russia, 2015; pp. 70-71.

98. Merlino, S. Lovdarite: Structural features and OD character. Eur. J. Mineral. 1990, 2, 809-817. [CrossRef]

99. Belkov, I.V.; Denisov, A.P. Melinofane from Sakharjok Alkaline Massif. In Materialy po Mineralogii Kolskogo Poluostrova, Materials on Mineralogy of the Kola Peninsula. Vyp. 6; Nauka: Leningrad, Russia, 1968; pp. 221-224. (In Russian)

100. Lyalina, L.M.; Kadyrova, G.I.; Selivanova, E.A; Zolotarev, A.A., Jr.; Savchenko, Y.E.; Panikorovskii, T.L. About composition of meliphanite of the nepheline syenite pegmatite of the Saharjok massif (Kola Peninsula). Zap. Vseross. Mineral. Obs. 2018, 2, 79-91. (In Russian) [CrossRef]

101. Grice, J.D.; Hawthorne, F.C. New data on meliphanite, $\mathrm{Ca}_{4}(\mathrm{Na}, \mathrm{Ca})_{4} \mathrm{Be}_{4} \mathrm{AlSi}_{7} \mathrm{O}_{24}(\mathrm{~F}, \mathrm{O})_{4}$. Can. Mineral. 2002, 40, 971-980. [CrossRef] 
102. Sosedko, T.A. The find of milarite on the Kola Peninsula. Dokl. Akad. Nauk SSSR 1960, 131, $643-647$. (In Russian)

103. Sosedko, T.A.; Telesheva, R.L. To the chemical composition of milarite. Dokl. Akad. Nauk SSSR 1962, 146, 437-439. (In Russian)

104. Palache, C. On the presence of beryllium in milarite. Am. Miner. 1931, 16, 469-470.

105. Pekov, I.V. Moraesite from alkaline pegmatite in Lovozero massif. Ural'skii Mineral. Sbornik 1995, 5, $256-260$. (In Russian)

106. Konev, A.A.; Vorob'ev, E.I.; Sapozhnikov, A.N.; Piskunova, L.F.; Uschapovskaya, Z.F. Odintsovite$\mathrm{K}_{2} \mathrm{Na}_{4} \mathrm{Ca}_{3} \mathrm{Ti}_{2} \mathrm{Be}_{4} \mathrm{Si}_{12} \mathrm{O}_{38}-$ new mineral (Murun massif). Zap. Vseross. Mineral. Obs. 1995, 5, 92-96. (In Russian)

107. Petersen, O.V.; Gault, R.A.; Balic-Zunic, T. Odintsovite from the Ilimaussaq alkaline complex, South Greenland. Neues Jahrb. Mineral. Monatshefte 2001, 5, 235-240.

108. Semenov, E.I. New hydrous beryllium silicates-gelbertrandite and sphaerobertrandite. Trudy IMGRE 1957, 1, 64-69. (In Russian)

109. Sørensen, H. Beryllium minerals in a pegmatite in the nepheline syenites of Ilimaussaq, South West Greenland. Internatl. GeoI. Congress, Rept. 21st Session, Norden. Am Mineral. 1960, 17, 31-35.

110. Fleischer, M. New Mineral Names. Am. Miner. 1961, 46, 241-244.

111. Fleischer, M. New Mineral Names. Am. Miner. 1963, 48, 1178-1184.

(C) 2018 by the authors. Licensee MDPI, Basel, Switzerland. This article is an open access article distributed under the terms and conditions of the Creative Commons Attribution (CC BY) license (http://creativecommons.org/licenses/by/4.0/). 